\title{
Sistema de Apoio Computacional à Criação de Canários de Cor
}

\author{
Rita de Cássia Gonçalves de Souza
}

Orientação: Prof. Dr. Marcos José Santana

Dissertação apresentada ao Instituto de Ciências Matemáticas e de Computação da Universidade de São Paulo - USP, como parte dos requisitos para a obtenção do título de Mestre em Ciências - Área de Ciências de Computação e Matemática Computacional.

\section{USP - São Carlos}

Abril/1998 
Aos meus pais,

Francisco e Joana, por tudo.

Ao Flávio, pelo apoio, dedicação e incentivo. 


\section{Agradecimentos}

Ao Prof. Dr. Marcos José Santana e à Profa. Dra. Regina Helena C. Santana, pela orientação, apoio e amizade;

Às Profas. Dra. Rosely Sanches e Dra. Solange Rezende, pela grande contribuição que deram a este trabalho, pela amizade e simpatia;

Aos meus irmãos Marcia e Osvaldo, pelo carinho e apoio;

Aos amigos do grupo de Sistemas Distribuídos e Programação Concorrente;

Ao CNPq pelo apoio financeiro;

À todos os professores e funcionários do Instituto, que contribuíram direta ou indiretamente durante o curso de mestrado. 


\section{Conteúdo}

Introdução

1.1 Considerações Iniciais

Sistemas Baseados em Conhecimento

2.1 Introdução

2.2 Estrutura Básica de um SBC

2.3 Conceitos Gerais de Sistemas Baseados em Conhecimento

9

2.4 Características de um Sistema Baseado em Conhecimento

2.5 Aquisição de Conhecimento

2.6 Desenvolvimento de um Sistema Baseado em Conhecimento

2.7 Linguagens, Shells e Ferramentas

2.8 Consideraçōes Finais 15

Canários de Cor

3.1 História

3.2 Evolução

3.3 A Genética dos Canários

3.3.1 Noçōes Básicas e Convenções Utilizadas

3.3.2 Os Fatores Enzima, Intenso e Nevado

3.3.3 A Cor de Fundo Amarela

3.3.4 A Cor de Fundo Branca

3.3.5 O Fator para Vermelho

3.3.6 O Canário Albino

3.3.7 A Mutação Canela

3.3.8 A Mutaçăo Ágata

3.3.9 O Canário Isabeliño

3.3.10 O Fator Marfim

3.3.11 O Fator Pastel

3.3.12 O Fator Opalino

3.3.13 O Fator Ino

3.3.14 O Fator para o Azul

3.3.15 O Fator Acetinado

3.3.16 O Fator Mosaico

3.3.17 O Canário Asa Cinza

3.3.18 O Canário Topázio

3.4 Considerações Finais

O Conhecimento Avançado________ 45

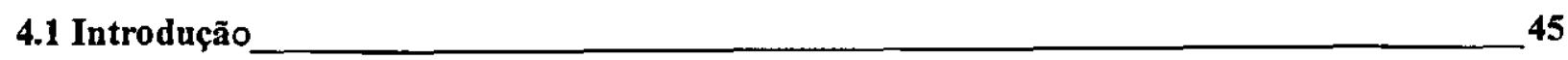

4.2 A Plumagem dos Canários ___ 45

4.3 Os Canários Brancos___ 48

4.4 Acasalamentos de Canários de Cor ___ 49

4.5 Consideraçōes Finais _ـ_ 50

Processo de Desenvolvimento do Sistema ___ 52

5.1 Introduçāo 
5.2 Análise de Requisitos 52

5.3 Especificação do Sub-sistema Acasalamentos 53

5.4 Projeto e Implementação do Sub-sistema Acasalamentos 58

5.5 Fórmulas Genéticas 61

5.6 Processo de Combinação de Genótipos 62

5.7 Considerações Finais 63

Aconselhamentos 64

6.1 Introdução 64

6.2 Fases do Desenvolvimento 64

6.2.1 Identificaçăo do Dominio

6.2.2 Aquisição de Conhecimento

6.2.3 Implementaçăo do Módulo de Aconselhamentos

6.2.4 Validaçăo e Refinamento do sistema

6.3 Considerações Finais 74

Exemplo do Funcionamento do Sistema de Apoio à Criação de Canários de Cor75

7.1 Introdução 75 Conclusões 84

8.1 Consideraçōes Iniciais 84

8.2 Conclusões 84

8.3 Contribuiçōes deste Trabalho 86

8.4 Trabalhos Futuros 87

APÊNDICE A 89

Glossário 89

APÊNDICE B 96

A Linha Clara 96

A Linha Escura 97

Nomenclatura Oficial O.B.J.O. - Canários de Cor 101 Referências Bibliográficas 106 
Figura 2.I - Estrutura básica de um SBC [ROD93].

Figura 2.2 - Sistema Especialista e SBC [ROD93].

Figura 2.3 - Conceito básico da função de um SBC [GIA94].

Figura 2.4 - Relação entre um possivel problema e o dominio do conhecimento [GIA94].

Figura 2.5 - Desenvolvimento de um SBC [GIA94].

Quadro 2.1 - Atividades de um EC no desenvolvimento de um sistema [ROD93].

Figura 2.6 - Modalidades de Aquisição de Conhecimento [ROD93].

Figura 2.7 - Estágios do Desenvolvimento de um SBC [ROD93].

Figura 3.1 - Exemplo simplificado do processo de meiose [SIL87].

Figura 3.2 - Recombinação ou Crossing-over [OBJ96]

Figura 3.3 - Segregação Independente, com dois pares de cromossomos [SIL87].

Figura 3.4 - Relação dos genes autossomais e sexo-ligados e seus mutantes [OBJ96].

Figura 3.5 - Genótipos gerados durante a meiose no acasalamento de ágata com canela [SIL87]. __ 36

Figura 3.6 - Cruzamentos de macho acetinado com tipos diferentes de femeas [SIL87].

Quadro 4.l - Areas de atuação do lipocromo em Mosaicos [SE196c].

Figura 4.I - Pássaros com ótima extensão das zonas de eleição dos lipocromos [OBJ96].

Quadro 4.2 - Diretrizes para acasalamento [NEI92].

Figura S.l - Tela de Apresentação do sistema

Quadro 5.l - Descrição das tabelas do Sistema de Apoio à Criação de Canários de Cor.

Figura 5.2 - Relacionamento entre as tabelas do sub-sistema Acasalamentos.

Figura 5.3-DFD de nivel 0

Figura 5.4 - Diagrama de Fluxo de Dados do "Sistema de Apoio à Criação de Canários de Cor"

Figura 5.5 - Cadastro de Cores

Figura 5.6-Consulta ao Cadastro de Cores

Figura 5.7-Acasalamentos

Figura 5.8 - Alteração de Genótipos através de informações adicionais __ 60

Figura 5.9-Resultados do Acasalamento

Figura 6.l(a) - Esquema de perguntas do módulo de Aconselhamentos _ 67

Figura 6.1 (b) - Esquema de perguntas do módulo de Aconselhamentos (continuação) ___ 68

Figura 6.2 (a) - Algumas regras que compóem a Base de Conhecimento do módulo de Aconselhamentos__ 69

Figura 6.2 (b) - Algumas regras que compõem a Base de Conhecimento do módulo de Aconselhamentos

(continuação)

Figura 6.3 (a) - Janelas do módulo de Aconselhamentos.

Figura 6.3 (b) - Janelas do módulo de Aconselhamentos (continuação). ___ 73

Figura A-I - Genes alelos [EPM97].

Figura A-2 - Exemplificação de homozigoto e heterozigoto [EPM97].

Figura A-3 - Exemplificação de locus [EPM97].

Figura A-4 - Topografia do Canário [MAT92].

Figura A-5 - Estrutura das penas [SIL87].

Figura A-6 - Estrias [SIL87].

Figura B-l - Exemplos de canários da linha clara [KEU].

Figura B-2 - Exemplos de canários da linha escura [KEU].

Figura B-3 - Pássaros Tarim e o Canário Selvagem [WAL87]. 


\section{Resumo}

A área de computação oferece uma variedade de técnicas e ferramentas com o objetivo de auxiliar na resolução de problemas de diversas áreas de aplicação.

O sucesso de um projeto depende muitas vezes da escolha correta dessas ferramentas e das técnicas que serão utilizadas durante as fases do desenvolvimento. Além disso, é importante conhecer previamente as expectativas do usuário e qual seu grau de familiarização com o uso de sistemas informatizados.

Esta dissertação de mestrado aborda a utilização de diferentes técnicas e ferramentas de programação na solução de um problema específico - o acasalamento de canários de cor. $O$ trabalho apresenta um levantamento detalhado da evolução dos canários, da sua descoberta até a última mutação registrada envolvendo os genes responsáveis pela cor da plumagem.

Para uma melhor compreensão do assunto, é apresentada uma pequena revisão sobre genética e sobre o conhecimento de especialistas da área de canaricultura de cor.

Para solucionar o problema, são considerados neste trabalho a utilização de diferentes métodos de desenvolvimento propostos por duas grandes áreas: a Engenharia de Software e a Inteligência Artificial. As técnicas estudadas são implementadas, integrando um Sistema Baseado em Conhecimento e a programação convencional num único sistema. O resultado obtido demonstra que pode-se obter uma solução mais adequada ao problema quando diferentes métodos são combinados. 


\section{Abstract}

The computing area offers a variety of techniques and tools with the objective of helping the resolution of problems from several applications areas.

The success of a design depends many times on the correct choice of these tools and techniques which will be used during the phases of development. Moreover, it is important to know previously the expectation of the user and how is his degree of familiarization with the use of information systems.

This MSc dissertation approaches the use of different techniques and programming tools in the solution of a specific problem - the colored canaries breeding. The work presents a detailed survey of the evolution of the canaries, since its discovery until the last registered mutation involving the responsible genes for the colour of the plumage.

For better understanding, the dissertation presents a short revision about genetics and specialists knowledge about coloured canaries.

To solve the problem, this work considers the use of different methods of development from two wide areas: Software Engineering and Artificial Intelligence. The studied techniques are implemented, integrating Knowledge Based System and conventional programming in the same system. The final results demonstrate that a better solution for a given problem can be achieved by combining different methods. 


\section{Introdução}

\subsection{Considerações Iniciais}

O interesse pela criação de canários de cor teve início no começo deste século, com a primeira mutação que deu origem à cor Ágata, a partir do acasalamento de pássaros verdes. Desde então, o interesse pela criação de canários de cor vem crescendo visivelmente. Os canaricultures vêm tentando deixar de lado a criação por simples hobby para se tornarem profissionais nesse ramo. A criação de canários envolve um volume muito grande de recursos, constituído de acessórios, alimentação, além da comercialização das próprias aves, movimentando milhões de dólares no mercado mundial.

No princípio, a grande maioria de canaricultores possuía plantéis com poucos casais, conseguindo manter total controle sobre todos os cuidados que a atividade requer. No entanto, para se obter bons resultados através de acasalamentos, é necessário aumentar significativamente o número de pássaros, o que torna impossível o controle manual, fazendo com que os criadores busquem na informática o auxílio necessário.

Em um levantamento realizado em publicações e pesquisas feitas na Internet foi possível encontrar alguns sistemas para apoio à criação de pássaros em geral. No entanto, a maioria deles se restringe a sistemas baseados em banco de dados, constituídos de cadastros, registros de acasalamentos, controle veterinário, etc., necessários para a manutenção de plantéis. É importante haver um sistema que contenha informações que auxiliem na seleção dos melhores exemplares para acasalamento, levando em consideração a genética e diversos outros conhecimentos necessários para se obter filhotes de qualidade, que apresente uma interface amigável e possa ser integrado com um sistema de banco de dados.

Tais necessidades podem ser resolvidas com a utilização de um Sistema Baseado em Conhecimento, cujo papel principal é reter o domínio do conhecimento do especialista, a fim de disponibilizá-lo àqueles que não o possuem com o mesmo grau de entendimento. Através de sistemas desse tipo, muitas pessoas podem receber os beneficios da experiência de especialistas quando confrontadas com problemas similares. Quando questionado sobre fatos específicos, o Sistema Baseado em Conhecimento fornece uma solução e o raciocínio que utilizou para chegar 
àquela decisão. Com isso, o computador provê o usuário com o processo conceitual de um especialista e o ajuda a tomar uma decisão.

Um sistema baseado em conhecimento poderia responder a questões do tipo:

- Que casais devem ser utilizados para se obter determinada cor.

- Quais os resultados obtidos através do acasalamento de determinado casal.

- Na existência de um bom exemplar, qual o melhor par para o acasalamento.

- O que aconteceria se fossem acasalados canários com determinadas características.

- Que tipos de acasalamentos devem ser evitados, ou por serem letais, ou porque podem colocar em risco gerações futuras.

As atividades desenvolvidas neste trabalho abrangem:

- Levantamento bibliográfico sobre as informações existentes sobre acasalamentos de canários de cor, desde fórmulas genéticas até o conhecimento adquirido pela prática de criação, mas que influenciam diretamente na melhoria da espécie.

- Entrevistas com especialistas em canaricultura de cor, cuja experiência de vários anos se transformou em grande fonte de conhecimento a respeito do assunto.

- Aplicação de técnicas e metodologias das áreas de Inteligência Artificial e Engenharia de Software.

- Projeto e implementação de uma Base de Conhecimento e de uma Base de Dados.

- Criação de uma interface amigável e um banco de imagens com a finalidade de facilitar a pesquisa pelo usuário.

- Testes e refinamentos do sistema desenvolvido.

Esta dissertação está organizada em 8 capítulos:

- O capítulo 2 trata dos Sistemas Baseados em Conhecimento (SBC), apresentando os principais conceitos, estrutura básica, características, formas de aquisição de conhecimento, estágios de desenvolvimento de um SBC e algumas aplicações.

- O capítulo 3 fala da evolução dos canários de cor, desde a sua "descoberta" até os dias de hoje, incluindo as mutações genéticas ocorridas, além de algumas explicações básicas sobre genética, necessárias para se entender todo o processo. As palavras que aparecem em negrito neste capítulo são explicadas no apêndice $\mathrm{A}$. 
- O capítulo 4 trata do que se pode chamar de Conhecimento Avançado sobre a criação de canários de cor. São alguns exemplos de informações importantes sobre os cuidados que se deve ter durante o acasalamento dos canários, a fim de se obter filhotes de qualidade e competitivos em concursos.

- O capítulo 5 apresenta o módulo de Acasalamentos, desenvolvido através de técnicas de Engenharia de Software.

- No capítulo 6 são descritas as fases do desenvolvimento do módulo de Aconselhamentos, baseado em técnicas de Inteligência Artificial.

- O capítulo 7 traz um exemplo do funcionamento do software, contendo a seqüência das telas e explicações.

- O capítulo 8 finaliza este trabalho, apresentando as conclusões e considerações finais.

- O apêndice A traz um glossário dos termos genéticos e a topografia do canário, utilizados neste trabalho, principalmente no capítulo 3 .

- Finalmente, no apêndice B se encontram informações para esclarecimento sobre as cores dos canários, linha clara e linha escura, com ilustrações, além da tabela de nomenclatura oficial da Ordem Brasileira de Juizes de Ornitologia. 


\section{Sistemas Baseados em Conhecimento}

\subsection{Introdução}

A noção básica que está por trás de um Sistema Baseado em Conhecimento, SBC, é a captura do conhecimento humano para solucionar problemas em áreas bastante restritas. Uma vez que o conhecimento do especialista é registrado em um computador, esse conhecimento deve ser representado de tal forma que a máquina possa se aproximar da habilidade do especialista para resolver uma classe particular de problemas. Um SBC retém o domínio do conhecimento do especialista para torná-lo disponível àqueles que não o possuem com o mesmo grau de entendimento. Através da retenção do conhecimento de um especialista dentro de um programa de computador, muitas pessoas recebem os benefícios da experiência de especialistas quando confrontados com problemas similares. Quando questionado sobre fatos específicos, o SBC fomece uma solução e o raciocínio que utilizou para chegar àquela decisão. $O$ computador provê o usuário com o processo conceitual de um especialista e o ajuda a tomar uma decisão.

Sistemas Baseados em Conhecimento é um ramo de Inteligência Artificial que abrange vários itens, tais como: Sistemas Especialistas, Sistemas de Visão, Sistemas de Linguagem Natural, entre outros. [CLE88][RAG92].

Os Sistemas Baseados em Conhecimento podem ser definidos como "programas de computador que utilizam conhecimento representado explicitamente para resolver problemas". Os principais pontos no desenvolvimento de um SBC são o conhecimento e o processo de resolução de problemas [ROD93].

Os Sistemas Baseados em Conhecimento devem considerar dois tipos de operações, utilizadas pelo ser humano na resolução de problemas [ROD93]:

- A capacidade de raciocínio, denominada estratégia de raciocínio ou ainda estratégia de inferência, ou seja, como o ser humano chega a certas conclusões ou gera novos conhecimentos, através da interpretação do conhecimento adquirido.

- A metodologia para a resolução de problemas, isto é, a capacidade de resolver problemas de forma rápida e clara, através da condução do processo de raciocínio de forma que apenas as conclusões relevantes ao problema em questão sejam inferidas. 
Assim, além da base de conhecimento necessária a um SBC, também é importante considerar um outro tipo de conhecimento: as metodologias que devem ser utilizadas para a resolução de problemas. Essas metodologias são técnicas de inferência utilizadas pelo ser humano, a fim de alcançar um objetivo. Contudo, essas técnicas ou estratégias para resolução de problemas constituem somente uma parte do conhecimento implícito na metodologia para resolução de problemas. No ser humano, as estratégias para resolução de problemas são combinadas com heurísticas, que são regras práticas que ajudam a reduzir o esforço de busca por soluções. Uma heurística é completamente diferente de um algoritmo. Os algoritmos devem ser infalíveis, formecendo sempre respostas precisas. Já as heurísticas geralmente acertam, mas podem passar por caminhos desnecessários. É justamente a qualidade das heurísticas utilizadas que diferencia a capacidade das pessoas para resolver problemas [ROD93][RAG92].

\subsection{Estrutura Básica de um SBC}

Os Sistemas Baseados em Conhecimento podem ser divididos da seguinte forma [KBS94][ROD93]:

1. A Base de Conhecimento, contendo a realidade do especialista, ou seja, a modelagem do conhecimento específico do domínio de aplicação, incluindo asserções sobre o domínio de conhecimento, as regras que descrevem relações nesse domínio, podendo fazer parte, também. heurísticas e métodos de resolução de problemas nesse domínio.

2. O Motor de Inferência, um software de propósito geral que contém as instruções necessárias para que o computador possa raciocinar, utilizando as informações contidas na base de conhecimento. Essas instruções são as estratégias de inferência e de controle. Quando o conhecimento é expresso em regras de produção dentro da base de conhecimento, as estratégias de controle normalmente usadas pelo motor de inferência podem ser Backward Chaining (encadeamento regressivo) ou Forward Chaining (encadeamento progressivo). Na estratégia Backward Chaining, a meta é o ponto de partida e o sistema deve buscar fatos e regras que a comprovem ou não. Esta estratégia corresponde à pergunta: "É possível provar as hipóteses a partir dos dados que se tem?". Na estratégia Forward Chaining, o computador parte dos dados informados e, com base nas regras de conhecimento, deduz outras asserções

\footnotetext{
- O conhecimento pode ser representado também através de frames, scripts, redes semânticas além de outras formas. Neste trabalho, o conhecimento será representado por regras de produção, do tipo SE ENTÃO (IF THEN).
} 
até chegar à solução do problema. Corresponde à: "O que é possível concluir a partir dos dados que se tem?"”.

3. O Grupo de Interfaces, que conectam o motor de inferência ao usuário, aos bancos de dados externos ou a outros computadores ou programas de computadores. Deve oferecer, também, justificativas para a solução encontrada.

Os SBCs retém informações disponiveis e relevantes que o motor de inferência utiliza para transformá-las em conhecimento e usar este conhecimento para tomar uma decisão. Ou seja, o sistema utiliza fatos de várias fontes de dados (inclusive do usuário) e produz conselhos e recomendações baseados em regras contidos em sua base de conhecimento, explicando e justificando os resultados encontrados [KBS94]. Geralmente, a explicação é baseada no caminho percorrido pela informação durante o curso de uma consulta ao sistema, mostrando quais regras foram disparadas e em que momento. No entanto, mostrar simplesmente o caminho percorrido não é a melhor forma. $O$ sistema deve oferecer explicações em um formato mais próximo à linguagem do usuário [RAG92]. A figura 2.1 mostra os três módulos que compõem um SBC.

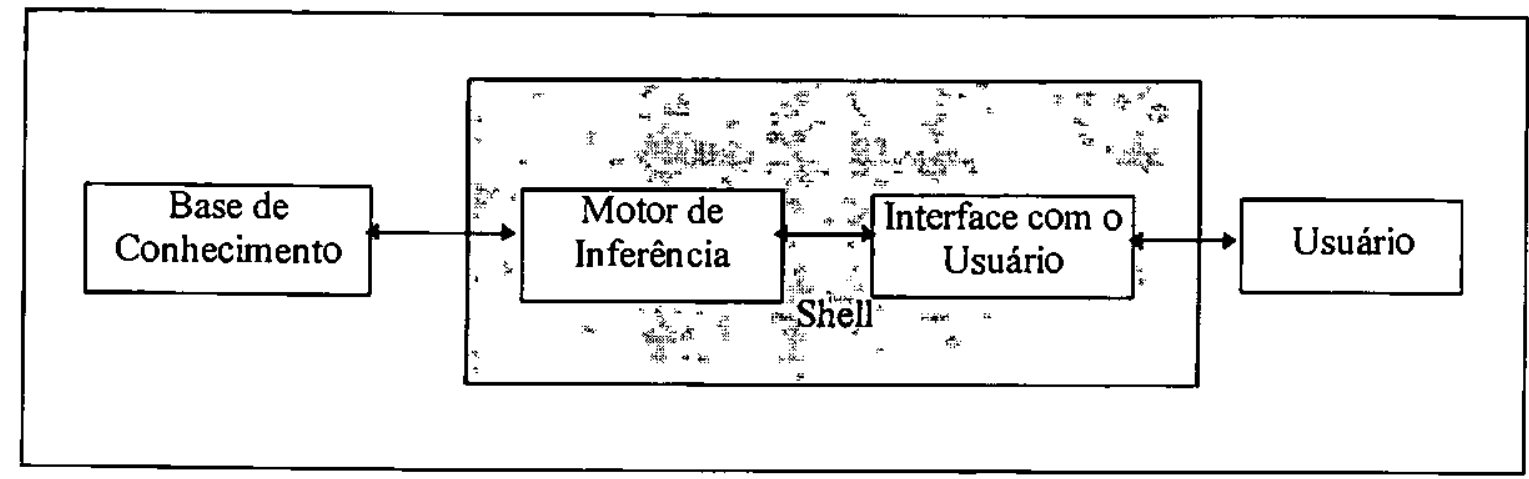

Figura 2.1 - Estrutura básica de um SBC [ROD93].

A Shell denomina uma classe de software cuja função é auxiliar o processo de construção de Sistemas Baseados em Conhecimento. Esses softwares podem reduzir de forma considerável o custo de um projeto de SBC. Uma Shell é um módulo composto pelo Motor de Inferência e a Interface com o Usuário [ROD93].

Embora seja possível escrever um SBC utilizando uma linguagem de programação, isto não é necessário. Uma Shell fornece ferramentas para a construção de SBCs simples, para domínios apropriados. Ela fornece ao programador um meio de representação do conhecimento. Há muitas técnicas para se fazer isso, sendo a mais conhecida a regra de produção. Adotada por ser uma das representações mais "naturais" e a menos técnica, as regras de produção são escritas num formato bem próximo à linguagem humana [RAG92]. 
Os Sistemas Especialistas constituem uma classe especifica dos Sistemas Baseados em Conhecimento. São programas capazes de resolver problemas complexos, normalmente resolvidos por especialistas, com alto nível de habilidade. A figura 2.2 descreve as características desses sistemas no contexto dos sistemas de Inteligência Artificial [ROD93].

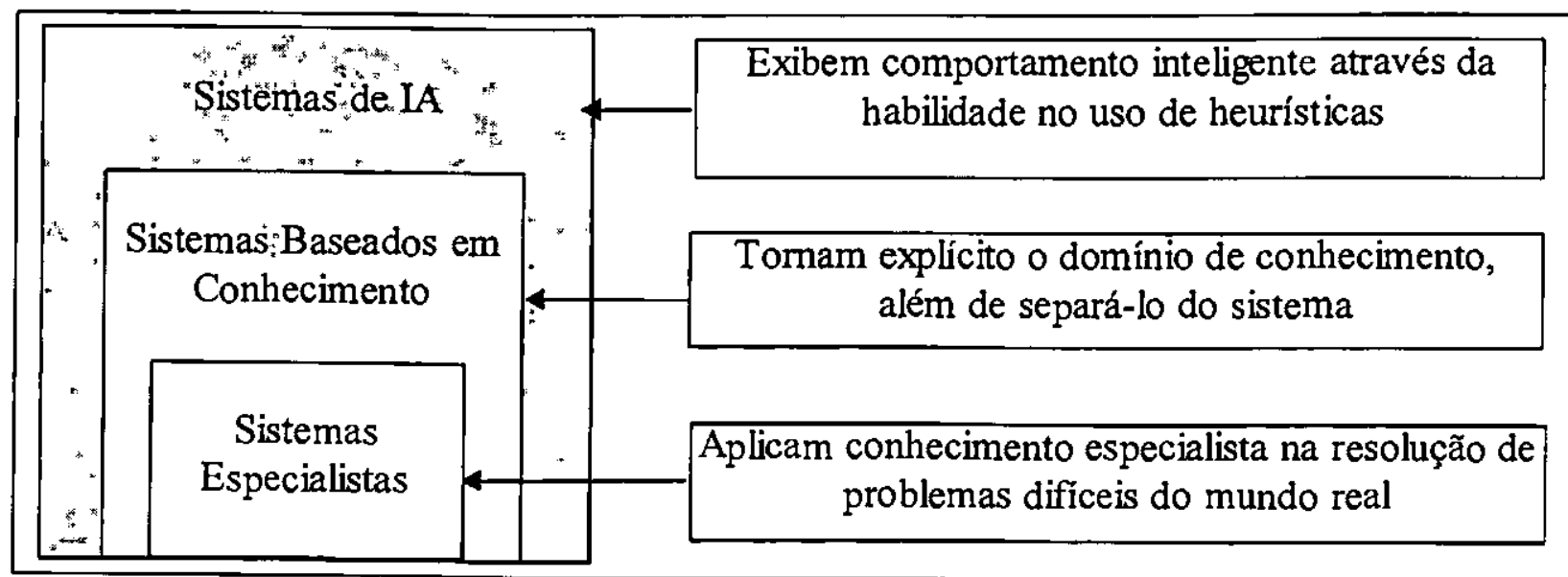

Figura 2.2 - Sistema Especialista e SBC [ROD93].

Um Sistema Especialista, SE, pode ser definido como “... um programa de computador inteligente que utiliza conhecimento e métodos de inferência para resolver problemas tão dificeis que requerem um especialista para encontrar a solução.", ou ainda, "um sistema de computador que emula a habilidade que possui um especialista humano para tomar decisões" [GIA94].

O conhecimento em sistemas especialistas pode ser obtido tanto de um especialista, como através de livros, revistas e pessoas com algum conhecimento do assunto. Os termos Sistema Especialista, Sistema Baseado em Conhecimento ou Sistema Especialista Baseado em Conhecimento são freqüentemente usados como sinônimos [GIA94]. Neste trabalho será utilizado o termo Sistemas Baseados em Conhecimento ou simplesmente SBC.

Um Sistema Baseado em Conhecimento é aquele que resolve problemas utilizando o conhecimento sobre o domínio do problema. Já um Sistema Especialista é um Sistema Baseado em Conhecimento que resolve problemas da vida real que, para serem resolvidos pelo ser humano, requerem considerável habilidade, conhecimento e heurísticas [ROD93].

A figura 2.3 ilustra o conceito básico de um SBC. O usuário fornece fatos ou uma informação qualquer ao $\mathrm{SBC}$ e recebe em resposta um conselho ou informação especializada. Internamente, o SBC consiste de dois componentes principais: a base de conhecimento e o motor de inferência, que utiliza o conhecimento contido na base de conhecimento para chegar a 
algumas conclusões. Estas conclusões são as respostas do SBC às questões colocadas pelo usuário [GIA94].

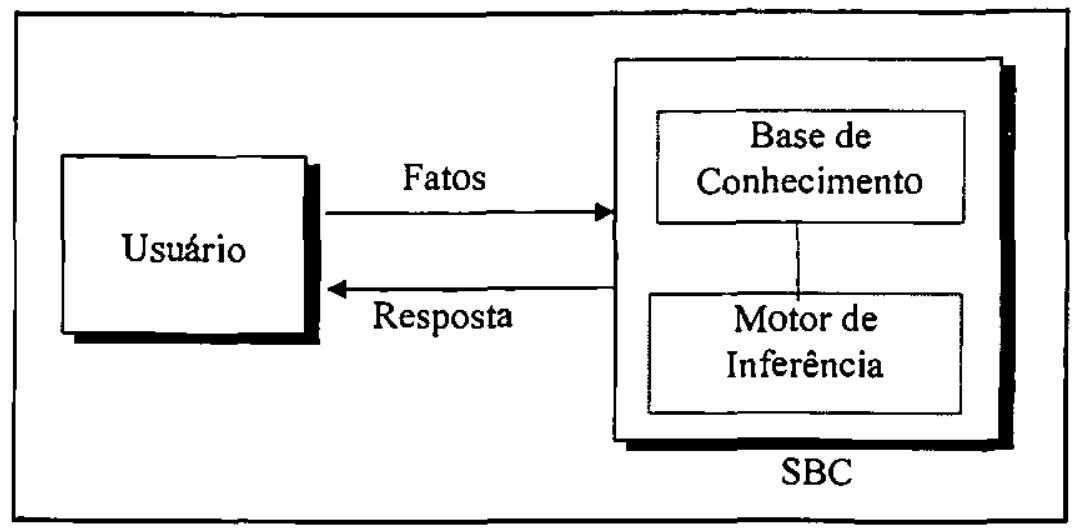

Figura 2.3 - Conceito básico da função de um SBC [GIA94].

O conhecimento de um especialista é específico a um domínio de problema, ou seja, a uma área especial, como a medicina, finanças, engenharia e assim por diante, onde o especialista pode resolver os problemas de forma eficiente. $O$ conhecimento que um especialista possui para resolver problemas específicos é chamado domínio de conhecimento do especialista. Os SBCs, assim como o especialista humano, são geralmente projetados para serem especialistas em um domínio do conhecimento Por exemplo, um SBC da área de medicina, projetado para diagnosticar doenças infecciosas, terá uma grande quantidade de conhecimento sobre certos sintomas causados por tais doenças. Neste caso, o domínio do conhecimento é a medicina e consiste de conhecimento sobre doenças, sintomas e tratamentos. A figura 2.4 ilustra o relacionamento entre o problema e o domínio do conhecimento, onde é possível observar que o domínio do conhecimento está inserido completamente dentro do domínio do problema [GIA94].

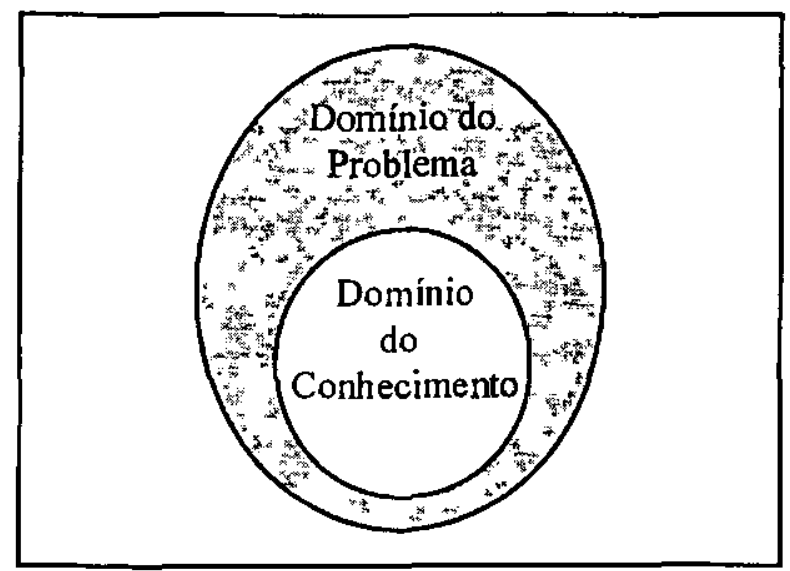

Figura 2.4 - Relação entre um possivel problema e o domínio do conhecimento [GIA94]. 
Dentro do domínio de conhecimento, o SBC raciocina ou faz inferências da mesma forma que um especialista humano faria para solucionar um problema, ou seja, diante de alguns fatos, uma conclusão pode ser inferida [GIA94].

\subsection{Conceitos Gerais de Sistemas Baseados em Conhecimento}

Muitas vezes o conhecimento deve ser extraído de um especialista através de sessões de aquisição de conhecimento feitas por um Engenheiro do Conhecimento (EC). O processo de construção de um SBC é denominado Engenharia de Conhecimento, feita por um Engenheiro de Conhecimento. A Engenharia de Conhecimento se refere à aquisição de conhecimento de um especialista humano ou outra fonte e sua codificação no sistema especialista [GIA94].

A figura 2.5 mostra de forma simplificada os passos para o desenvolvimento de um SBC. O Engenheiro de Conhecimento primeiro estabelece um diálogo com o especialista humano, a fim de extrair o conhecimento do especialista. Esse estágio é análogo ao projeto de um sistema convencional, onde são discutidas as necessidades do sistema com o cliente para o qual o sistema está sendo desenvolvido. O Engenheiro de Conhecimento codifica, então, o conhecimento explicitamente na base de conhecimento. O especialista avalia e critica o SBC. Este processo se repete até que o desempenho do sistema se torne satisfatório ao especialista [GIA94].

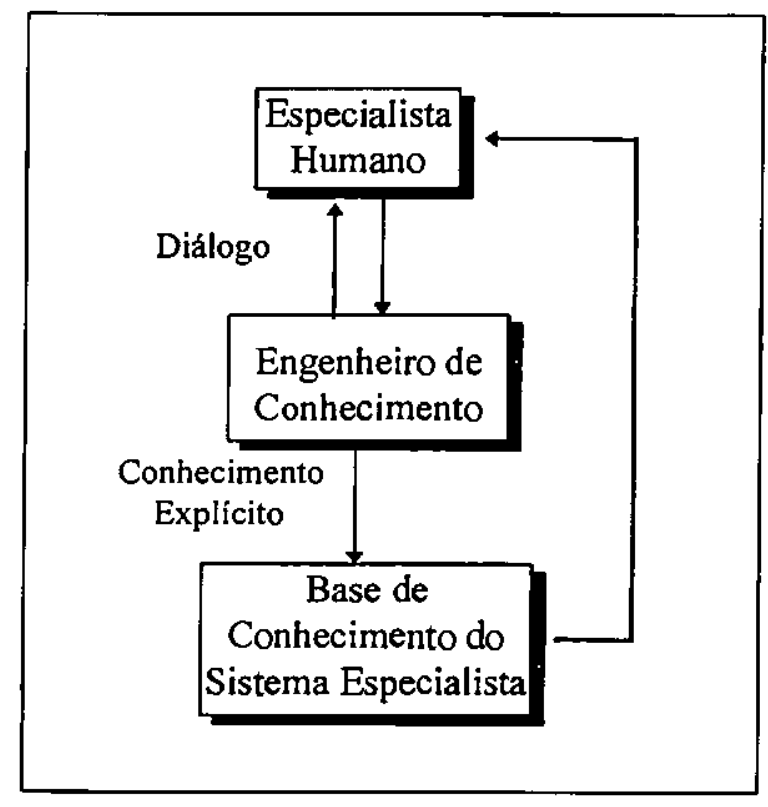

Figura 2.5 - Desenvolvimento de um SBC [GIA94]. 
O quadro 2.1 apresenta as atividades de um Engenheiro de Conhecimento no desenvolvimento de um sistema.

\begin{tabular}{|l|l|}
\hline Atividades do EC & Produtos Obtidos \\
\hline Aquisição de Conhecimento & $\begin{array}{l}\text { Domínio do conhecimento } \\
\text { Regras heurísticas }\end{array}$ \\
Projeto do SBC & $\begin{array}{l}\text { Esquema de representação de conhecimento } \\
\text { Motor de inferência } \\
\text { Estratégia de resolução do problema } \\
\text { Modelagem de Conhecimento } \\
\text { Refinamento do Conhecimento Conhecimento }\end{array}$ \\
& $\begin{array}{l}\text { Belhoria das regras heurísticas } \\
\text { Revisão do domínio de conhecimento }\end{array}$ \\
\hline
\end{tabular}

Quadro 2.1 - Atividades de um EC no desenvolvimento de um sistema [ROD93].

Os SBCs geralmente são projetados de forma diferente dos programas convencionais, porque os problemas normalmente não têm solução algorítmica e confiam em inferências para obter uma solução razoável. Em alguns casos, uma solução razoável é a melhor que se pode esperar se nenhum algoritmo está disponível para ajudar a obter uma solução ótima. Uma vez que um SBC utiliza inferências dentro de uma Base de Conhecimento, ele deve ser capaz de explicar seu raciocínio para que este possa ser checado. A facilidade de uma explicação é parte integrante de SBCs sofisticados [GIA94].

\subsection{Características de um Sistema Baseado em Conhecimento}

Um SBC é normalmente projetado para ter as seguintes características [GIA94]:

- Alto desempenho - o sistema deve ser capaz de responder a um nivel de competência igual ou melhor do que um especialista da área.

- Tempo de resposta adequado - O sistema deve executar dentro de um tempo razoável, comparável ou melhor que o tempo necessário para um especialista encontrar uma solução.

- Boa confiabilidade - o SBC deve ser confiável e não propenso a falhas.

- Compreensível - O sistema deve ser capaz de explicar os passos de seu raciocínio, assim como um especialista. Essa característica é muito importante em um sistema, por pelo menos 2 razões:

- A vida ou os direitos de um ser humano, por exemplo, podem depender das respostas de um sistema especialista. Assim, o sistema deve ser capaz de justificar suas conclusões da mesma forma que um especialista humano. 
- As explicações dadas pelo SBC facilitam a correção de erros durante a fase do seu desenvolvimento. Isso evita que haja algum mal-entendido entre o especialista e o Engenheiro de Conhecimento.

- Flexibilidade - é importante que o sistema tenha um mecanismo eficiente para que o conhecimento possa ser alterado, excluido ou para que novos conhecimentos possam ser adicionados.

\subsection{Aquisição de Conhecimento}

"A aquisição de conhecimento consiste na extração do conhecimento do especialista no dominio, bem como na incorporação deste conhecimento em um sistema de raciocínio automático capaz de resolver o mesmo tipo de problema que o especialista humano resolve" [ROD93].

Um problema que ocorre em SBCs atualmente é que a especialidade do sistema está limitada ao domínio do conhecimento que o sistema possui. SBCs típicos não podem generalizar seu conhecimento pelo uso de analogias para raciocinar sobre novas situações, da mesma forma que o ser humano pode fazer. A forma normal de um Engenheiro de Conhecimento construir um Sistema Baseado em Conhecimento é através da repetição do ciclo de aquisição de conhecimento, construção de protótipos, testes, entrevistas e assim por diante. Este é um trabalho intenso, que consome muito tempo. De fato, a aquisição de conhecimento é considerada o "gargalo" da construção de um Sistema Baseado em Conhecimento [GIA94].

Há diferentes modalidades de Aquisição de Conhecimento. A primeira delas, e a mais utilizada, é aquela realizada por intermédio do Engenheiro de Conhecimento. Alguns fatores como dados incompletos ou inconsistências causadas por integração de dados provenientes de várias fontes complicam esta abordagem. Uma segunda alternativa é a aquisição em que o próprio especialista coloca o conhecimento no sistema, utilizando um programa de edição que facilita a manipulação do conteúdo da Base de Conhecimento. Para que isso seja possivel, é necessário que o Motor de Inferência seja fixo e a estrutura da Base de Conhecimento seja prédefinida e de fácil compreensão pelo especialista. A terceira modalidade é a Indução de Conhecimento, onde um programa de computador examina os dados de entrada e gera regras de conhecimento que podem ser usadas na Base de Conhecimento do SBC. Essa forma de aquisição de conhecimento é possível quando há grande quantidade de dados disponíveis. A quarta, e última modalidade, é denominada Programa de Aprendizagem. Um programa de computador é alimentado por textos, exemplos ou aconselhamentos de um especialista e gera ou refina o 
conhecimento com base nessa interação [ROD93]. As quatro modalidades são ilustradas na figura 2.6.

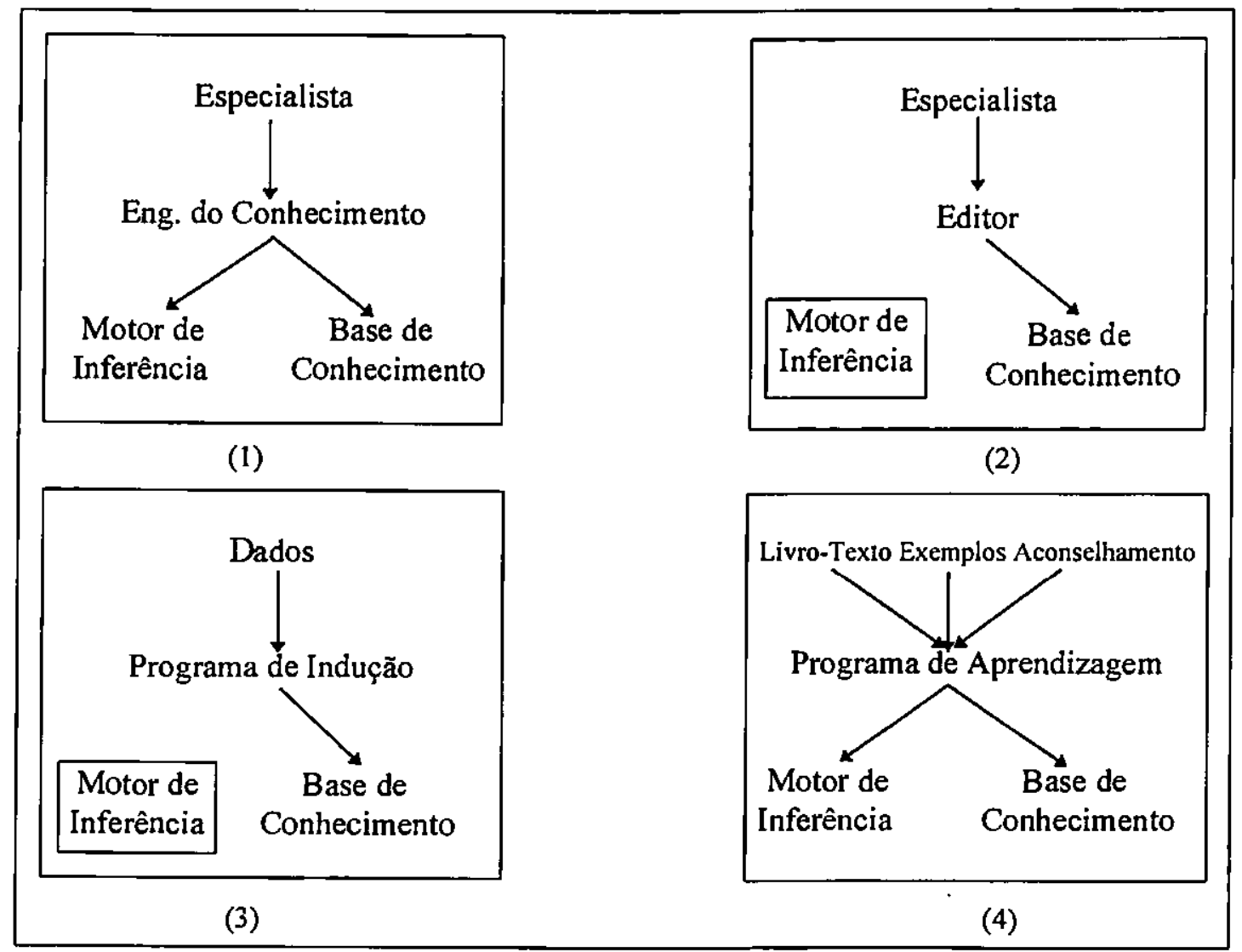

Figura 2.6 - Modalidades de Aquisição de Conhecimento [ROD93].

A aquisição de conhecimento é considerada a chave para o sucesso no desenvolvimento de SBCs. Se um SBC está sendo construído e usado com sucesso, então a aquisição de conhecimento está sendo empregada também com sucesso [CLE88].

$O$ problema de aquisição de conhecimento é um dos mais difíceis em Inteligência Artificial. Muitas vezes o especialista sabe resolver o problema mas dificilmente sabe explicar como o resolveu. Por outro lado, o Engenheiro do Conhecimento sabe bem as técnicas de representar o conhecimento mas não consegue, mesmo conhecendo as técnicas de aquisição. como abordar o especialista e como manter um interesse permanente desses especialistas. Uma forma de resolver o problema da aquisição de conhecimento do especialista é o estabelecimento de técnicas, como entrevistas, construção de exemplos, etc. As duas técnicas mais utilizadas para entrevistas são:

- Entrevista Aberta - deve ser realizada na primeira reunião e toda vez que se fizer necessário com a participação do especialista. Caso o usuário esteja no grupo, solicitar que ele descreva 
o que espera do sistema. Posteriormente deverá ser feita uma entrevista com o especialista. Esta técnica tenta atingir os seguintes objetivos:

- estabelecer um entendimento entre os elementos do grupo

- fazer com que o problema seja esclarecido

- encorajar o especialista a colocar suas idéias, usando os recursos que ele achar melhor - Entrevista Focalizada - tem como objetivos aprofundar o conhecimento e extrair o conhecimento específico. Para isso, podem-se utilizar algumas técnicas como:

- fazer questões objetivas - questionários do tipo sim ou não

- detectar os pontos importantes e pedir explicaçōes

- ouvir ou gravar o especialista quando ele resolve o problema.

Uma outra técnica que pode auxiliar na obtenção de informações do especialista é através da Análise de Casos, onde pode-se criar um exemplo e fazer com que o especialista o analise com o acompanhamento do Engenheiro de Conhecimento.

\subsection{Desenvolvimento de um Sistema Baseado em Conhecimento}

$\mathrm{O}$ desenvolvimento de um SBC deve passar por vários estágios. O primeiro deles é identificar o problema. Em seguida, deve-se selecionar um esquema apropriado para representar o conhecimento (regras de produção, frames, etc.) e a programação do conhecimento. É nesse momento que o Engenheiro do Conhecimento transfere o conhecimento humano para a Base de Conhecimento. Um cuidado especial deve ser tomado nesta fase para que a Base de Conhecimento fique bem estruturada. É comum a utilização de uma ferramenta de Engenharia de Conhecimento já existente, que incorpora um Motor de Inferência pré-definido. Assim, a fase de programação do conhecimento é dedicada principalmente à construção da Base de Conhecimento específica do problema. O refinamento da Base de Conhecimento é essencial para que se verifique se todas as informações foram inseridas corretamente e se as regras estão sendo expressas de maneira adequada [ROD93].

Os passos para o desenvolvimento de um SBC da figura 2.5 são mostrados com mais detalhes no esquema da figura 2.7. Cada estágio pode ser repetido várias vezes, até se chegar ao objetivo final, que é encontrar a solução para o problema em tempo igual ou inferior ao de um especialista humano. 


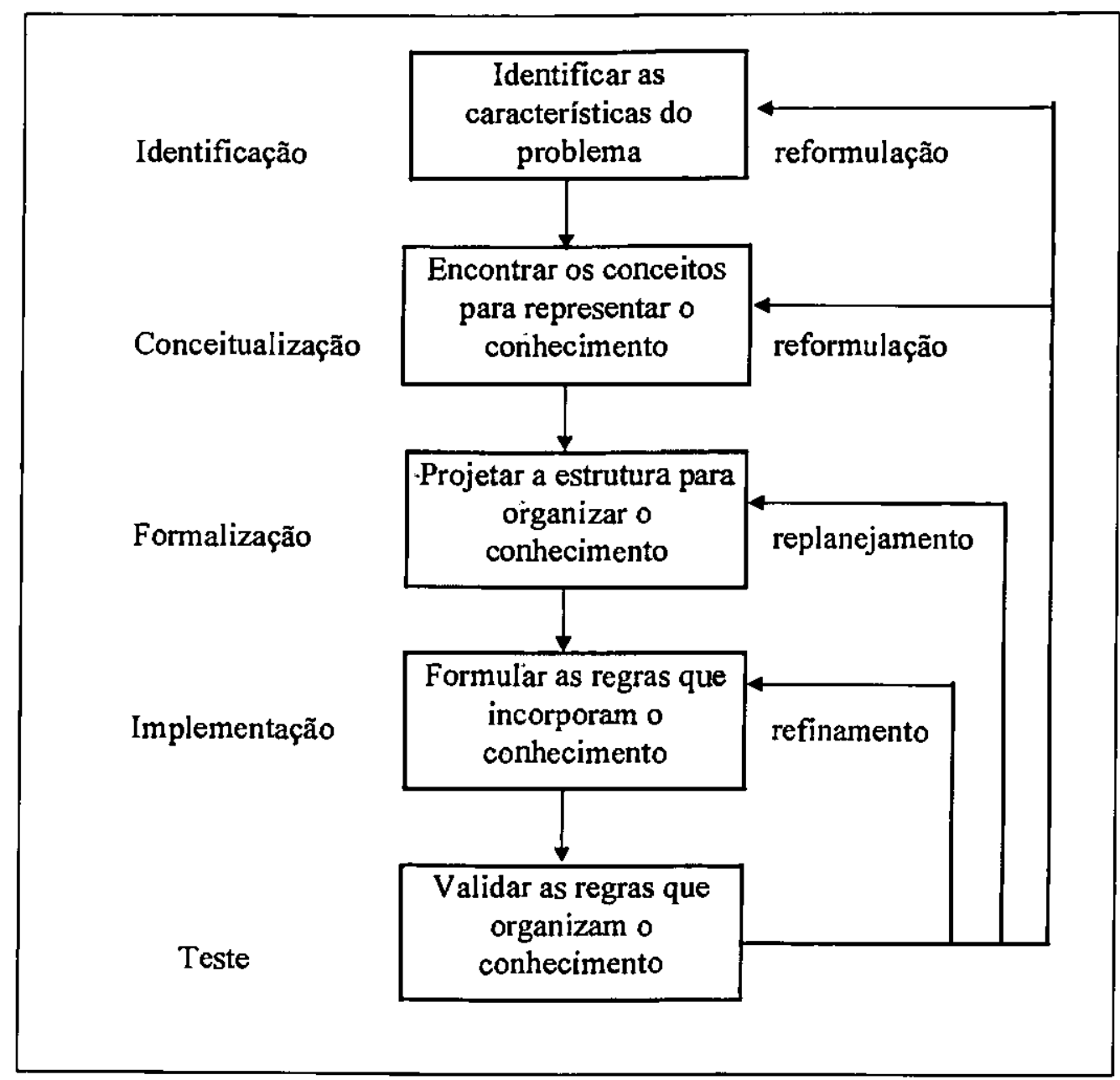

Figura 2.7 - Estágios do Desenvolvimento de um SBC [ROD93].

\subsection{Linguagens, Shells e Ferramentas}

Uma decisão fundamental na definição de um problema é encontrar a melhor forma de modelagem. Em alguns casos a experiência está disponivel para ajudar na escolha do melhor paradigma. Por exemplo, a experiência sugere que um sistema de folha de pagamento será melhor implementado com o uso da programação procedural. A experiência também sugere que é preferivel usar um pacote comercial, se houver um disponível e que atenda às necessidades do usuário, do que desenvolver um. Um guia geral para selecionar um paradigma é considerar o mais tradicional primeiro - programação convencional. A razão para fazer isto é devido à vasta quantidade de experiência que existe com programação convencional e à grande variedade de pacotes comerciais disponíveis. Se um programa não pode ser resolvido pela programação convencional, então deve-se analisar se é possivel mudar para paradigmas não convencionais, como a Inteligência Artificial [GIA94]. 
Como foi explicado na seção 2.2, uma Shell fornece uma seleção de ferramentas de programação para construção de SBCs: a linguagem para representação do conhecimento, um editor, um Motor de Inferência, etc. Já uma ferramenta de desenvolvimento fornece facilidades para construção de sistemas maiores e mais elaborados e incluem técnicas de programação integradas, contendo programação lógica, programação orientada a objetos, uso de regras de produção e também linguagens de programação convencional. O motor de inferência pode ser capaz de usar informação de grandes bases de dados de um outro sistema de computador através de uma rede [RAG92].

Embora Sistemas Baseados em Conhecimento seja um ramo de IA, há ferramentas especiais para seu desenvolvimento que são completamente diferentes do LISP e PROLOG, normalmente utilizadas. Enquanto muitas outras têm sido desenvolvidas, tais como IPL-II, SAIL, CONNIVER, KRL e Smalltalk, a maioria delas estão sendo utilizadas somente em pesquisas [GIA94].

De qualquer forma, o processo de construção de SBCs é facilitado consideravelmente se for usada uma linguagem que ofereça suporte para uma variedade de estruturas, tanto de dados quanto de controle, tais como LISP, Prolog ou uma linguagem que dê suporte a Programação Orientada a Objetos. Entretanto, a maioria dos SBCs são construídos utilizando ferramentas de Engenharia de Conhecimento, o que reduz o tempo de desenvolvimento desses sistemas, como por exemplo, as ferramentas de apoio ART, BABYLON, KEE, ou as Shells INSIGHT, MED2, KES, entre outras [ROD93].

\subsection{Consideraçōes Finais}

Atualmente, são inúmeras as aplicações em Inteligência Artificial: Redes Neurais, Processamento de Linguagem Natural, Robótica, etc. Dentre elas, são os Sistemas Baseados em Conhecimento, principalmente os Sistemas Especialistas, os que despertaram maior interesse comercial, apresentando aplicações em várias áreas.

Uma das primeiras maiores aplicações a aparecer em Sistemas Baseados em Conhecimento foi o DENDRAL, desenvolvido por volta de 1965, para identificação da estrutura química de moléculas. Sistemas especialistas são usados também como ferramentas para exploração de minérios tal como o PROSPECTOR, que descobriu um depósito mineral no valor de cem milhões de dólares [GIA94], e o sistema DIPMETER para óleo, além do MICYN, para diagnóstico de doenças e o XCON, um sistema especialista para configuração de sistemas de computadores, usado pela Digital Equipament Corporation (DEC). 
Por ser uma tecnologia relativamente nova, os Sistemas Especialistas contam com poucas pessoas com experiência no assunto. Sua função é tentar resolver problemas que não podem ser resolvidos através dos sistemas convencionais, ou seja, são bastante apropriados quando o conhecimento do especialista é heurístico e incerto, onde o conhecimento é baseado em experiência, e o especialista pode ter que tentar várias outras alternativas, caso a primeira não funcione.

Devido às suas características, um Sistema Baseado em Conhecimento será desenvolvido neste projeto, a fim de disponibilizar aos criadores de canários de cor todo o conhecimento obtido através de publicações e especialistas da área. O objetivo é aconselhar o canaricultor sobre os melhores casais de canários para acasalamento, entre outras coisas, a fim de se obter as cores desejadas e, por consequêencia, exemplares de maior valor para concursos. 


\section{Canários de Cor}

\subsection{História}

O primeiro canário de que se tem notícia foi encontrado nas Ilhas Canárias, na Costa Africana, Oceano Atlântico, por volta de 1402. Sabe-se que as Ilhas receberam esse nome antes do pássaro. Curiosamente, os romanos chamavam-nas de "Ilhas dos Cães" por serem habitadas por um tipo de raça de cães de grande porte. Como era de se esperar, os romanos tiveram maior interesse em ferozes cães de guarda do que em pequenos pássaros cantantes. A palavra "canário" é uma corruptela de "canis", ou cachorro, em latim [OLS96].

O Canário Selvagem", ou Serinus Canarius, possui pouco mais de doze centímetros, é nevado, de cor verde acinzentada e com partes córneas escuras; o macho apresenta faixas amareladas enquanto que a fêmea possui partes marrom acinzentadas. Sua aparência é bastante similar à do canário verde comum. Já no século XV, tem-se notícias de canários sendo criados como animais de estimação na Europa. Ainda hoje, porém, pode-se encontrar o Canário Selvagem nas Ilhas Canárias, Açores e Cabo Verde [OLS96][SIL87].

Por um período de quinhentos anos, através de criações seletivas, uma grande variedade de canários foi desenvolvida. Alguns foram criados puramente pela sua habilidade vocal, onde a aparência não tinha muita importância. Até a Revolução Industrial, quando ainda não existiam máquinas barulhentas, alguns artesãos costumavam manter canários em suas lojas para entretenimento. Essa prática de manter canários nos locais de trabalho acabou levando-os para as minas de carvão, onde eles serviam de "alerta" ao homem quando morriam devido à ocorrência de gases perigosos [OLS96].

Os ingleses se distraiam fazendo experiências com os tamanhos e formas que um canário poderia apresentar, conseguindo criar algumas variações da raça, entre elas o Norwich, o Yorkshire e o Gloster. Já os franceses e italianos preferiram lidar com a postura dos canários e obtiveram vários exemplares com diferentes curvaturas da espinha. Até o início do século XX, $\mathrm{O}$ canto e a forma dos canários eram alvo da dedicação dos criadores. No entanto, uma mutação apareceu em um criadouro de canários de canto clássico despertando a atenção para a cor dos

Veja fotos do Canário Selvagem no Apêndice B. 
pássaros, iniciando, nesse momento, um novo interesse por parte dos criadores e desencadeando uma série de experimentos, levando às mais de trezentas cores conhecidas atualmente [OLS96].

\subsection{Evolução}

Desde 1478 , os canários são criados em cativeiro no continente europeu, mas, somente em 1709, foi publicado o primeiro livro exclusivamente sobre esses pássaros, cujo autor. Hervieux de Chanteloup, já relacionava vinte e nove variedades distintas pela cor da plumagem, entre eles os canários verdes, canelas, brancos, amarelos e alguns com olhos supostamente vermelhos. Também estavam incluídos os pássaros pintados (mutação do fator enzima) e o fator intenso (mutação do fator nevado) [OBJ96].

A cor verde do canário resulta dos efeitos de vários componentes que entram na formação de suas plumas e penas. Basicamente, o verde é conseguido pela combinação do amarelo do lipocromo com as melaninas negra e marrom e em alguns casos pelo azul refletido por pequenas partículas de melanina negra dispersa na plumagem, mais precisamente nas bárbulas. A presença da melanina marrom, a nuance do amarelo que é extremamente variável e o fator intenso, além de alguns outros fatores, fazem variar o tom do verde, indo do verde musgo ao cinza esverdeado, quase sem brilho, que caracteriza o canário ancestral [SIL87].

A primeira modificação da cor do canário ancestral ocorrida em cativeiro foi o desaparecimento dos pigmentos melânicos em algumas partes da plumagem, numa primeira etapa, e, posteriormente, sua inibição total, transformando o canário verde original em um pássaro totalmente amarelo, com olhos escuros [SIL87]. Esta mutação ocorreu por uma deficiência na função exercida pelo fator enzima, que será tratado posteriormente.

Também o fator nevado presente no canário ancestral sofreu mutações, dando origem ao fator intenso. Esses dois fatores influem na estrutura das plumas e penas, fazendo com que o pássaro intenso apresente normalmente uma plumagem mais compacta, tornando o seu contorno ligeiramente menor. As penas de um pássaro nevado apresentam uma zona despigmentada na extremidade, variável de indivíduo para indivíduo. Já no pássaro intenso, os pigmentos atingem as extremidades das barbas e bárbulas e a coloração da plumagem é uniforme, normalmente se apresentando com um tom mais forte [SIL87].

$\mathrm{O}$ canário ancestral possui cor de fundo amarelo clara. $\mathrm{O}$ amarelo é resultante do depósito de lipocromo nas bárbulas, barbas e eixo das plumas e penas. A ausência do lipocromo deu origem à cor de fundo branca e, consequentemente, aos canários "brancos dominantes", mas com incrustações amarelas em sua plumagem [SIL87]. 
Em 1908, na Nova Zelândia, um casal de pássaros amarelos nevados deram origem a um pássaro totalmente branco. Com acasalamentos consangüíneos, conseguiu-se fixar a mutação. descobrindo-se que o gene se localizava em um autossomo e que era recessivo. Os primeiros pássaros obtidos eram bastante frágeis e de dificil desenvolvimento. A fragilidade de tais pássaros se devia a umá deficiência orgânica, que não os deixava sintetizar a vitamina $\mathrm{A}$. Receberam a denominação de Brancos Recessivos, por já existirem os Brancos Dominantes [OBJ96]. Sabe-se hoje que o branco não chega a ser uma cor e sim uma ausência total do lipocromo amarelo. Deve-se observar, porém, que a terminologia branco recessivo não é considerada correta, apesar de bastante utilizada. A denominação Branco já caracteriza um canário como recessivo [COR95].

Uma outra modificação fez com que o gene responsável pela formação de melaninas negras e marrons perdesse seu potencial. Isso acabou afetando o estágio final do processo de pigmentação, dando origem à mutação canela (ou marrom oxidada). Esta foi a primeira mutação a afetar a cor das melaninas e o canela nada mais é do que um verde onde a melanina negra foi substituída pela marrom [SIL87] [COR95].

Nessa época, já haviam três cores de fundo: o Amarelo, o Branco Dominante e o Branco Recessivo. Adicionados à Linha Escura Clássica (onde os canários apresentam melaninas negra e marrom) e aos fatores Intenso e Nevado, já era possível identificar dezesseis cores bem distintas [OBJ96].

No inicio deste século apareceu a primeira mutação que deu origem à canaricultura visando a cor dos canários. Na Holanda, em um criadouro de canários de canto clássico, do acasalamento de pássaros verdes surgiram canários mutantes, hoje classificados como Ágatas. A característica principal desta mutação é o bloqueio ao depósito de melaninas no início do crescimento das penas e plumas (diluição dos pigmentos negro e canela). A prole consistia somente de fêmeas. Através de acasalamentos consangüíneos, a mutação foi fixada, dando origem a uma nova cor e ao início de uma série de mutações [OBJ96] [SIL87].

$O$ fator que produziu o ágata, conhecido também como primeiro fator de diluição, foi aplicado à mutação canela e os machos verdes obtidos desse acasalamento produziram os primeiros marrons diluídos, denominados isabelinos [OBJ96].

Na década de 20, foi desenvolvido na Alemanha o primeiro trabalho sobre genética de canários de cor. Em 1926, tiveram início alguns estudos para a produção de um canário de cor de fundo vermelha. Como o canário não possuía vermelho em seu patrimônio genético, tentou-se o 
acasalamento com outro pássaro, o Tarim (Spinus Cuculatus), um pássaro de tamanho pequeno, com o corpo colorido de vermelho vivo, cabeça, asas e cauda negras, com barras vermelhas nas asas, conhecido também como Pintassilgo da Venezuela. $O$ canário fêmea utilizado nesta experiência era de cor amarela e, através do acasalamento com um macho Tarim, nasceram híbridos de cor acobreada. Essa experiência passou por várias fases de insucesso, algumas gerando fêmeas estéreis e outras causando a perda da cor obtida anteriormente. Somente após dez anos de tentativas, foram obtidas fềmeas férteis que possuíam os genes responsáveis pela assimilação do vermelho. Com alimentação apropriada, estes canários conseguiram atingir tonalidades de vermelho bem vivas. É importante frisar que, uma vez que o fator vermelho foi inserido no canário artificialmente, através de hibridação, isto não constitui uma mutação [OBJ96].

Dos acasalamentos entre pássaros de fator vermelho surgiram algumas fềmeas esbranquiçadas com zonas de lipocromo idênticas às observadas na fềmea do Tarim. No final dos anos quarenta, surgiram os mosaicos, hoje bastante aperfeiçoados. A princípio, parecia não ser possível obter machos mosaicos, mas com o passar do tempo essa teoria foi abandonada, pois machos com características bem diferentes dos nevados começaram a aparecer. Através de seleção e da introdução de pássaros Gloster (um dos tipos de canários mais populares) pelos italianos nos plantéis de mosaicos, obteve-se um novo tipo de mosaico, onde o macho e a fềmea apresentam dimorfismo típico [OBJ96].

Já na década de cinqüenta, três novas mutações apareceram: o marfim, o pastel e o opalino [OBJ96].

A mutação marfim surgiu de um casal de amarelos de canto clássico, no começo da década. A mutação ocorreu em uma fềmea, que possuía um amarelo muito suave, contrastante com a cor dos pais e irmãos, apresentando uma uniformidade de coloração perfeita. A utilização de acasalamentos consangüíneos permitiu fixar a mutação e classificá-la como recessiva e sexoligada [OBJ96].

Em 1957, na Itália, foram apresentados os primeiros pastéis melânicos. Esta mutação se originou de um isabelino normal. O fator pastel é também conhecido como segundo fator de diluição, pois sua ação é mais intensa sobre as feomelaninas e faz praticamente desaparecer o desenho dos "marrons", deixando, porém, leves traços nos canários canelas. A mutação foi transferida para os negro-marrons e nestes notou-se também a ação do fator sobre as melaninas negras [OBJ96].

\footnotetext{
Veja fotos do pássaro Tarim no Apêndice B.
} 
No ano seguinte, em Nuremberg, Alemanha, um dos filhotes de um casal de canários verdes de canto clássico se diferenciava bastante dos demais. Ao invés de apresentar as melaninas fortemente oxidadas, seus pigmentos melânicos estavam diluídos de tal modo que o negro ficara com uma tonalidade cinza azulada e o marrom praticamente desaparecia da plumagem. Os pés e bico, porém, continuavam escuros, aparentemente sem sofrer a ação do novo fator de diluição. Por analogia da plumagem com a pedra preciosa, esses canários foram denominados opalas e, posteriormente, opalinos. Esta mutação é recessiva em relação ao seu alelo original e se localiza em um autossomo [OBJ96].

Por volta de 1964, em Bruxelas, Bélgica, surgiu uma nova mutação cujo fenótipo podia ser facilmente confundido com um lipocrômico vermelho ou um pastel isabelino, mas que possuía uma subplumagem bege pálido e olhos vermelhos brilhantes, cuja cor não se alterou com o desenvolvimento do pássaro. Esse fator recebeu a denominação "Ino", localiza-se em um autossomo, é recessivo e inibe totalmente as melaninas negras, permitindo apenas o depósito das melaninas marrons periféricas [OBJ96].

$O$ fator Ino provoca o desaparecimento das eumelaninas negras e marrons da plumagem, mas não da subplumagem (não aparente no canário). A única melanina exibida na plumagem externa e de contorno destes canários é a feomelanina, que deve se apresentar o mais forte possível (marrom chocolate). Nos canários melânicos, a melhor manifestação do fator Ino é observada nos pássaros oxidados (em particular os canelas) onde o fator é denominado "Feo-ino" [HUR96].

Também na década de 60 surgiu uma nova mutação, o fator acetinado ou "ino sexoligado". Apareceu na Argentina, em 1967 e na França, em 1969. Os pássaros possuíam olhos vermelhos. Contudo, a distribuição das melaninas diferenciava-os dos inos autossomais. Ao contrário dos feo-ino, as melaninas periféricas eram inibidas e somente a melanina marrom aparecia no lugar correspondente às estrias, bastante diluída. Havia porém pássaros que se assemelhavam aos lipocrômicos [OBJ96].

Os pássaros de origem marrom que apresentam marcação nítida nas estrias são denominados "acetinados típicos", enquanto que os de origem negro marrom se apresentam praticamente como lipocrômicos e são denominados "acetinados diluídos". Sendo um fator sexo-ligado e devido à maior facilidade de manuseio, hoje quase todos os lipocrômicos de olhos vermelhos são de origem acetinada [OBJ96].

Uma modificação estrutural das células exteriores das penas resultou em uma mutação denominada "Fator Ótico para o Azul". A luminosidade produzida pelo espectro solar, 
decomposta em radiações, origina várias nuances de cor, que podem ser observadas num mesmo canário em diferentes períodos do dia, ou seja, cores mais amenas de manhã e mais fortes ao entardecer. A plenitude da pureza da cor se observa ao meio-dia. Esse fator transmite o efeito ótico que dá à cor amarela um tom esverdeado, daí a denominação Amarelo Limão [COR95].

Os canários Asas-cinza tiveram origem na Itália, em 1966. Esta mutação é, na verdade, uma variante do fator pastel e se manifesta principalmente nos negro-marrons oxidados. Estes pássaros possuem uma pigmentação bastante diluída na parte média das grandes penas da asa e da cauda, contrastando com as extremidades onde a melanina negra persiste. A tonalidade acinzentada, típica do negro marrom pastel, deve atuar em toda a plumagem [OBJ96].

A mutação topázio aconteceu na França, na década de 80, sendo oficializada em 1993 na Europa e em 1994 no Hemisfério Sul. A alteração surgiu do fator ino e os pássaros que apresentaram-na possuíam melaninas sempre marrons no local das estrias, olhos vermelho escuros e bandas despigmentadas dos dois lados das penas, o que acabou dando origem ao seu nome. Os canários topázio são perfeitamente definidos nos negro marrons, tanto oxidados como diluídos (ágatas), onde a mutação melhor se expressa [OBJ96].

Também na década de 80 nasceu um canário, filho de um casal de ágatas, que se assemelhava bastante a um ágata opalino, mas que possuía olhos vermelhos. A mutação foi fixada e cruzamentos com inos, acetinados e topázios sempre produziam filhotes dos tipos clássicos. O fator é recessivo autossomal e foi denominado "Eumo" [OBJ96].

A última mutação de que se tem notícia ocorreu em 1986, na Espanha. O fator "Ônix" se originou do acasalamento entre o canário clássico homozigoto verde intenso e o canário azul. Como o fator eumo, o fator ônix também foi classificado como recessivo autossomal [OBJ96].

A ordem, data e local onde as mutações apareceram pela primeira vez não são precisas $\mathrm{e}$ podem não ser totalmente verdadeiras. Isso porque há inúmeros criadores espalhados por todo o mundo e somente aqueles que observam seus canários e têm conhecimento suficiente para reconhecer uma mutação quando ela aparece é que têm condições de fixá-la através de acasalamentos corretos. Também não é raro detectar uma modificação na cor de um pássaro e não conseguir reproduzi-la, fazendo com que aparentemente ela seja perdida. O que se tentou fazer aqui foi relacionar todas as mutações conhecidas atualmente, ou pelo menos as principais, colocando-as numa ordem razoável e dando algumas poucas características de cada uma. 


\subsection{A Genética dos Canários}

A genética dos canários é um campo bastante desenvolvido. Todas as cores dos canários se baseiam em genes que controlam a melanina e o lipocromo. A melanina é preta no canário ancestral e o lipocromo (cor de fundo ou de base) é de cor amarela. A combinação de preto e do amarelo dá a aparência de um pássaro verde. Alterações nas cores e nos componentes da plumagem do canário ancestral trouxeram as diversas mutações hoje existentes. Essas variações podem atuar tanto na cor de fundo como nos pigmentos melânicos, reduzindo sua expressão em graus variáveis, inibindo seu aparecimento e às vezes aumentando seu efeito. $O$ gene que remove a melanina é parcialmente dominante. Um único fator desse gene provoca um tom variado, com cores claras e escuras, enquanto que dois fatores determinam um canário claro, que exibe somente a cor de fundo (ou lipocromo) que pode se apresentar em várias gradações de vermelho, amarelo ou, simplesmente, branco [OLS96][OBJ96].

A melanina no eixo das penas (eumelaninas) pode ir do negro ao cinza azulado, do marrom escuro ao bege claro, ou mesmo estar ausente. Já as melaninas periféricas (feomelaninas) variam do marrom escuro ao bege claro, podendo também não se exteriorizarem. Além dessas variaçóes de intensidade de coloração, a estrutura das barbas e bárbulas pode mudar, criando variações que também concorrem para a mudança de cor [OBJ96].

\subsubsection{Noçōes Básicas e Convençōes Utilizadas}

Sabe-se que um ser é composto por um conjunto de células e que cada célula possui o mesmo número de cromossomos e ainda que este número é sempre par nas espécies puras. Acredita-se, atualmente, que as células dos canários possuam 40 pares de cromossomos ${ }^{3}$. Esses pares são constituídos de cromossomos idênticos denominados homólogos, com exceção do par de cromossomos sexuais, onde o macho possui dois cromossomos idênticos (XX), enquanto a fêmea possui um cromossomo $\mathrm{X}$ e um $\mathrm{Y}$. Supõe-se que o cromossomo $\mathrm{Y}$ seja apenas determinante do sexo, não possuindo genes [OBJ96][SIL87].

O gameta, ou célula germinativa, possui apenas um dos cromossomos de cada par das células comuns. A união dos gametas do macho e da fềmea forma o zigoto, célula inicial que dará origem ao novo indivíduo. Para que cada gameta passe a ter metade do número de cromossomos das células, ele passa por um processo de redução, denominado meiose (exempli-

\footnotetext{
Em [MAT92] o autor afirma que os canários apresentam apenas 21 pares de cromossomos. Tal diferença pode ser devido aos tipos de cromossomos que o canário possui, a maioria microcromossomos. Segundo [OLS96] um microcromossomo é muito pequeno para ser identificado positivamente como um cromossomo. Provavelmente dentre os 21 pares citados em [MAT92] somente os macrocromossomos foram considerados.
} 
ficado na figura 3.1) composto das seguintes fases [SIL87]:

A - Os cromossomos estão separados nas células, desenvolvendo sua tarefa de controlar a fabricação das proteínas.

B - Quando uma célula dos testículos ou do ovário está próxima da meiose, os cromossomos se arrumam de modo que cada cromossomo recebido do pai se emparelhe com o seu homólogo, recebido da mãe.

C - Cada um dos pares de cromossomos se duplica, produzindo uma cópia exata de si mesmo. Assim, cada grupo passa a conter quatro cromossomos. Neste momento, podem haver trocas de partes de segmentos do cromossomo materno com partes correspondentes do cromossomo paterno (crossing-over ou recombinação).

D - Ocorre uma segregação aleatória, possibilitando a ocorrência de diversas combinações. A célula é dividida em quatro partes, cada uma contendo um conjunto de $\underline{n}$ cromossomos, com todas as instruções necessárias para a formação de um novo ser.

E - A célula se separa formando os quatro gametas, espermatozóides no macho e óvulos na fêmea. No caso da fêmea, somente um desses gametas se tornará o óvulo, enquanto que os outros três morrerão.

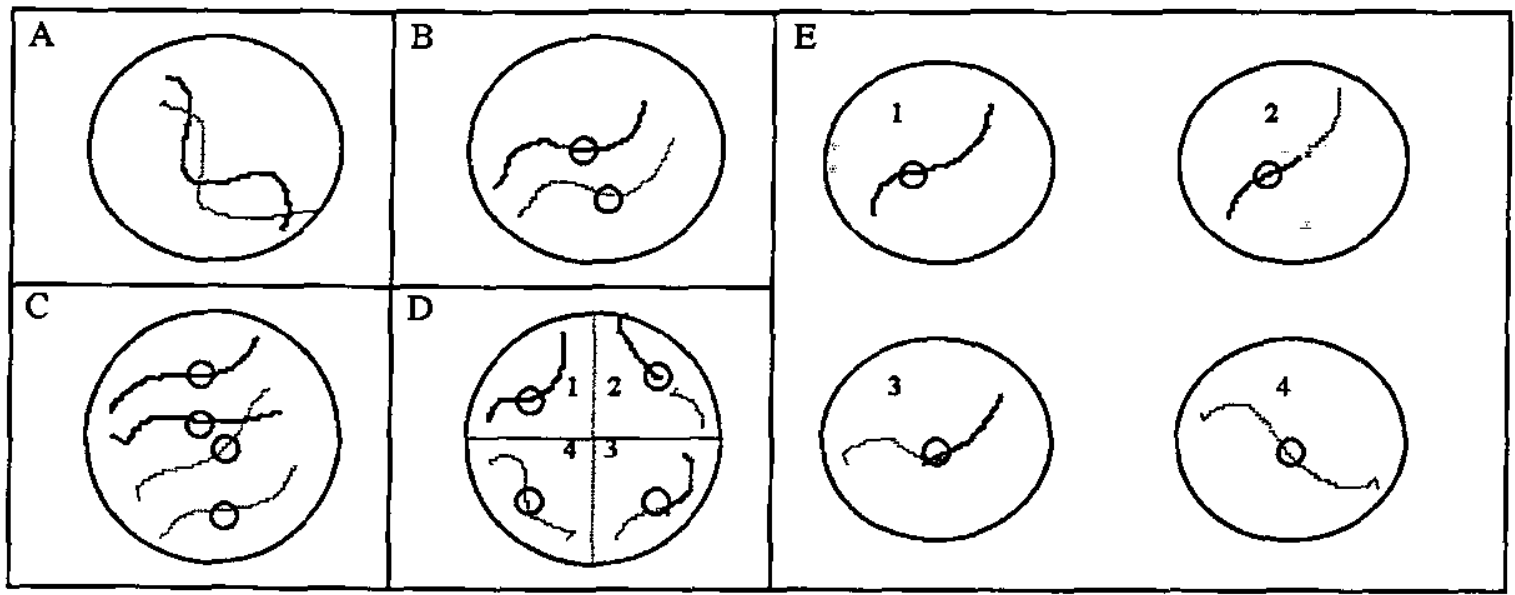

Figura 3.1 - Exemplo simplificado do processo de meiose [SL87].

Ao final desse processo, cada gameta será uma célula haplóide, contendo apenas um conjunto de cromossomos (n). Somente após a fertilização haverá um conjunto completo de cromossomos (2n), transformando o gameta em uma célula diplóide [SIL87].

Os gametas gerados através do processo de recombinação ou crossing-over são chamados "recombinantes" (E-2 e E-3 da figura 3.1). No entanto, há uma tendência de todos os genes de um mesmo cromossomo se transmitirem juntos. Tal fenômeno é conhecido como ligação 
fatorial, ou linkage, e os gametas gerados, idênticos aos iniciais, são denominados "parentais" (figura 3.1, E-1 e E-4). O processo da recombinação é resumido na figura 3.2 [OBJ96][SIL87].

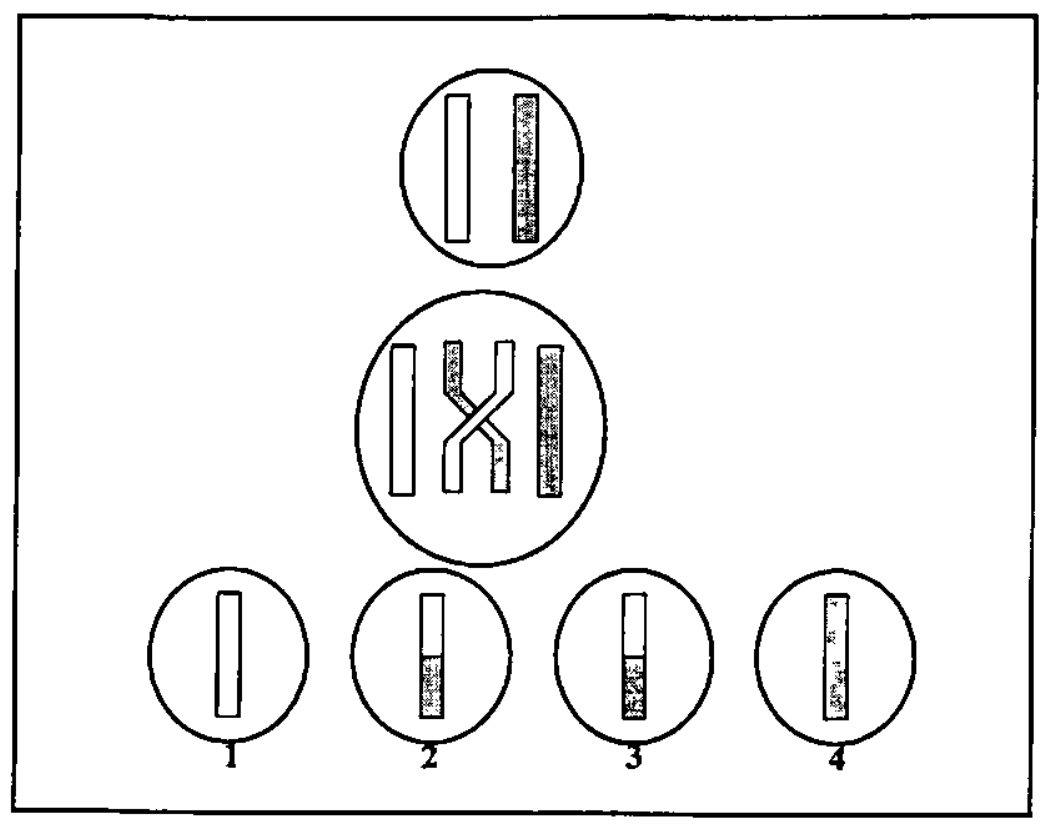

Figura 3.2 - Recombinação ou Crossing-over [OBJ96]

Gametas possiveis de serem gerados: 1,2,3,4.Gametas parentais: 1 e 4.

$\mathrm{O}$ outro processo que ocorre durante a meiose na criação dos gametas, a segregação independente, é exemplificado na figura 3.3. Cada um dos cromossomos se separa do seu par, se duplica e se move independentemente para diferentes partes da célula em divisão [OLS96].

Os processos que ocorrem durante a meiose garantem uma grande variação nas instruções contidas dentro dos gametas e isto é refletido nas diferenças aparentes entre a progênie de um simples casal [SIL87].

Na formação do zigoto, entram um conjunto de cromossomos do pai e outro da mãe. Assim, para cada locus de cada cromossomo, o zigoto pode ter [SIL87]:

1. Dois alelos primitivos ou não mutantes, onde o fenótipo apresenta uma característica normal, pois os dois alelos contêm instrução para isso (homozigose).

2. Um alelo mutante e o outro não mutante, caracterizando uma heterozigose, pois os alelos do locus possuem instruções distintas para uma mesma característica.

3. Dois alelos mutantes. Neste caso, o fenótipo apresenta a característica mutante, pois as duas instruções são idênticas (homozigose).

A instrução que determinará o fenótipo depende da relação entre o alelo primitivo e o alelo mutante. No caso da heterozigose, se um dos genes consegue expressar no fenótipo suas 
características, ele é considerado dominante em relação a seu alelo. A dominância pode ser total ou não. No caso da dominância parcial (também conhecida como intermediária, semidominância ou co-dominância), o fenótipo apresentará características intermediárias [SIL87].

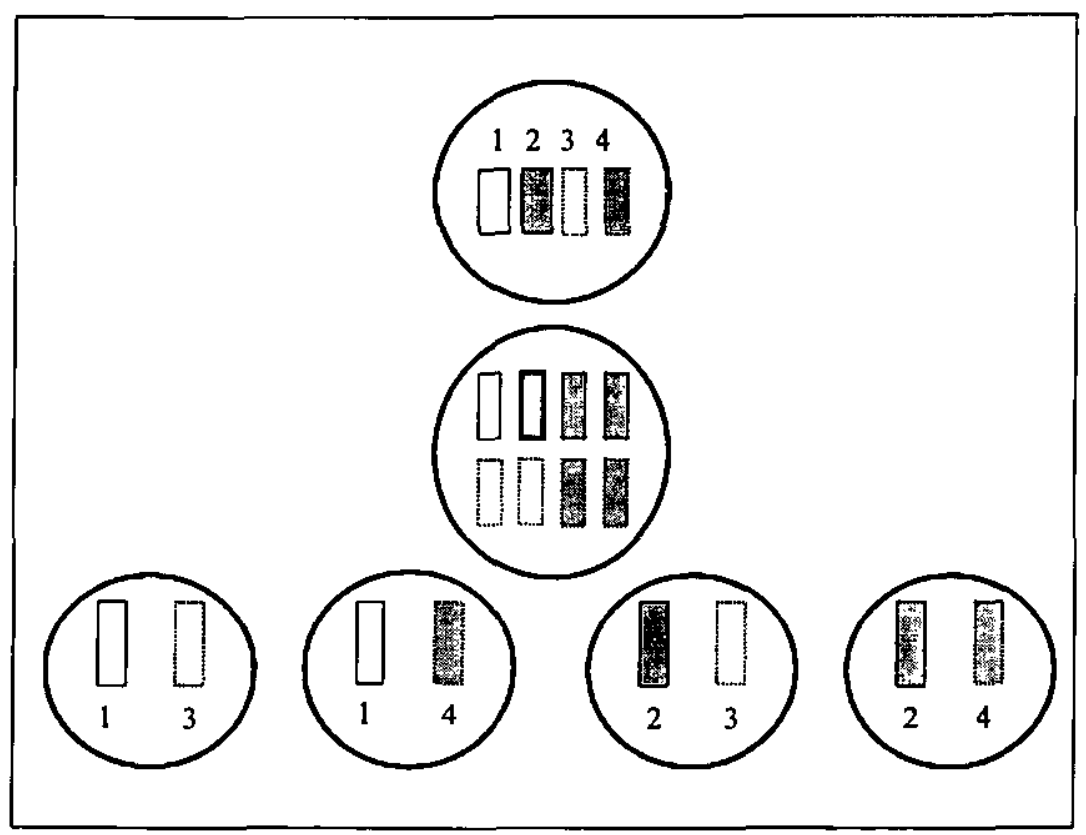

Figura 3.3 - Segregação Independente, com dois pares de cromossomos [SIL87].

No caso da dominância, para os três genótipos possiveis (AA, Aa e aa) haverá somente dois fenótipos, pois o heterozigoto (Aa) terá fenótipo idêntico ao duplo dominante (AA). Já na semi-dominância, para os três genótipos descritos acima, haverá três fenótipos, pois o fenótipo heterozigoto $(\mathrm{Aa})$ terá características intermediárias entre as que seriam determinadas por cada gene, se agisse isoladamente [SIL87].

O gene cujo efeito não se faz sentir no fenótipo quando em heterozigose é denominado recessivo.

A convenção para representar em fórmulas os genes e cromossomos é utilizar a letra maiúscula para designar os genes dominantes e a letra minúscula para genes recessivos. Um traço de fração é utilizado para separar os alelos de um cromossomo. Assim, $\frac{X N O}{X N O}$ identifica de forma simplificada um pássaro macho verde homozigoto, enquanto que $\frac{X N O}{Y}$ identifica uma fềmea verde.

Os genes originais e seus mutantes serão representados na figura 3.4: 


\begin{tabular}{|c|c|c|c|c|}
\hline$x$ & $N$ & $\begin{array}{l}\text { Presença de negro e mar- } \\
\text { rom. }\end{array}$ & n & Presença só de marrom \\
\hline gados & $\mathrm{O}$ & $\begin{array}{l}\text { Oxidação total das mela- } \\
\text { ninas }\end{array}$ & $\begin{array}{l}\text { oa } \\
\text { os }\end{array}$ & $\begin{array}{l}\text { Oxidação parcial das me- } \\
\text { laninas } \\
\text { Acetinado }\end{array}$ \\
\hline$x$ & $\mathrm{Ma}$ & Normal, não marfim & $\mathrm{ma}$ & Marfim \\
\hline & $\bar{P}$ & Normal, não pastel & $\begin{array}{l}\mathrm{p} \\
p\end{array}$ & $\begin{array}{l}\text { Pastel } \\
\text { Asas Cinza }\end{array}$ \\
\hline & $E$ & Melanização completa & $\mathrm{e}$ & Ausência de melaninas \\
\hline & I & Fator intenso & i & Fator nevado \\
\hline & $\mathrm{A}$ & Amarelo forte & $\mathrm{a}$ & Amarelo fraco \\
\hline & $\mathrm{Bd}$ & Branco dominante & $\mathrm{bd}$ & Lipocromo normal \\
\hline & $\mathrm{Br}$ & Lipocromo normal & $\mathrm{br}$ & Branco recessivo \\
\hline$m$ & $V^{*}$ & Presença do vermelho & $\mathrm{v}$ & Ausência do vermelho \\
\hline & $\mathrm{M}$ & Não mosaico & $\mathrm{m}$ & Mosaico \\
\hline & Op & Normal, não opalino & op & Opalino \\
\hline & $\begin{array}{l}\overline{\mathrm{IN}} \\
\mathrm{O}\end{array}$ & Normal, não ino & $\begin{array}{l}\text { ino } \\
\mathrm{tz}\end{array}$ & $\begin{array}{l}\text { Ino } \\
\text { Topázio } \\
\end{array}$ \\
\hline $8 x+3 x$ & $\bar{B}$ & $\begin{array}{ll}\begin{array}{l}\text { Ausência da estrutura } \\
\text { para o azul }\end{array} & \\
\end{array}$ & $\mathrm{b}$ & $\begin{array}{l}\text { Presença da estrutura para } \\
\text { o azul }\end{array}$ \\
\hline & & Eumo $^{\text {sth }}$ & & \\
\hline & & Ónix & & \\
\hline
\end{tabular}

Figura 3.4 - Relação dos genes autossomais e sexo-ligados e seus mutantes [OBJ96].

Em todos os cruzamentos os machos serão identificados primeiro, seguidos das fêmeas.

\subsubsection{Os Fatores Enzima, Intenso e Nevado}

As cores dos canários são classificadas dentro de duas linhas: linha clara e linha escura. Os canários da linha escura (ou melânicos) existem porque há um gene localizado em um autossomo que possibilita o depósito das melaninas. Este gene, representado por E, é denominado "fator enzima" e faz parte do patrimônio do canário selvagem. Quando ocorre em dose dupla, ou seja, quando aparece ocupando o locus dos autossomos homólogos, permite que o negro-marrom $(N)$ e a oxidação total das melaninas $(O)$ desempenhem suas funções em toda sua plenitude. Os canários homozigotos recessivos, isto é, aqueles que apresentam os genes mutantes para este fator são classificados dentro da linha clara [SIL87].

\footnotetext{
* Apesar de ter sido inserido no canário através de hibridismo, o fator vermelho será considerado como um gene normal.

* A mutação Eumo, apesar de já fixada e classificada como recessiva e autossomal, ainda não está sendo considerada no Hemisfério Sul a nível de concursos e, portanto, não está sendo muito divulgada nas publicações.

\# O fator ônix já foi classificado como sendo recessivo e autossomal, mas ainda não foi reconhecido oficialmente e, como o fator Eumo, também não tem sido muito divulgado.
} 
Como já mencionado anteriormente, a mutação no fator enzima fez com que desaparecesse a pigmentação em algumas partes da plumagem do canário até sua inibição total. A cor dos olhos do pássaro não é afetada, continuando escura, mas o canário verde se transforma em um pássaro totalmente amarelo [SIL87].

A dominância de $\underline{E}$ em relação ao seu recessivo não é total. Assim, o genótipo $\underline{E} \underline{E}$ origina um fenótipo melânico, enquanto ee leva a um fenótipo isento de melaninas (lipocrômico) e o

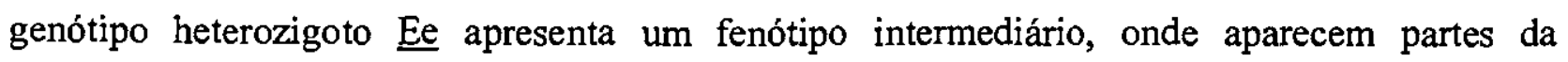
plumagem com melaninas e outras onde elas não se manifestam, dando origem aos pintados.

Assim, uma representação um pouco mais completa do canário verde seria $\frac{X N O}{X N O} \frac{E}{E}$ para um macho e $\frac{X N O}{Y} \frac{E}{E} \quad$ para uma fêmea [SIL87].

Os traços de fração distintos mostram que os genes envolvidos estão em cromossomos diversos, isto é, $\mathrm{N}$ e $\mathrm{O}$ estão no cromossomo sexual e $\mathrm{E}$ em um autossomo. Nas fórmulas de canários da linha escura não é necessário representar o fator enzima, uma vez que ele é parte integrante de todos os patrimônios genéticos dos melânicos e não influencia nos resultados [SIL87].

O canário ancestral é nevado, sendo o intenso uma mutação do fator primitivo. Os fatores intenso e nevado influem na estrutura das plumas e das penas. Nas plumas de um pássaro nevado, as barbas e bárbulas são mais longas e, se comparadas com as plumas de um pássaro intenso, as do pássaro nevado serão maiores. Uma outra característica da presença do fator nevado é a despigmentação na extremidade das penas, dando a impressão da plumagem ter sido tingida por uma névoa branca. As penas do pássaro intenso são menores e mais rígidas e os pigmentos atingem as extremidades das barbas e bárbulas dando um tom mais forte e uniforme à coloração da plumagem [SIL87].

Apesar de alguns pássaros intensos apresentarem certo grau de nevadismo, este fator é considerado dominante total em relação ao seu alelo primitivo, o nevado. Os fatores intenso (I) e nevado (i) são independentes do sexo dos genitores, isto é, situam-se em um locus de um autossomo. Sendo o intenso dominante total, os genótipos intenso a 1 fator (IF), (Ii), e intenso a dois fatores (2F), (II), apresentam o mesmo fenótipo. Os acasalamentos possíveis são [SIL87]:

\begin{tabular}{|c|c|c|c|}
\hline \multicolumn{4}{|c|}{ 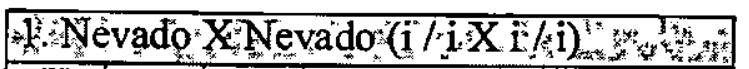 } \\
\hline $\mathrm{X}$ & $\mathrm{i}$ & $\bar{i}$ & Probabilidade \\
\hline 1 & $\overline{\mathrm{i} / \mathrm{i}}$ & $\mathrm{i} / \mathrm{i}$ & \multirow{2}{*}{$\begin{array}{c}100 \% \\
\text { nevados }\end{array}$} \\
\hline$\overline{\mathrm{i}}$ & $\mathrm{i} / \mathrm{i}$ & $\mathrm{i} / \mathrm{i}$ & \\
\hline
\end{tabular}

\begin{tabular}{|c|c|c|l|}
\hline \multicolumn{4}{|c|}{ 2. Nevado Xintenso (lE) $(\mathrm{i} / \mathrm{i}$ X I / $/ \mathrm{i})$} \\
\hline $\mathrm{X}$ & $\mathrm{i}$ & $\mathrm{i}$ & \multicolumn{1}{|c|}{ Probabilidade } \\
\hline $\mathrm{I}$ & $\mathrm{I} / \mathrm{i}$ & $\mathrm{I} / \mathrm{i}$ & $50 \%$ intensos (IF) \\
\hline $\mathrm{i}$ & $\mathrm{i} / \mathrm{i}$ & $\mathrm{i} / \mathrm{i}$ & $50 \%$ nevados \\
\hline
\end{tabular}



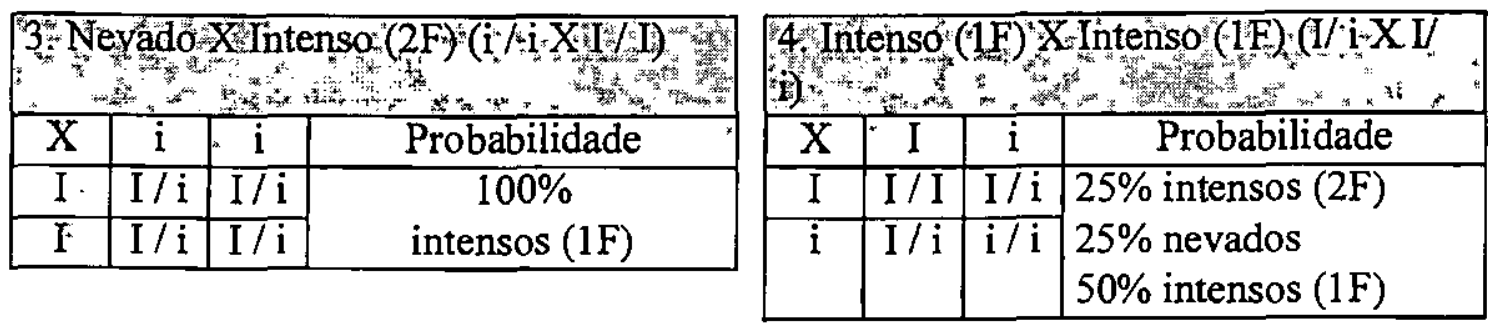

\begin{tabular}{|c|c|c|c|}
\hline \multicolumn{4}{|c|}{ 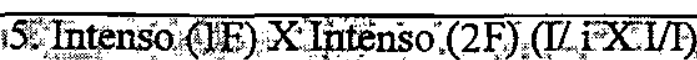 } \\
\hline $\mathrm{X}$ & I. & I & Probabilidade \\
\hline $\bar{I}$ & $\mathrm{I} / \mathrm{I}$ & $\mathrm{I} / \mathrm{I}$ & $50 \%$ intensos $(1 \mathrm{~F})$ \\
\hline$\overline{\mathrm{i}}$ & $\mathrm{I} / \mathrm{i}$ & $\mathrm{I} / \mathrm{i}$ & $50 \%$ intensos $(2 \mathrm{~F})$ \\
\hline
\end{tabular}

\begin{tabular}{|c|c|c|c|}
\hline \multicolumn{4}{|c|}{ 6.Intenso: $(2 \mathrm{~F}) \mathrm{X}$ Intenso:(2F) (I/LX $\mathrm{I} / \mathrm{I})$} \\
\hline $\mathrm{X}$ & $\mathrm{I}$ & $\mathrm{I}$ & Probabilidade \\
\hline $\mathrm{I}$ & $\mathrm{I} / \mathrm{I}$ & $\mathrm{I} / \mathrm{I}$ & $100 \%$ \\
\hline $\mathrm{I}$ & $\mathrm{I} / \mathrm{I}$ & $\mathrm{I} / \mathrm{I}$ & intensos $(2 \mathrm{~F})$ \\
\hline
\end{tabular}

Uma vez que o fenótipo apresentado pelo fator intenso (1F) é idêntico ao apresentado pelo intenso $(2 \mathrm{~F})$, a única forma para se distinguir um do outro seria através do acasalamento com um nevado. Se aparecer pelo menos um nevado, pode-se assegurar que o reprodutor é um intenso (1F), mas devido à aleatoriedade da formação dos gametas, é possível que surjam várias ninhadas de pássaros intensos e nenhum nevado. Portanto, a ausência de pássaros nevados na prole não garante o fator duplo no reprodutor. Nestes casos, a probabilidade é utilizada para determinar se o pássaro possui o fator intenso (2F) ou não, seguindo as seguintes regras [SIL87]:

1. A probabilidade de nascer um pássaro intenso de um acasalamento (1F) $\mathrm{X}$ nevado é de $50 \%$ ou $1 / 2$;

2. A probabilidade de que o primeiro pássaro nasça intenso é também de $50 \%$ ou $1 / 2$;

3. A probabilidade de que os dois primeiros pássaros sejam intensos é de $1 / 2 \times 1 / 2=1 / 2^{2}=$ $1 / 4$;

4. A probabilidade de que os três primeiros sejam intensos é de $1 / 2 \times 1 / 2 \times 1 / 2=1 / 2^{3}=1 / 8 \mathrm{e}$ a probabilidade de que os $n$ primeiros pássaros sejam todos intensos é igual a $1 / 2^{n}$.

Assim, se de um acasalamento intenso $\mathrm{X}$ nevado surgirem os primeiros sete pássaros intensos, a probabilidade do sétimo ser também intenso é de $1 / 2^{7}=1 / 128$, ou seja, menor que $1 \%$. Se o pássaro nascido após os seis primeiros intensos for também intenso, pode-se considerar com erro inferior a $1 \%$ que todos os pássaros que nascerem deste acasalamento serão intensos e que o reprodutor é um intenso $(2 \mathrm{~F})$. No entanto, esta conclusão se torna válida se forem verificados os sete primeiros ovos fecundados e eclodidos. Os ovos não fecundados não acarretam problemas, mas os fecundados e não eclodidos podem vir a comprometer esta experiência [SIL87]. 
Como o fator intenso modifica a estrutura das penas, tornando-as mais compactas e mais rígidas, os acasalamentos constantes entre intensos geram pássaros com penas duras e quebradiças além de apresentarem algumas zonas do corpo isentas de plumas. Devido a esse problema, acredita-se que o fator intenso seja letal quando em dupla dose, ou seja, os pássaros tendem a morrer antes de chegarem à maturidade [SIL87][WAL87].

\subsubsection{A Cor de Fundo Amarela}

O depósito de carotenóides nas partes das plumas e das penas determinam a cor amarela. Os carotenóides são absorvidos através dos alimentos e transformados pelo figado em pigmentos lipossolúveis que colorem a pele, as plumas e as penas durante o crescimento das mesmas. Este pigmento é denominado lipocromo e depende de três ações distintas independentes, controladas por genes específicos [SIL87]:

1. A formação da matéria prima, processada no figado;

2. O lançamento da matéria prima transformada em lipocromo no fluxo sangúíneo com a coloração da pele, resultante do depósito do lipocromo na mesma, denominada oxidação dos carotenóides;

3. A coloração das penas e plumas resultante da ação de catalisadores sobre o lipocromo que chega às barbas e bárbulas.

O canário só terá sua plumagem colorida totalmente de amarelo se as três ações ocorrerem [SIL87].

$\mathrm{O}$ canário ancestral possuía cor de fundo amarelo-claro, mas, atualmente, já existem diversas tonalidades que podem afetar o aspecto do lipocromo quando combinadas com a ação de outros genes. $O$ tom do amarelo depende basicamente do potencial genético do pássaro, mas pode ser modificado pelos fatores intenso e nevado [SIL87].

De uma maneira simplificada, a cor básica do amarelo pode ser considerada dependente de um par de alelos autossomais representados por " $A$ " para o amarelo forte e "a" para o amarelo pálido ou fraco. Como há co-dominância entre os alelos, para os três genótipos possíveis há também três fenótipos. Assim, as combinações possíveis seriam: $\underline{\mathrm{AA}}$, determinando a cor amarelo escuro, Aa para amarelo médio e aa para amarelo claro, tendendo ao branco [SIL87]. 


\subsubsection{A Cor de Fundo Branca}

A cor de fundo branca é determinada pela ausência de lipocromo nas plumas e penas. A ausência parcial ou total do lipocromo pode ser determinada pela falta de uma, duas ou das três ações responsáveis pela deposição do lipocromo descritas na seção anterior (3.3.3).

Os canários de cor de fundo branca surgiram na Alemanha por volta de 1700 e hoje são conhecidos como "brancos dominantes". Estes pássaros têm como característica algumas incrustações amarelas em sua plumagem, mas um critério de seleção foi empregado visando obter brancos com um mínimo de incrustações lipocrômicas. Após esta seleção, obteve-se um pássaro de cor de fundo branca onde apenas as rêmiges (penas mais longas das asas) apresentam traços lipocrômicos [MAT92][SIL87].

O canário selvagem possuía um gene autossomal bd responsável pela deposição do lipocromo na plumagem. Face às condições citadas anteriormente, surgiu em cativeiro o mutante $\underline{\mathrm{BD}}$, dominante, que perdeu sua capacidade de produzir quase totalmente os elementos necessários para a fixação do lipocromo na plumagem. A variação das incrustações lipocrômicas nos pássaros branco dominantes sofre influência de vários outros fatores, como o fator intenso, que aumenta a zona de coloração nas rêmiges e, em alguns casos, faz com que apareçam zonas lipocrômicas nas retrizes (penas da cauda) e até mesmo na nuca [SIL87].

As representações utilizadas para esses pássaros são:

\begin{tabular}{|l|l|}
\hline Branco dominante & $\frac{\mathrm{BD}}{\mathrm{BD}}$ ou $\frac{\mathrm{BD}}{\mathrm{bd}}$ \\
\hline Lipocrômico & $\frac{\mathrm{bd}}{\mathrm{bd}}$ \\
\hline
\end{tabular}

O pássaro totalmente branco que surgiu em 1908 na Nova Zelândia não possuía qualquer infiltração lipocrômica e apresentava pele de cor violácea. Este pássaro foi gerado por um casal de pássaros amarelos nevados. $O$ retro-cruzamento (filho com um dos progenitores) foi utilizado e outros pássaros brancos nasceram, apresentando, porém, uma deficiência ao nível da transformação de carotenóides em lipocromo. $\mathrm{O}$ tom da pele deve-se à gordura incolor que se situa sob a pele, causando um efeito ótico da coloração dos vasos sangüíneos que a irrigam [SIL87].

De acordo com a sistemática adotada, $\underline{B R}$ representará o gene original existente no canário selvagem, enquanto que a mutação responsável pelo surgimento do canário totalmente branco será representada por $\underline{b r}$ (branco recessivo). Este par alelomórfico em dupla dose impede 
qualquer manifestação lipocrômica, qualquer que seja seu potencial genético. Assim, a definição de um pássaro lipocrômico envolve três loci e é representado da seguinte forma [SIL87]:

\begin{tabular}{|l|l|}
\hline Amarelo escuro & $\frac{\mathrm{A}}{\mathrm{A}} \frac{\mathrm{bd}}{\mathrm{bd}} \frac{\mathrm{BR}}{\mathrm{BR}}$ ou br \\
\hline Amarelo médio & $\underline{\mathrm{A}} \frac{\mathrm{bd}}{\mathrm{BR}}$ \\
\hline Amarelo claro & $\underline{\mathrm{a}} \frac{\mathrm{bd}}{\mathrm{b}} \frac{\mathrm{BR}}{\mathrm{Bd}}$ ou br \\
\hline
\end{tabular}

Como os três loci envolvidos se situam em autossomos distintos, ocorre o fenômeno denominado epistasia do gene branco recessivo em relação a todos os outros genes que influenciam o fenótipo lipocrômico. Epistasia é a capacidade que um gene apresenta de mascarar no fenótipo as características de um outro gene situado em outro cromossomo. Por isso, quando o gene para o branco recessivo aparece em dupla dose (br/br), ele consegue suprimir toda e qualquer manifestação do lipocromo [SIL87].

Desconsiderando o fator que determina a tonalidade do amarelo, para os três fenótipos abaixo pode-se ter os seguintes genótipos [SIL87]:

\begin{tabular}{|l|l|}
\hline Lipocrômicos & $\frac{\mathrm{bd}}{\mathrm{bd}} \frac{\mathrm{BR}}{\mathrm{BR}}, \frac{\mathrm{bd}}{\mathrm{bd}} \frac{\mathrm{BR}}{\mathrm{br}}$ \\
\hline Branco dominante & $\frac{\mathrm{BD}}{\mathrm{Bd}} \frac{\mathrm{BR}}{\mathrm{BR}}, \frac{\mathrm{BD}}{\mathrm{bd}} \frac{\mathrm{BR}}{\mathrm{br}}, \frac{\mathrm{BD}}{\mathrm{BD}} \frac{\mathrm{BR}}{\mathrm{BR}}, \frac{\mathrm{BD}}{\mathrm{BD}} \frac{\mathrm{BR}}{\mathrm{br}}$ \\
\hline Branco recessivo & $\frac{\mathrm{bd}}{\mathrm{bd}} \frac{\mathrm{br}}{\mathrm{br}}, \frac{\mathrm{BD}}{\mathrm{bd}} \frac{\mathrm{br}}{\mathrm{br}}, \frac{\mathrm{BD}}{\mathrm{BD}} \frac{\mathrm{br}}{\mathrm{br}}$ \\
\hline
\end{tabular}

\subsubsection{O Fator para Vermelho}

O pássaro Tarim utilizado na hibridação com canários possui dois genes que produzem a cor final vermelha, o vermelho e o amarelo, e esta combinação é transmitida em conjunto. Esses genes possibilitam a assimilação pelo lipocromo da cor vermelha resultante de alguns carotenóides contidos nos alimentos ou sintetizados. O locus para o gene responsável pelo vermelho se encontra no mesmo cromossomo em que está o locus que define a tonalidade do amarelo [SIL87].

Considerando $\underline{\mathrm{V}}$ para o gene que foi incorporado ao patrimônio do canário e $\underline{\mathrm{y}}$ seu alelo inativo, todos os canários terão em seu patrimônio genético, em dois loci do mesmo autossomo, duas das combinaçסes: $A / A, A / a, a / a, V / V, V / v, v / v$. Somente os pássaros que possuírem $V$ terâo possibilidade de assimilar a cor vermelha. As combinações resultantes dos quatro genes é que 
determinarão a maior ou menor possibilidade de assimilação da cor vermelha, variando a intensidade das cores de acordo com o quadro abaixo [SIL87]:

\begin{tabular}{|l|l|l|l|l|l|}
\hline $\begin{array}{l}\text { av } \\
\text { av }\end{array}$ & $\begin{array}{l}\text { Amarelo muito claro, } \\
\text { tendendo ao branco }\end{array}$ & $\frac{\mathrm{aV}}{\mathrm{av}}$ & $\begin{array}{l}\text { Vermelho } \\
\text { Heterozigoto }\end{array}$ & $\frac{\mathrm{AV}}{\mathrm{AV}}$ & Laranja \\
\hline$\underline{\mathrm{Av}}$ & Amarelo médio & $\frac{\mathrm{AV}}{\mathrm{av}}$ & Laranja heterozigoto & $\frac{\mathrm{AV}}{\mathrm{aV}}$ & Laranja avermelhado \\
\hline$\frac{\mathrm{Av}}{\mathrm{Av}}$ & Amarelo vivo & $\frac{\mathrm{AV}}{\mathrm{AV}}$ & Amarelo alaranjado & $\frac{\mathrm{aV}}{\mathrm{aV}}$ & Vermelho vivo \\
\hline
\end{tabular}

Os pássaros de genótipo aV/av e aV/aV são os de maior capacidade de assimilação [SIL87].

\subsubsection{O Canário Albino}

Variedades de brancos perderam o pigmento em sua plumagem mas não são albinos, pois ainda retêm o pigmento em outras partes do corpo como os olhos, bicos e pés. No canário albino, todo pigmento escuro está ausente, tornando os olhos vermelhos (devido aos vasos sangǘneos) e apresentando ausência total do lipocromo. $O$ pássaro é branco puro na sua aparência. $O$ bico é de cor clara, quase transparente e o tom avermelhado tinge pés e dedos [MAT92].

Há também os albinos não isentos de carotenóides. A coloração amarela ou vermelha é controlada por outros pares de genes autossomais que permitem a metabolização e a fixação dos carotenóides, de origem vegetal e ingeridos através dos alimentos, na plumagem. Sendo assim, os exemplares amarelos ou vermelhos de olhos vermelhos podem ser considerados albinos, mas devido aos seus lipocromos são denominados de Lutinos e Rubinos, respectivamente [SEI96b].

Em qualquer um dos casos (Albino, Lutino ou Rubino), sabe-se que esses pássaros podem possuir dois tipos de genótipos diferentes apresentando o mesmo fenótipo. A diferença é que um possui os genes para olhos vermelhos em um autossomo, sendo por isso considerado um albino autêntico, e o outro possui tais genes no cromossomo ligado ao sexo, sendo considerado fenocópia do primeiro exemplar. Abaixo, são apresentados exemplos dos dois tipos possiveis de genótipos para o albino, ambos possuindo o par e/e, que impede qualquer manifestação melânica na plumagem e partes córneas e br/br, par de cromossomos que exerce epistasia sobre os demais pares de genes ligados à coloração, impedindo qualquer manifestação lipocrômica na plumagem [SEI96b]: 


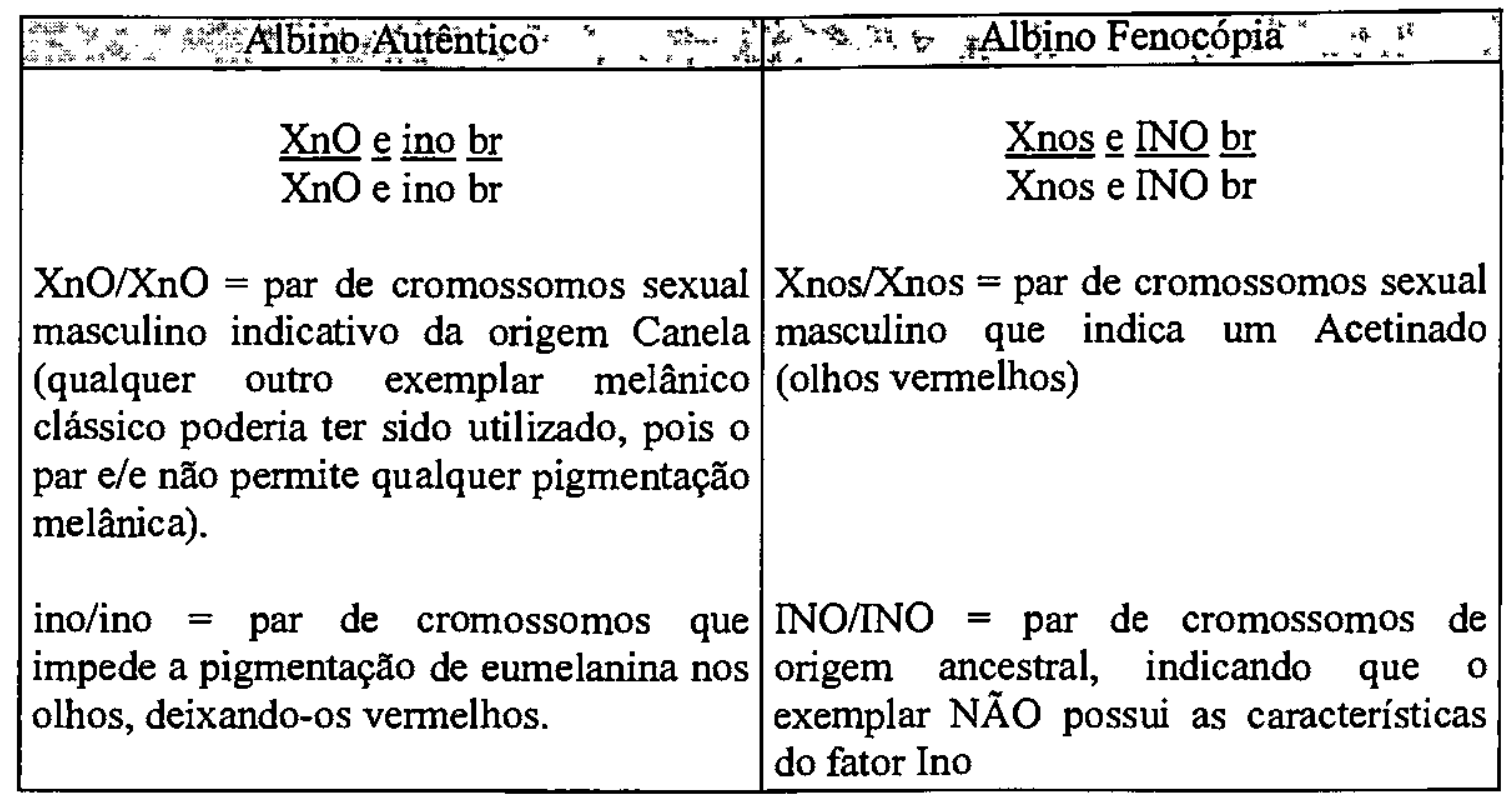

Fenotipicamente não há nenhuma forma de se diferenciar um albino do outro, mas sabese que a grande maioria dos albinos existentes atualmente não são autênticos, e sim fenocópias, pois sendo autossomal, para se obter um albino autêntico seria necessário uma fêmea portadora de ino para obter filhotes de olhos vermelhos na primeira descendência, enquanto que usando um macho Albino Acetinado, que é sexo-ligado, já se obtêm olhos vermelhos no primeiro acasalamento com qualquer fêmea branca [SEI96b]. Análise semelhante é válida para os Lutinos e Rubinos.

\subsubsection{A Mutação Canela}

Os pássaros canelas ou oxidados apresentam uma mutação no gene $\underline{\mathrm{N}}$, cuja função é assegurar a formação de melaninas negras e marrons. Por um motivo qualquer, esse gene perdeu seu potencial e parte do processo que permitia que fosse atingido o estágio final dos pigmentos melânicos foi suprimido de sua ação. Assim, o gene mutante n permite o depósito das melaninas marrons periféricas e o depósito das melaninas concentradas no eixo das plumas. A presença do gene mutante faz com que as melaninas do eixo permaneçam marrons, pois não sofrem o processo de polimerização que caracteriza as melaninas negras no canário ancestral [SIL87].

Como os genes estão situados em um locus do cromossomo sexual, somente os machos podem se apresentar em estado de heterozigose. Como o gene $\underline{\mathrm{N}}$ é dominante em relação ao mutante $\underline{n}$, apenas os fenótipos verde e canela serão observados [SIL87]: 


\begin{tabular}{|l|c|l|c|}
\hline Macho verde & $\frac{\mathrm{XNO}}{\mathrm{XNO}}$ & Fêmea verde & $\frac{\mathrm{XNO}}{\mathrm{Y}}$ \\
\hline $\begin{array}{l}\text { Macho verde, portador de } \\
\text { canela }\end{array}$ & $\frac{\mathrm{XNO}}{\mathrm{XnO}}$ & - & - \\
\hline Macho canela & $\frac{\mathrm{XnO}}{\mathrm{XnO}}$ & Fêmea canela & $\frac{\mathrm{XnO}}{\mathrm{Y}}$ \\
\hline
\end{tabular}

\subsubsection{A Mutaçăo Ágata}

Os canários ágata apresentam os pigmentos negro e canela diluídos. A diluição do pigmento negro causa uma redução na sua área de atuação, manifestando-se em bastões estreitos e muito bem marcados. Apresentam as bordas das rêmiges, retrizes, das plumas, do dorso e do flanco (região abdominal lateral) de uma tonalidade cinza-pérola [SIL87].

A mutação ocorreu no gene $\underline{\mathrm{O}}$ que deixou de depositar as melaninas desde o início do crescimento das penas. Assim, as penas do mutante passaram a apresentar uma menor quantidade de melaninas nas extremidades, e em alguns casos, a ausência total das mesmas. A melanina marrom que normalmente é depositada no início do crescimento da pluma também desapareceu. O gene mutante é representado por oa, é recessivo e, como na mutação canela, também se situa em um locus do cromossomo sexual, possibilitando heterozigose somente em machos [SIL87]:

\begin{tabular}{|l|c|l|c|}
\hline Macho verde & $\frac{\mathrm{XNO}}{\mathrm{XNO}}$ & Fêmea verde & $\frac{\mathrm{XNO}}{\mathrm{Y}}$ \\
\hline $\begin{array}{l}\text { Macho verde, portador de } \\
\text { ágata }\end{array}$ & $\underline{\mathrm{XNO}}$ & - & - \\
\hline Macho ágata & $\frac{\mathrm{XNoa}}{\mathrm{XNNoa}}$ & Fêmea ágata & $\frac{\mathrm{XNoa}}{\mathrm{Y}}$ \\
\hline
\end{tabular}

\subsubsection{O Canário Isabelino}

O canário isabelino surgiu não de uma mutação, mas da transferência do gene oa para os canários canelas. Isto foi feito através do acasalamento de uma fêmea canela com um macho ágata. As fềmeas geradas foram todas ágatas e os machos possuíam o genótipo $\frac{X n o a}{X n O}$ e fenótipo negro marrom oxidado (verde, cobre ou azul), exemplificado no quadro abaixo [SIL87]:

\begin{tabular}{|c|c|c|}
\hline Macho Fêmea & $\mathrm{XnO}$ & $\mathrm{Y}$ \\
\hline $\mathrm{XNNoa}$ & $\frac{\mathrm{XNoa}}{\mathrm{XnO}}$ & $\frac{\mathrm{XNoa}}{\mathrm{Y}}$ \\
\hline $\mathrm{XNNo}$ & $\frac{\mathrm{XNoa}}{\mathrm{XnO}}$ & $\frac{\mathrm{XNoa}}{\mathrm{Y}}$ \\
\hline
\end{tabular}


Como se trata de genes de um mesmo cromossomo, há a possibilidade de recombinação (ou crossing-over), que neste caso pode ocorrer com certa freqüência, pois os loci envolvidos se encontram relativamente afastados no cromossomo. Um esquema simplificado do que ocorre na meiose pode ser visto na figura 3.5 [SIL87].

O canário isabelino macho é representado por $\frac{X n o a}{X n o a}$ e a fềmea por $\frac{X n o a}{Y}$ [SIL87].

Esses canários negros marrons oxidados que têm possibilidade de produzir fềmeas verdes, canelas, ágatas e isabelinas são classificados como chave-mestra, ou passe-partout. Há dois tipos de passe-partout, o que foi descrito acima, representado por $\frac{X N o a}{X n O}$ é denominado tipo II ou Trans, pois em cada cromossomo existe um alelo mutante e um primitivo. O outro tipo, denominado Cis ou tipo I possui os genes mutantes num mesmo cromossomo homólogo e se origina do acasalamento de pássaros isabelinos com verdes, cujo genótipo é $\frac{X n o a}{X N O}$. Com relação ao fenótipo esses pássaros não possuem diferença alguma. Entretanto, os gametas parentais (aqueles idênticos aos recebidos dos pais) gerados durante a meiose serão diferentes. No tipo I aparecerão o isabelino (Xnoa) e o verde (XNO), enquanto que no tipo Il surgirão o ágata (XNoa) e o canela (XnO). Pode-se observar que para cada um dos casos os gametas recombinantes de um são os parentais do outro e vice-versa [SIL87].

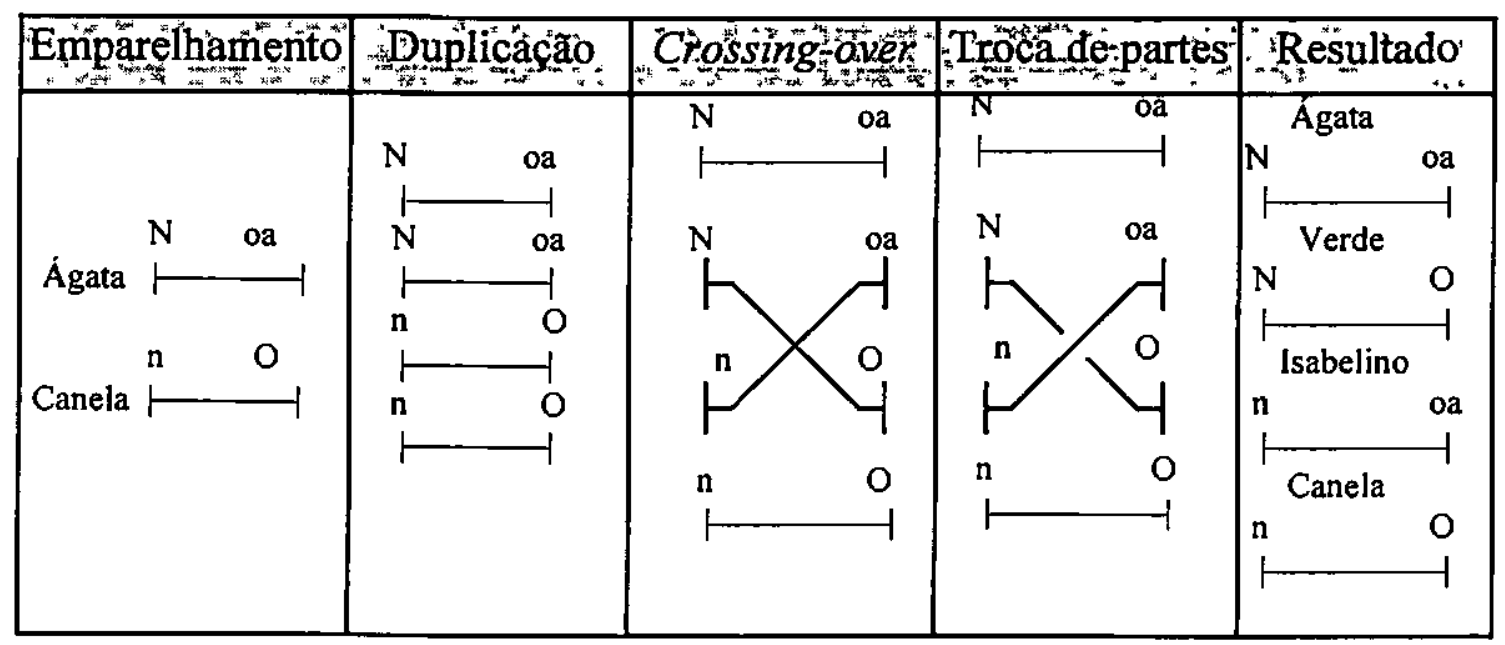

Figura 3.5 - Genótipos gerados durante a meiose no acasalamento de ágata com canela [SIL87].

O número de recombinantes nos casos extremos onde os loci estão muito separados uns dos outros é igual, no máximo, ao número de gametas parentais. Nos casos em discussão há uma ligeira diferença entre os fenótipos parentais e recombinantes quando considerada uma 
amostragem significativa. Como média é válido considerar que para cada três parentais surjam dois recombinantes [SIL87].

Assim, o passe-partout tipo I, considerando uma amostragem significativa, produz cerca de $40 \%$ de gametas recombinantes (ágata e canela) enquanto no tipo II a situação se inverte, ou seja, o maior número será de gametas para essas cores. Há outros canários que podem também ser considerados passe-partout, entre eles o negro marrom oxidado ou diluído portador de acetinado típico [SIL87].

\subsubsection{O Fator Marfim}

O fator marfim altera a aparência do lipocromo diluindo-o, fazendo com que a intensidade normal da coloração seja reduzida pela metade. A tonalidade é uniforme dando um tom marfim aos canários amarelos e rosa aos canários que possuem cor de fundo vermelha. $\mathrm{A}$

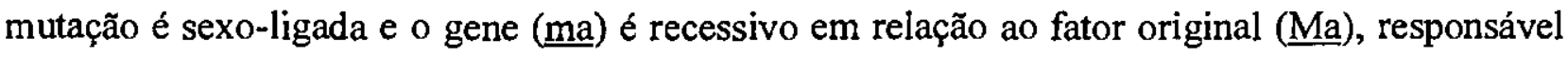
pela deposição normal do lipocromo na plumagem [SIL87].

Os genótipos e fenótipos possiveis são:

\begin{tabular}{|l|c|l|c|}
\hline Macho normal & $\frac{\mathrm{XMa}}{\mathrm{XMa}}$ & Fêmea normal & $\frac{\mathrm{XMa}}{\mathrm{Y}}$ \\
\hline $\begin{array}{l}\text { Macho normal } \\
\text { portador de marfim }\end{array}$ & $\frac{\mathrm{XMa}}{\mathrm{Xma}}$ & - & - \\
\hline Macho marfim & $\frac{\mathrm{Xma}}{\mathrm{Xma}}$ & Fêmea marfim & $\frac{\mathrm{Xma}}{\mathrm{Y}}$ \\
\hline
\end{tabular}

Essa mutação causa uma modificação na estrutura das penas através do aumento da espessura da camada de queratina. O canário marfim possui o lipocromo amarelo somente nas bárbulas, reduzindo, assim, a intensidade da cor. Além disso, a camada de queratina mais espessa reduz a visibilidade da cor dando uma impressão de marfim. $O$ fator pode aparecer em pássaros da linha clara e também da linha escura, variando as tonalidades [MAT92].

\subsubsection{O Fator Pastel}

Conhecido também como segundo fator de diluição das melaninas (o primeiro é o fator ágata), o fator pastel é sexo-ligado, mas não se tem certeza da posição exata do gene no cromossomo. Esta mutação afeta tanto as melaninas negras como as marrons, sejam elas concentradas ou periféricas [SIL87].

A alteração na pigmentação existente nos pássaros com fator pastel é produzida por um crescimento anormal dos órgãos melânicos dentro dos melanócitos que praticamente explodem, impedindo, após um período de deposição normal (pontas das asas), que as melaninas sejam depositadas nas quantidades devidas [OBJ96]. 
O gene primitivo para uma pigmentação normal, representado por $\underline{\mathrm{P}}$ é dominante em relação ao seu alelo mutante, $\underline{p}$, que determina o fenótipo pastel [SIL87]:

\begin{tabular}{|l|l|l|c|}
\hline Macho normal & $\frac{\mathrm{XP}}{\mathrm{XP}}$ & Fêmea normal & $\frac{\mathrm{XP}}{\mathrm{Y}}$ \\
\hline $\begin{array}{l}\text { Macho normal, } \\
\text { portador de pastel }\end{array}$ & $\frac{\mathrm{Xp}}{\mathrm{XP}}$ & - & - \\
\hline Macho pastel & $\frac{\mathrm{Xp}}{\mathrm{Xp}}$ & Fêmea pastel & $\frac{\mathrm{Xp}}{\mathrm{Y}}$ \\
\hline
\end{tabular}

\subsubsection{O Fator Opalino}

$O$ primeiro fator a surgir com influência no desenho melânico e não sexo-ligado foi o opalino. Os canários opalinos possuem pigmentos melânicos bastante reduzidos, estrias cinzaazuladas ao invés de negras e a melanina marrom da plumagem é praticamente ausente [SIL87].

Essa mutação ocorreu através da modificação no arranjo das barbas nas penas. As barbas são compostas por quatro camadas. A mais externa, a camada cómea, envolve o córtex, que tem um núcleo envolvido por uma parede transparente. Normalmente a melanina, os pigmentos negros e marrons, são encontrados no córtex e principalmente na parte mais externa, tornando a pena mais escura do lado de fora do que do lado de dentro. No canário opalino alguma melanina aparece também no núcleo, mas o resto dela é "revertida", ficando principalmente do lado de dentro do córtex. A luz atinge os pigmentos mais escuros nas partes mais internas das penas mostrando, assim, as cores como se vistas através de um vidro leitoso, como a pedra preciosa opala [MAT92].

Sendo uma mutação autossomal, há portadores dos dois sexos. O fenótipo recessivo só se expressa quando em dose dupla [SIL87].

As representações utilizadas para esses pássaros são:

\begin{tabular}{|l|c|}
\hline Não Opalino & $\frac{\overline{O P}}{\mathrm{OP}}$ \\
\hline Portador de Opalino & $\frac{\mathrm{OP}}{\mathrm{op}}$ \\
\hline Opalino & $\frac{\mathrm{op}}{\mathrm{op}}$ \\
\hline
\end{tabular}

\subsubsection{O Fator Ino}

A mutação ino surgiu na progênie de um casal isabelino vermelho. $O$ fenótipo desta versão pode ser facilmente confundido com um lipocrômico vermelho ou um pastel isabelino vermelho com muito pouca difusão de marrom. Apresenta, porém, olhos vermelhos e brilhantes, que não alteram sua cor com o desenvolvimento do pássaro [SIL87]. 
Este fator inibe totalmente as melaninas negras, permitindo apenas o depósito das melaninas marrons periféricas. A principal característica dos inos é o contraste entre a melanina cor de chocolate e a cor de fundo. No entanto, as fêmeas apresentam-se com maior carga melânica do que os machos, pois os hormônios feminizantes favorecem o depósito das feomelaninas [SIL87].

O fator ino é autossomal e acredita-se que o gene se situa no mesmo autossomo do fator enzima (E), embora não haja certeza com relação a isso. O fator primitivo, $\underline{\mathbb{N} O}$, é totalmente dominante em relação ao seu mutante ino, portanto somente dois fenótipos são observados:

\begin{tabular}{|c|c|c|}
\hline Ino & Portador de Ino & Não ino \\
\hline$\stackrel{\text { ino }}{\text { ino }}$ & $\frac{\mathrm{INO}}{\text { ino }}$ & $\frac{\mathrm{INO}}{\mathrm{INO}}$ \\
\hline
\end{tabular}

Os pássaros oxidados que apresentam esta mutação, conhecidos como "feos" não apresentam estrias nem penas de cores escuras. A feomelanina ao longo das extremidades das penas aparece como um padrão variado no dorso. Quanto mais forte o marrom, mais escuro o padrão. O olhos são de cor vermelha [MAT92].

\subsubsection{O Fator para o Azul}

Os canários azuis são, na verdade, verdes com fundo branco dominante ou branco, com o fator azul. $O$ fator azul é uma cor estrutural, mas precisa ser completamente intenso no canário azul [MAT92].

A cor azul, que torna o lipocromo amarelo em limão, é causada pelos reflexos azulados produzidos pela reflexão das ondas de pequeno comprimento (azuis e violetas) que compõem a luz branca incidente. $O$ efeito azul depende da combinação de vários fatores: a modificação da estrutura das plumas, a relação entre as melaninas negras e marrons, os fatores não influenciáveis geneticamente e finalmente a influência dos fatores redutores dos carotenóides [SIL87].

O fator ótico para o azul é autossomal e semi-dominante. Utilizando $\lfloor$ para o fator que comanda a estrutura normal e $\underline{\underline{L}}$ o fator para o azul, os fenótipos e genótipos possiveis são [SIL87]:

\begin{tabular}{|l|c|}
\hline Normal & Il \\
\hline Meio limão & IL \\
\hline Limão & LL \\
\hline
\end{tabular}




\subsubsection{O Fator Acetinado}

O fator acetinado, assim como o fator ino, produz pássaros com olhos vermelhos, mas afeta partes distintas do desenho melânico. As melaninas negras são inibidas na parte aparente da plumagem, mas as melaninas marrons se depositam normalmente.Este fator é sexo-ligado e há uma tendência em considerá-lo como um segundo mutante do fator $\underline{\mathrm{O}}$ que produz os pássaros oxidados. O primeiro mutante da série é o fator oa, responsável pelos ágatas e isabelinos e o fator acetinado (os) seria o responsável pelos acetinados diluídos (negro-marrons) e os típicos (marrons). Estes três genes $(\underline{O}, \underline{\text { oa }}$ e $\underline{o s})$ constituem o que se conhece por série alelomórfica, ou seja, o gene original possui mais de um mutante no mesmo locus [SIL87].

Como somente dois genes podem ocupar os loci dos cromossomos homólogos, podem-se ter as seguintes combinações: $\mathrm{O} / \mathrm{O}, \mathrm{O} / \mathrm{oa}, \mathrm{O} / \mathrm{os}$, oa/oa, oa/os e os/os. O gene os responsável pelo acetinado é recessivo em relação aos outros genes da série [SIL87].

A figura 3.6 apresenta os filhotes machos resultantes dos cruzamentos de um macho acetinado típico homozigoto com fêmeas de seis tipos diferentes e os gametas possiveis de serem formados por esses filhotes. A barra utilizada na terceira coluna significa "portador de".

Os machos negro-marrons oxidados ou diluídos, portadores de acetinado típico, se comportam como passe-partout para quatro variedades. Assim, o macho verde /acetinado típico $\frac{N O}{n o s}$ tem possibilidade de produzir fêmeas verdes (NO), acetinadas típicas (nos) e por crossingover canelas (nO) e acetinadas diluídas (Nos) [SIL87].

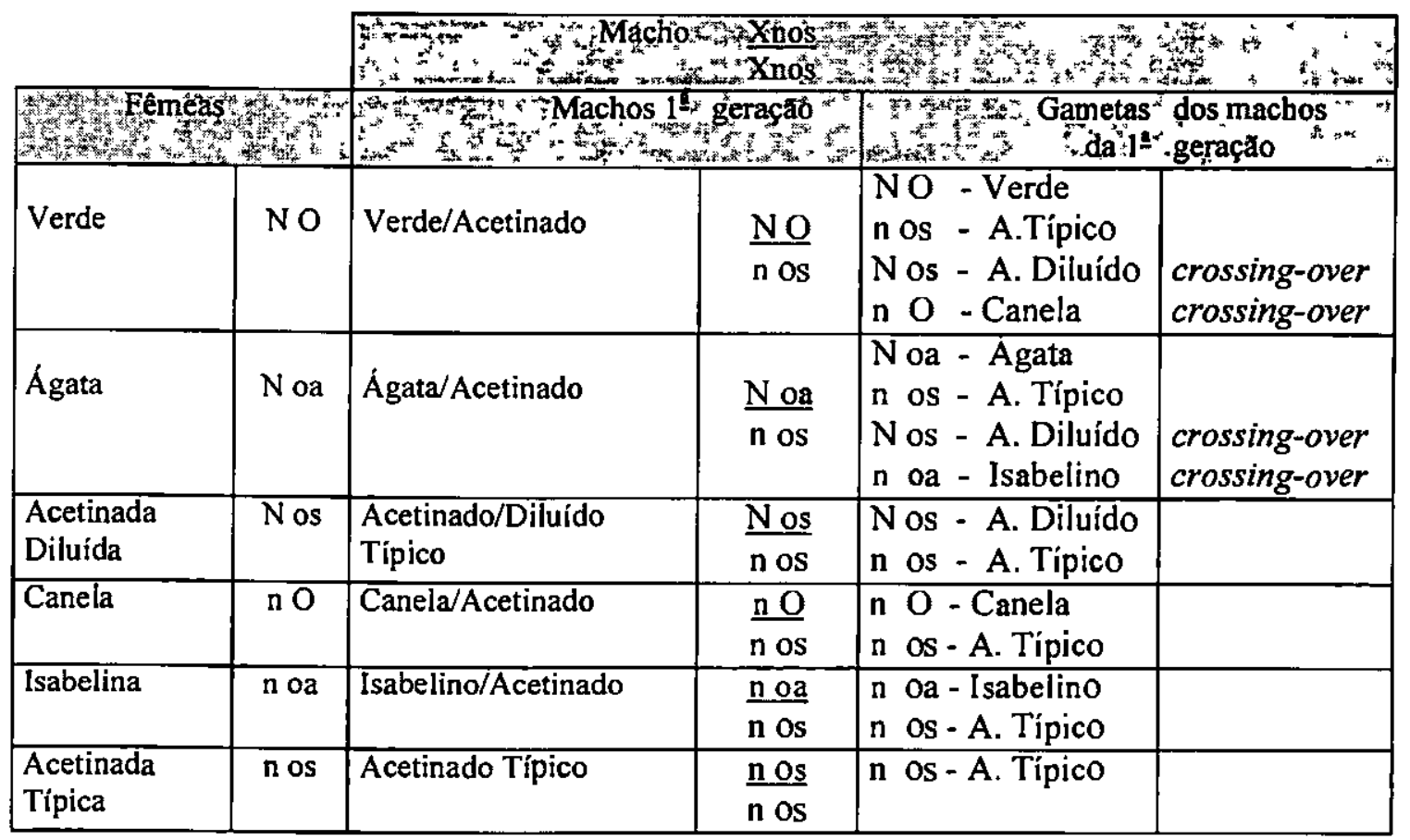

Figura 3.6 - Cruzamentos de macho acetinado com tipos diferentes de fêmeas [SIL87]. 


\subsubsection{O Fator Mosaico}

O fator mosaico só se manifesta após a primeira muda das penas, o que corresponde à puberdade dos pássaros. As zonas coloridas com lipocromo são mais extensas no macho do que nas fêmeas, caracterizando o dimorfismo sexual. O fator mosaico pode ser aplicado aos canários tanto da linha clara como da linha escura, sendo os últimos os mais difundidos atualmente. Não há certeza com relação ao tipo de cromossomo em que o gene está localizado, mas os cruzamentos levam a acreditar que um gene autossomal é o responsável pela distribuição do lipocromo nas zonas índice, isto é, as zonas onde o lipocromo permanece após a primeira muda [SIL87].

Os padrões para os mosaicos aceitos pela Ordem Brasileira de Juizes de Ornitologia (OBJO) são:

\begin{tabular}{|lllll|}
\hline $\begin{array}{l}\text { Máscara facial de cor intensa, } \\
\text { ininterrupta, bem delimitada e bem } \\
\text { destacada do peito. }\end{array}$ & $\begin{array}{l}\text { Linha dos olhos prolongada por um traço } \\
\text { curto e bem delimitado }\end{array}$ \\
\hline $\begin{array}{l}\text { Presença de lipocromo intenso nos } \\
\text { encontros e uropígio }\end{array}$ & $\begin{array}{l}\text { Presença de lipocromo intenso nos } \\
\text { encontros e uropígio }\end{array}$ \\
\hline Peito e dorso o mais branco possível & $\begin{array}{l}\text { Todo o resto do corpo branco gesso, } \\
\text { podendo apresentar uma ligeira coloração } \\
\text { lipocrômica no peito }\end{array}$ \\
\hline
\end{tabular}

O gene mo é responsável pelo surgimento do padrão mosaico quando ocorre em dose dupla e é recessivo em relação ao seu alelo $\underline{\mathrm{MO}}$ que bloqueia o aparecimento do padrão. Assim, os genótipos possíveis são [SIL87]:

\begin{tabular}{|c|c|c|}
\hline Mosaico & Portador de mosaico & Não mosaico \\
\hline$\underline{\mathrm{mo}}$ & $\frac{\mathrm{MO}}{\mathrm{mo}}$ & $\frac{\mathrm{MO}}{\mathrm{MO}}$ \\
\hline
\end{tabular}

\subsubsection{O Canário Asa Cinza}

Os canários "asas cinza" têm sua origem nos "pastéis" negro-marrom oxidados, que por efeito da "dupla diluição" apresentam forte despigmentação na região central das rêmiges e retrizes, formando uma faixa cinza perolada com tendência ao branco. A "dupla diluição" também afeta toda a plumagem dando ao desenho uma aparência de escamação cinza perolada. As estrias características dos "pastéis" negro-marrons desaparecem, surgindo em seu lugar um escamado uniforme. Os bicos e pés são escuros [COR96]. 
Geneticamente, é uma mutação sexo-ligada recessiva e forma uma série alelomórfica com o gen original que caracteriza a cor negro-marrom oxidado, com o gen pastel que caracteriza a cor negro-marrom oxidado pastel e com o gene asas cinza, que define o padrão asas-cinza [SEI96a].

Os primeiros pássaros asas cinza que surgiram eram fêmeas, obtidas através do acasalamento entre um negro marrom oxidado portador de pastel isabelino com uma fêmea pastel isabelina. O cruzamento entre um macho deste acasalamento (negro marrom oxidado) com fêmeas asas cinza conduziu aos machos asas cinza. Exemplificando [SIL87]:

\begin{tabular}{|c|c|l|l|}
\hline \multicolumn{2}{|c|}{ Fêmea Pastel Isabelina (n oa p) X Macho Negro-Marrom Oxidado (N O P) } \\
\hline \multicolumn{2}{|c|}{ Machos 1 $1^{\mathrm{a}}$ geração } & \multicolumn{1}{|c|}{ Gametas dos machos da $1^{\mathrm{a}}$ geração } \\
\hline $\begin{array}{c}\text { Negro-marrom oxidado } \\
\text { portador de pastel isabelino }\end{array}$ & $\underline{\mathrm{N} \mathrm{O} \mathrm{P}}$ & $\begin{array}{l}\text { N O P - Negro-marrom } \\
\text { oxidado } \\
\text { n oa p - Pastel isabelino } \\
\text { N O p - Negro-marrom pastel } \\
\text { n oa P - Isabelino pastel }\end{array}$ & $\begin{array}{l}\text { crossing-over } \\
\text { crossing-over }\end{array}$ \\
\hline
\end{tabular}

Somente por crossing-over entre $\mathrm{P}$ e p é que se pode obter o macho negro-marrom pastel $\frac{X N O p}{\text { Xnoap }}[$ SIL87].

Teoricamente o cruzamento entre os indivíduos negro-marrons da $2^{\mathrm{a}}$ geração só daria lugar aos pastéis negro-marrons oxidados, mas foi constatado que o cruzamento de um indivíduo pastel negro-marrom oxidado deste acasalamento com uma de suas irmãs asa cinza produziu machos asas cinza, podendo-se admitir que ocorreu uma modificação com o fator pastel do macho utilizado na $2^{\underline{a}}$ geração e que este tenha produzido as fêmeas asas cinza e machos portadores do fator. Quando utilizaram um desses portadores surgiram os machos asas cinza.

Considerando-se a representação $p$ para o gene modificado, se um dos machos utilizados tivesse por genótipo $\frac{X N O P}{X \text { noap }}$ e uma fêmea asa cinza $\frac{X N O p}{Y}$ os machos asas cinza seriam viáveis [SIL87].

Existe a hipótese de que tenha havido uma duplicação do gene pastel durante a meiose, isto é, a ruptura de um segmento do cromossomo que contém o gene e a ligação deste segmento a um outro cromossomo. Assim, este cromossomo a duplo fator pastel seria o responsável pelos asas cinza. Este fato provocaria um freamento brutal na melanização após um determinado tempo, enquanto o fator pastel provoca um freamento regular e progressivo[SIL87]. 
O cromossomo sexual, responsável pelos asas cinza pode ser representado como XNOpp. $\mathrm{O}$ acoplamento pode ser desfeito no novo indivíduo em outra meiose, podendo surgir um macho pastel do acasalamento entre um asa cinza e uma fêmea normal. O surgimento de pastéis é constante no acasalamento entre asas cinza como também ocorre o surgimento de asas cinza no acasalamento entre pastéis [SIL87].

\subsubsection{O Canário Topázio}

Os canários topázio caracterizam-se pela modificação da produção da eumelanina e pela sua concentração ao redor do canal medular das penas, fazendo com que apareçam largos contornos claros nas grandes plumas. Nos negro-marrons o desenho clássico se apresenta na cor chocolate escuro. Os bicos e patas do pássaro possuem cor de carne e os olhos são negros. Já nos ágatas o desenho se torna mais claro, fino e curto. A feomelanina é o mais reduzida possível e os contornos das penas são amplos e claros, bicos e patas claros e olhos negros [COR96].

A mutação topázio ainda não foi totalmente esclarecida. Existe a hipótese de que o gene causador da mutação seja um outro alelo mutante do fator INO. Dessa forma, haveria uma série alelomórfica constituída de três alelos $\underline{\mathbb{N} O}$, $\underline{\text { zz }}$ e ino em um mesmo locus. A dominância é total do gene primitivo (INO) sobre os dois alelos mutantes, mas é parcial entre $\underline{\mathrm{tz}}$ e $\underline{\text { ino }}$ e o indivíduo que possuir no locus os dois mutantes $\underline{\mathrm{tz}} \mathrm{e}$ ino apresentará um fenótipo intermediário entre o topázio (tz/tz) e ino (ino/ino) [SIL87].

O gene é autossomal e os genótipos e fenótipos possiveis são:

\begin{tabular}{|c|c|c|c|}
\hline Normal +5 & INO / INO & Fopázión & $\mathrm{tz} / \mathrm{tz}$ \\
\hline Normal/topázió & $\overline{\mathrm{INO} / \mathrm{tz}}$ & Intermediário & tz/ino \\
\hline Normal / ino + s & Ino / ino & 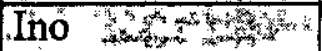 & ino/ino \\
\hline
\end{tabular}

\subsection{Consideraçōes Finais}

Uma grande variedade de cores apareceram no decorrer dos anos através das mutações, criações seletivas e até mesmo hibridações. A diversidade fenotípica leva às 358 cores classificadas atualmente pela $\mathrm{OBJO}^{*}$. Além dos fenótipos reconhecidos oficialmente, existe ainda uma extensa relação de fenótipos excluídos da nomenclatura oficial, entre eles os canários Branco Marfim e os Amarelo Laranja, além dos canários pintados.

\footnotetext{
A nomenclatura oficial das cores aceitas pela Ordem Brasileira de Juizes de Ornitologia e seus respectivos códigos são descritos no Apêndice $B$.
} 
Uma das fontes da extensa variabilidade genética para o cor observada nos canários é a possibilidade de combinação das diferentes cores de fundo com uma mesma cor de cobertura. Este fenômeno, no entanto, só ocorre nos canários pertencentes à linha escura.

Os principais fatores que levaram ao grande número de cores existentes nos canários, partindo do canário verde acinzentado original são: a mutação gênica que originou os canários Amarelo e Branco, a permutação cromossômica que originou os canários isabelinos, o cruzamento e seleção direcional que originou os canários azuis e finalmente a hibridação, que deu origem aos canários de cor vermelha e aos mosaicos. 


\section{O Conhecimento Avançado}

\subsection{Introdução}

No capítulo 3 foram vistas as diversas mutações genéticas e hibridações ocorridas em canários registradas até o momento. No entanto, para que um pássaro tenha uma boa classificação em um concurso, a observação de fórmulas genéticas para se obter a cor desejada não é suficiente. $\mathrm{Na}$ verdade, em termos de pontuação, a cor é responsável por apenas $50 \%$ do total de pontos que um canário pode obter. Uma grande quantidade de detalhes também deve ser levada em consideração, como a forma, plumagem, tamanho, elegância e outras condições gerais que podem desclassificar um pássaro por melhor que seja a qualidade da cor apresentada.

Alguns exemplos preliminares desses detalhes, denominados aqui por Conhecimento Avançado, serão vistos neste capítulo. Após a introdução do conhecimento básico, constituído pelas fórmulas genéticas para a cor, informações que fazem parte do Conhecimento Avançado serão inseridas gradualmente na Base de Conhecimento, e terão como função principal aconselhar o criador de canários a utilizar em acasalamentos somente pássaros que estejam dentro dos padrões determinados pela Ordem Brasileira de Juizes de Ornitologia.

As informações sobre o Conhecimento Avançado, diferentemente do Conhecimento Básico, nem sempre estão registradas em livros cuja especialidade é a canaricultura. Na verdade, as informações se encontram espalhadas pelas revistas ornitológicas, publicações sobre eventos da área e, principalmente, no conhecimento adquirido pela prática em criação de canários pelos canaricultores.

\subsection{A Plumagem dos Canários}

Como já foi visto, os canários mosaicos apresentam dimorfismo sexual. As principais características que diferenciam os machos das fêmeas estão relacionadas com a atuação do lipocromo nas penas, descritas no quadro 4.1. As diferenças podem ser visualizadas na figura 4.1. 


\begin{tabular}{|c|c|c|}
\hline & Machos & Fêmeas \\
\hline Máscara Facial & $\begin{array}{l}\text { O lipocromo se deposita na } \\
\text { região ao redor do bico, } \\
\text { ultrapassando a parte inferior } \\
\text { deste, passando por detrás dos } \\
\text { olhos e atingindo a parte } \\
\text { média do alto da cabeça }\end{array}$ & $\begin{array}{l}\text { O lipocromo deverá ser } \\
\text { depositado apenas numa linha } \\
\text { horizontal curta na altura dos } \\
\text { olhos, não devendo se estender } \\
\text { em outras regiões }\end{array}$ \\
\hline $\begin{array}{l}\text { Encontros (Om- } \\
\quad \text { bros) }\end{array}$ & $\begin{array}{l}\text { O lipocromo deverá ser depo- } \\
\text { sitado na região dos ombros, } \\
\text { estendendo-se ligeiramente } \\
\text { para as penas longas das asas } \\
\text { (rêmiges). }\end{array}$ & $\begin{array}{l}\text { Como no macho, o lipocromo } \\
\text { deverá ocupar a região dos } \\
\text { ombros, estendendo-se ligei- } \\
\text { ramente para as rêmiges. }\end{array}$ \\
\hline Uropígio & $\begin{array}{l}\text { Região em que deverá haver } \\
\text { depósito do lipocromo }\end{array}$ & $\begin{array}{l}\text { Assim como no macho, o } \\
\text { lipocromo deverá se depositar } \\
\text { nesta região }\end{array}$ \\
\hline$=$ & $\begin{array}{l}\text { Deve obrigatoriamente apre- } \\
\text { sentar lipocromo na região } \\
\text { central do peito, não devendo } \\
\text { se estender para outras regiões } \\
\text { como flancos, pescoço e clo- } \\
\text { aca }\end{array}$ & Deve ser isento de lipocromo. \\
\hline
\end{tabular}

Quadro 4.1 - Áreas de atuação do lipocromo em Mosaicos [SEI96c].

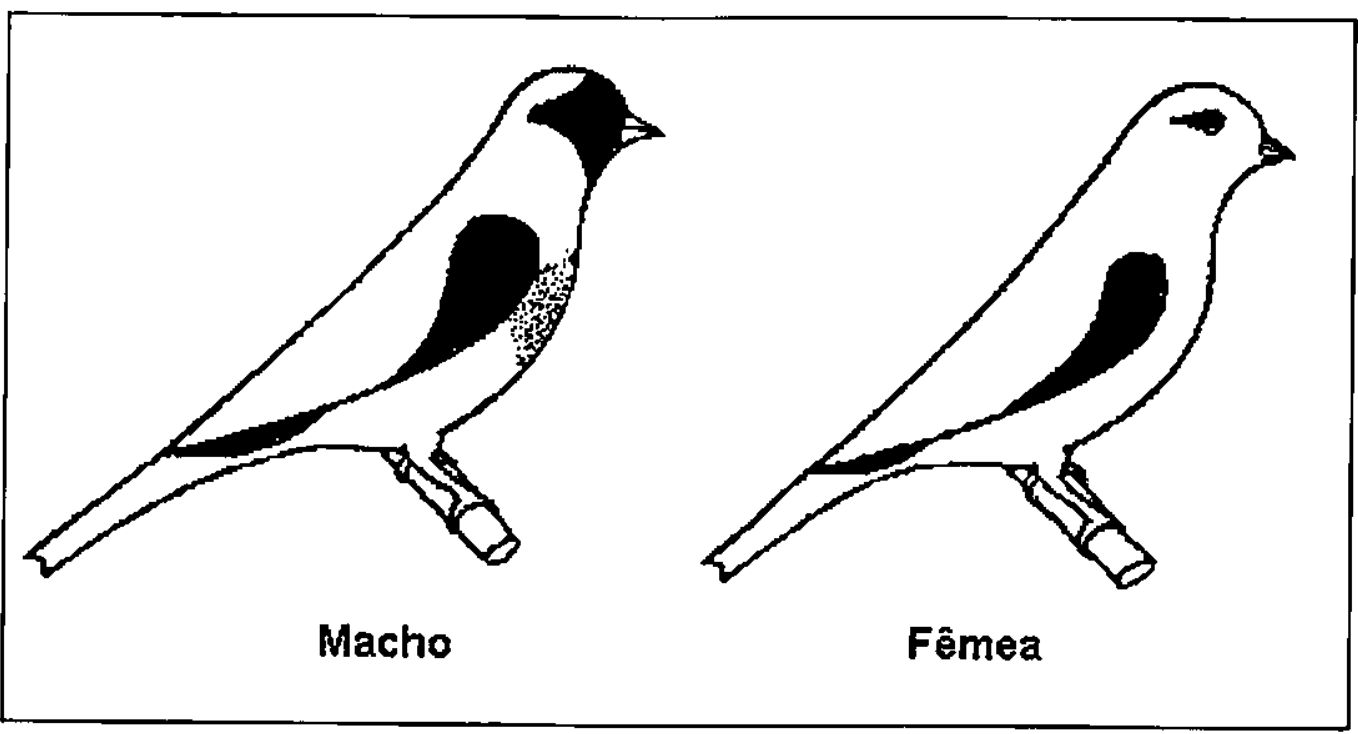

Figura 4.1 - Pássaros com ótima extensão das zonas de eleição dos lipocromos [OBJ96].

No entanto, independente do sexo do canário e de sua cor, ou seja, amarelo mosaico, vermelho mosaico, etc., as zonas de depósito de lipocromo devem se apresentar com uma intensidade bastante forte, aumentando o contraste com a cor do resto da plumagem, que por sua vez, deve ser totalmente isenta de lipocromo. Por exemplo, um canário Vermelho Mosaico deve 
possuir depósito de lipocromo vermelho vivo, com intensidade máxima, nas áreas especificas, e o resto da plumagem deve ser totalmente branca [SEI96c].

Um fator bastante importante para se atingir a cor ideal é o comprimento das penas. Os canários, em geral, podem apresentar penas curtas, médias ou longas, independente da cor que possuem. A plumagem curta é aderente ao corpo, não forma fachos laterais e não se sobrepõe aos ombros. Outros itens que evidenciam este tipo de plumagem é a secagem rápida do pássaro após o banho e também a facilidade de se observar a pele do mesmo com um pequeno sopro na região abdominal. $\mathrm{O}$ comprimento das penas está diretamente relacionado com a cor do canário, pois um canário de plumagem curta normalmente possui mais cor, enquanto que canários com plumagem de comprimento médio costumam apresentar boa forma, boa intensidade de cor e tamanho dentro de um padrão desejável. Como o comprimento da plumagem é transmitido geneticamente e, levando-se em consideração que os Mosaicos têm como característica uma plumagem mais longa que os outros tipos de canários, um cuidado especial deve ser tomado com relação ao acasalamento desses pássaros, pois [SE196c]:

- Quanto mais curtas forem as penas, maior será a concentração de lipocromo.

- Penas curtas e aderentes permitem ao exemplar exibir os ombros (encontros), proporcionando melhor contraste entre o lipocromo ali depositado e o restante da plumagem.

- Acasalamentos entre canários de plumagens longas aumenta a probabilidade do aparecimento de cistos. Isto porque o tamanho da pena influencia na sua estrutura: penas curtas são mais rígidas que penas longas, que são mais fracas. Devido a essa fraqueza, algumas penas não conseguem romper a pele, fazendo com que se desenvolvam debaixo da pele, formando os cistos.

- Acasalamentos consecutivos entre exemplares de penas curtas podem resultar filhotes muito finos, fazendo com que, em concursos, percam pontos com relação à forma. Em casos mais graves, os filhotes podem apresentar ausência de penas em algumas regiões do corpo.

Assim, é aconselhável o acasalamento de pássaros de penas curtas com aqueles de penas médias ou grandes, ou quando ambos possuírem penas médias, com o intuito de aumentar a intensidade do lipocromo e diminuir os problemas com cistos ou com falta de penas pelo corpo. Tal conhecimento se aplica não somente a Mosaicos, mas também a pássaros Intensos e Nevados [SEI96c]. 


\subsection{Os Canários Brancos}

Os canários Brancos Dominantes possuem alguns resquícios de carotenóide, normalmente localizados nas bordas das penas periféricas das asas, da cauda, encontros e outras regiões do corpo. Como as fêmeas apresentam menor incidência de lipocromo, são mais indicadas para concursos. O lipocromo pode variar do amarelo ao vermelho-laranja e marfim, mas a tonalidade amarelo-limão é a que deve prevalecer [KOB96].

Acredita-se poder obter o Branco Dominante homozigoto, devido a sua letalidade. Assim, num acasalamento Branco Dominante X Branco Dominante, 50\% dos filhotes serão Brancos, portadores de amarelo, $25 \%$ serão Amarelos homozigotos e $25 \%$ morrerão antes mesmo que os ovos sejam eclodidos [KOB96]. Outros detalhes que devem ser levados em consideração na criação de canários brancos são [KOB96]:

- O canário Amarelo Nevado utilizado no acasalamento Branco Dominante X Amarelo Nevado deve ser o mais "limão" possível e de névoa bastante aberta. Um canário deste tipo é considerado fraco para acasalamentos com amarelos intensos.

- O acasalamento Branco Dominante X Amarelo Intenso não é recomendado, pois há risco de nascerem filhotes brancos dominantes com incrustação lipocrômica mais acentuada, além de prejudicar a forma do pássaro.

- Uma vantagem no acasalamento do Branco Dominante, portador de Recessivo X Branco, é a possibilidade de se obter Recessivos, além do Dominante. Podem aparecer, no entanto, Brancos Dominantes com incrustações lipocrômicas douradas, ruins para concurso. Outra possibilidade é a de que metade dos filhotes Brancos Dominantes obtidos sejam fenocópia do Branco, ou seja, o canário é Branco Dominante, mas não apresenta incrustações de lipocromo.

- Com relação às incrustações, deve-se dar sempre preferência às de tonalidade limão. As incrustações douradas obtêm menos pontos e as laranja desclassificam um canário no concurso.

Com relação aos canários Brancos, os melhores são aqueles que possuem plumagem sedosa, lisa e aderente. A princípio, brilho e quantidade de plumas não estão diretamente relacionadas, pois a presença e ausência de brilho ocorrem tanto em canários de plumagem curta quanto longa [KOB96]. Com relação ao brilho, algumas diretrizes são importantes, como [KOB96]: 
- No acasalamento de dois Brancos, pelo menos um deve ter brilho e o outro deve ser necessariamente filho de um casal brilhante.

- Quando um dos pares não tiver muito brilho, é preferível que o macho utilizado seja brilhante.

- Ao se acasalar um Branco com Amarelo Nevado ou Mosaico, o branco deverá ser sempre brilhante.

- Na utilização de Amarelos portadores com brilho, deve ser dado preferência ao "limão" (por possuir fator óptico para o azul, possibilitando a obtenção de brancos com mais luminosidade).

- O brilho é conseguido exclusivamente através da genética, mas pode ser intensificado através de meios artificiais, como banho, sol, alimentação, óleo, sementes, etc.

Outros cuidados que devem ser observados a fim de melhorar os canários brancos com relação à plumagem e forma são [KOB96]:

- O acasalamento de pássaros com penas curtas leva a brancos com plumagem lisa, sedosa, aderente e uniforme.

- Para a obtenção de pássaros mais enxutos, podem-se acasalar brancos $\mathrm{X}$ brancos, porém, isso provoca a diminuição no tamanho dos filhotes.

- Deve-se acasalar canários que apresentem boa forma, principalmente as fêmeas.

- Filhotes de macho Branco com fêmeas Amarelas Nevadas, de boa forma, costumam apresentar as características da mãe.

\subsection{Acasalamentos de Canários de Cor}

Somente através de acasalamentos corretos é que se pode chegar às cores cadastradas e aceitas pela Ordem Brasileira de Juizes de Ornitologia. Trabalhar apenas em cima de fórmulas genéticas pode levar a um grande número de cores, entretanto, muitos exemplares apresentarão cores sem qualquer valor para concursos.

Por causa disso, vários acasalamentos são desaconselhados, pois geram pássaros atípicos ou fora da nomenclatura atual, seja na primeira geração ou nas gerações subseqüentes. Algumas diretrizes para acasalamento podem ser observadas no quadro 4.2 . 


\begin{tabular}{|l|l|}
\hline Devem ser considerados: & \multicolumn{1}{|c|}{ Devem ser evitados: } \\
\hline Linha clara X Linha clara & Com fator vermelho X Sem fator vermelho \\
\hline Linha escura X Linha escura & Linha escura X linha clara \\
\hline Sem fator X Sem fator & Diluídos X Oxidados \\
\hline Com fator X Com fator & Mosaicos X Nevados \\
\hline Nevado X Intenso & $\begin{array}{l}\text { Branco ou Branco Dominante X Com fator } \\
\text { vermelho }\end{array}$ \\
\hline Nevado X Branco Dominante & Branco Dominante X Marfim ou portador \\
\hline Nevado X Branco & Agata X Feo \\
\hline Mosaico X Mosaico & Agata X Acetinado \\
\hline Dilú́do X Diluído & Pastel X Opalino \\
\hline Oxidado X Oxidado & Pastel X Acetinado \\
\hline Mosaico X Intenso & Pastel X Feo \\
\hline & Acetinado X Feo \\
\hline & Feo X Opalino \\
\hline & Opalino X Acetinado \\
\hline & Intenso X Intenso \\
\hline & Branco Dominante X Branco Dominante \\
\hline
\end{tabular}

Quadro 4.2 - Diretrizes para acasalamento [NEI92].

Apesar de alguns acasalamentos não serem aconselháveis, ainda assim podem ser feitos visando aprimorar determinadas qualidades. Por exemplo: acasalar mosaicos da linha clara com mosaicos da linha escura, para obter mosaicos da linha escura bem caracterizados. Entretanto, esses acasalamentos devem ser feitos exclusivamente por criadores experientes e que possuam um plantel grande [NEI92].

\subsection{Consideraçōes Finais}

Neste capitulo foram vistas algumas das inúmeras regras existentes para se obter canários de qualidade. Fatores como tamanho e brilho das penas, forma do canário, sua postura, seu tamanho, além de outras características, têm grande influência na cor do canário, imprescindível para tomar um exemplar competitivo.

Há também cuidados que devem ser tomados para que acasalamentos errados não coloquem tudo a perder, como um caso citado em [KOB96], onde o próprio autor, numa infeliz experiência, acasalou Brancos com Amarelos Intensos, com a intenção de aprimorar o brilho e a

\footnotetext{
Esse acasalamento visa intensificar o lipocromo nas zonas índices dos mosaicos e reduzir o excesso de plumagem. Contudo, só depois de algumas gerações e de acasalamentos consangüíneos obtém-se bons resultados [NE192].

Nesses acasalamentos ocorre o fator letal, matando parte dos embriōes e gerando parte dos filhotes debilitados [NEI92].
} 
plumagem de seus canários. O que conseguiu, no entanto, foi prejudicar sensivelmente a forma dos pássaros, que ficaram mais esguios, tendo suas cabeças diminuídas e seus rabos e bicos aumentados de tamanho. Por causa disso, o criador teve uma perda parcial do plantel de brancos e só após três anos de trabalho conseguiu recuperá-lo.

É importante que todo o conhecimento, cientificamente comprovado ou não, seja inserido na Base de Conhecimento deste projeto, para que possa auxiliar àqueles que se dedicam à canaricultura de cor. 


\section{Processo de Desenvolvimento do Sistema}

\subsection{Introdução}

Para o desenvolvimento deste projeto foram utilizadas três ferramentas: Microsoft Access 97, Win-Prolog 3.3 e Borland C++ 5.01, utilizando o sistema operacional Windows 95 . As ferramentas foram escolhidas por atenderem bem ao propósito do projeto, ou seja, criar um sistema com interface amigável e tempo de resposta rápido, incluindo uma base de conhecimento sobre acasalamentos de canários de cor, que interage com o usuário de uma forma simples, através de perguntas justificadas e apresentação de soluções que vêm acompanhadas de textos explicativos.

A ferramenta Microsoft Access 97 fornece acesso a um banco de dados relacional, importa e exporta dados de forma fácil e eficiente, cria tabelas, consultas, formulários e relatórios automaticamente que podem ser personalizados para se adaptarem às necessidades do projeto. A ferramenta permite ainda a inserção e vinculação de objetos OLE, bastante útil para inserir as fotos dos pássaros no Cadastro de Cores.

O Borland $\mathrm{C}++5.01$ foi utilizado no desenvolvimento da rotina responsável por apresentar os resultados de um acasalamento, onde seria necessário fazer a combinação dos genótipos de um casal de canários.

\subsection{Análise de Requisitos}

O desenvolvimento do Sistema de Apoio à Criação de Canários de Cor partiu da necessidade que se tinha de um sistema que pudesse simular acasalamentos entre canários de cor, demonstrando os resultados possiveis, orientando o usuário sobre os tipos de acasalamentos que podem ou não ser praticados.

Através de entrevistas consecutivas com o usuário foi possível identificar dois grandes problemas: simulações de acasalamento e escolha do melhor parceiro.

O próximo passo foi avaliar que informações seriam necessárias para que o sistema pudesse resolver os problemas apresentados. Para solucionar o primeiro problema optou-se por desenvolver um cadastro onde seriam registradas todas as cores que são reconhecidas atualmente pela Ordem Brasileira de Juizes de Ornitologia (O.B.J.O.) e onde seriam mantidos, além de 
outras informações, os códigos genéticos dos machos e das fềmeas. Teria que haver também um meio onde o usuário pudesse escolher os pares e simular acasalamentos, além de ter a opção de armazenar a seqüência desses acasalamentos para uma futura análise e comparação. Para solucionar o segundo problema, optou-se por utilizar técnicas de Inteligência Artificial (o que será tratado no próximo capítulo). Os dois sub-sistemas não estão interligados. A única ligação entre eles é a tela de Apresentação (figura.5.1) que procura dar ao usuário a impressão de estar trabalhando num sistema unificado.

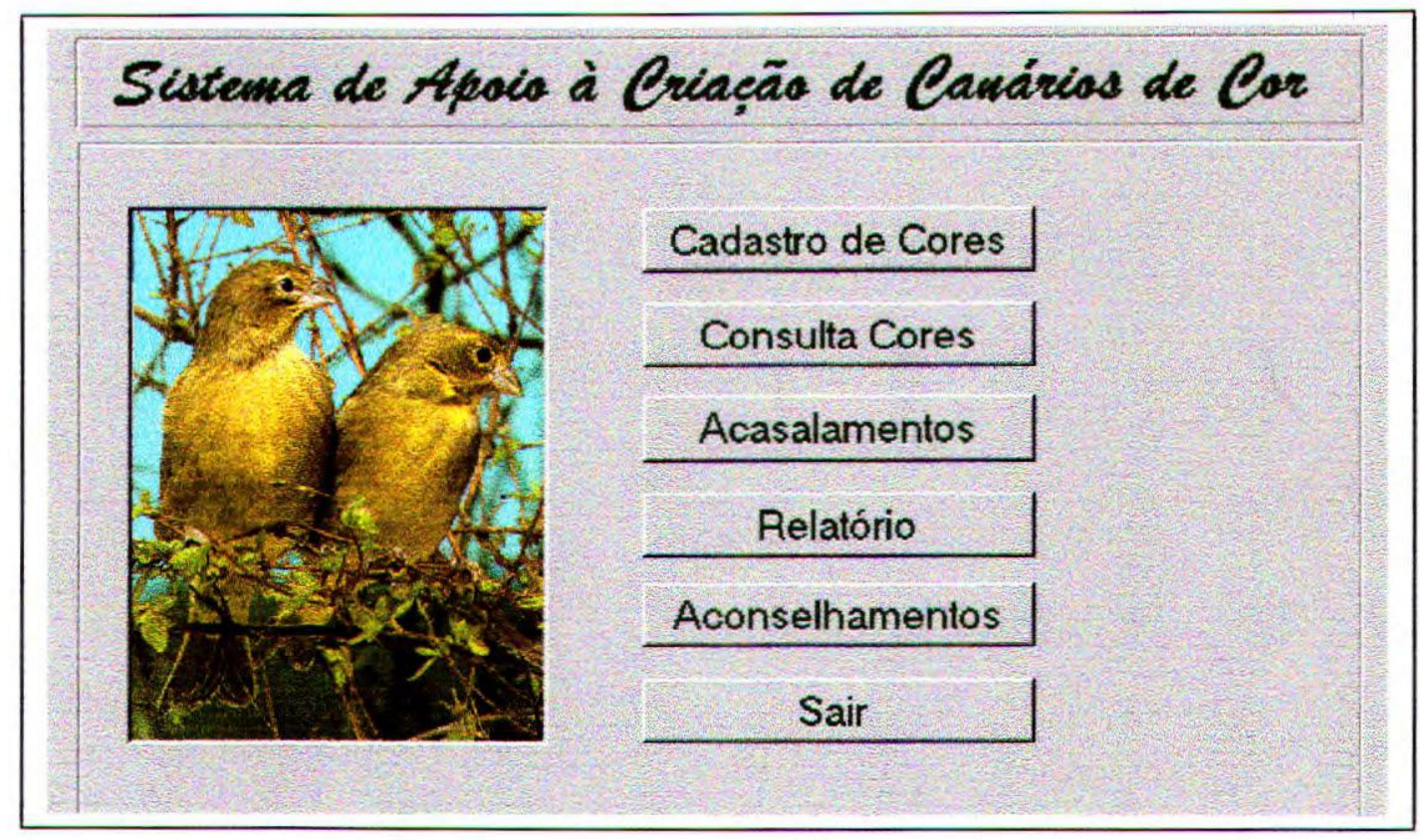

Figura 5.1 - Tela de Apresentação do sistema

\subsection{Especificação do Sub-sistema Acasalamentos}

Optou-se por desenvolver um banco de dados com as informações sobre acasalamentos. Um banco de dados contém duas espécies de informação: descrição de entidades e descrição de relacionamentos. As entidades são representadas por tabelas, que são estruturas fundamentais de um sistema de gerenciamento de um banco de dados relacional. Uma tabela é um objeto que armazena dados em registros (linhas) e campos (colunas). Os relacionamentos são associações que são estabelecidas entre campos comuns (colunas) entre duas tabelas. Um relacionamento pode ser do tipo um-para-um, um-para-muitos ou muitos-para-muitos. O banco de dados foi implementado utilizando a ferramenta Microsoft Access.

As seguintes tabelas foram criadas no sub-sistema Acasalamentos: Cadastro de Cores, Acasalamentos, Filhotes, Relação de Acasalamentos, Relação de Casais e Relação de Filhotes. A descrição dessas tabelas é apresentada no quadro 5.1. 


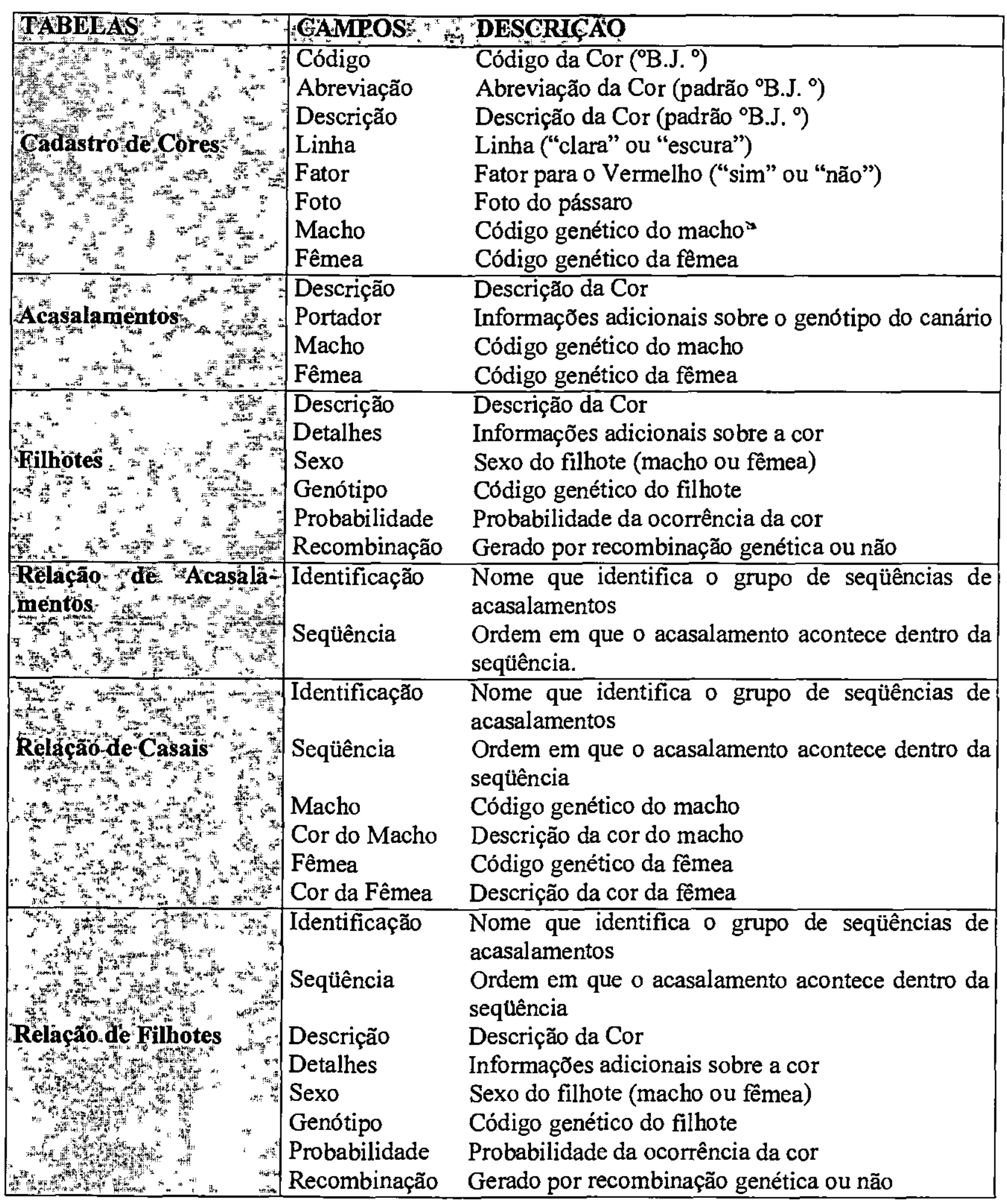

Quadro 5.1 - Descrição das tabelas do Sistema de Apoio à Criação de Canários de Cor.

As tabelas Acasalamentos e Filhotes são temporárias, ou seja, só armazenam dados durante a simulação e são inicializadas assim que o resultado do acasalamento é mostrado ao

\footnotetext{
" Nos campos "Código genético" são mantidas as fórmulas que representam o genótipo do canário para cada cor cadastrada. As fórmulas genéticas são tratadas no item 5.5 deste capitulo.
} 
usuário. Já as tabelas Relação de Acasalamentos, Relação de Casais e Relação de Filhotes mantêm registradas as seqüências de acasalamentos salvas pelo usuário. Nessas tabelas, o campo Identificação contém o nome que identifica a seqüência e o campo Seqüência é utilizado para manter a ordem em que os acasalamentos foram realizados. Essas três tabelas estão relacionadas como mostra a figura 5.2. A tabela "Relação de Casais" foi duplicada a fim de tornar a figura mais clara:

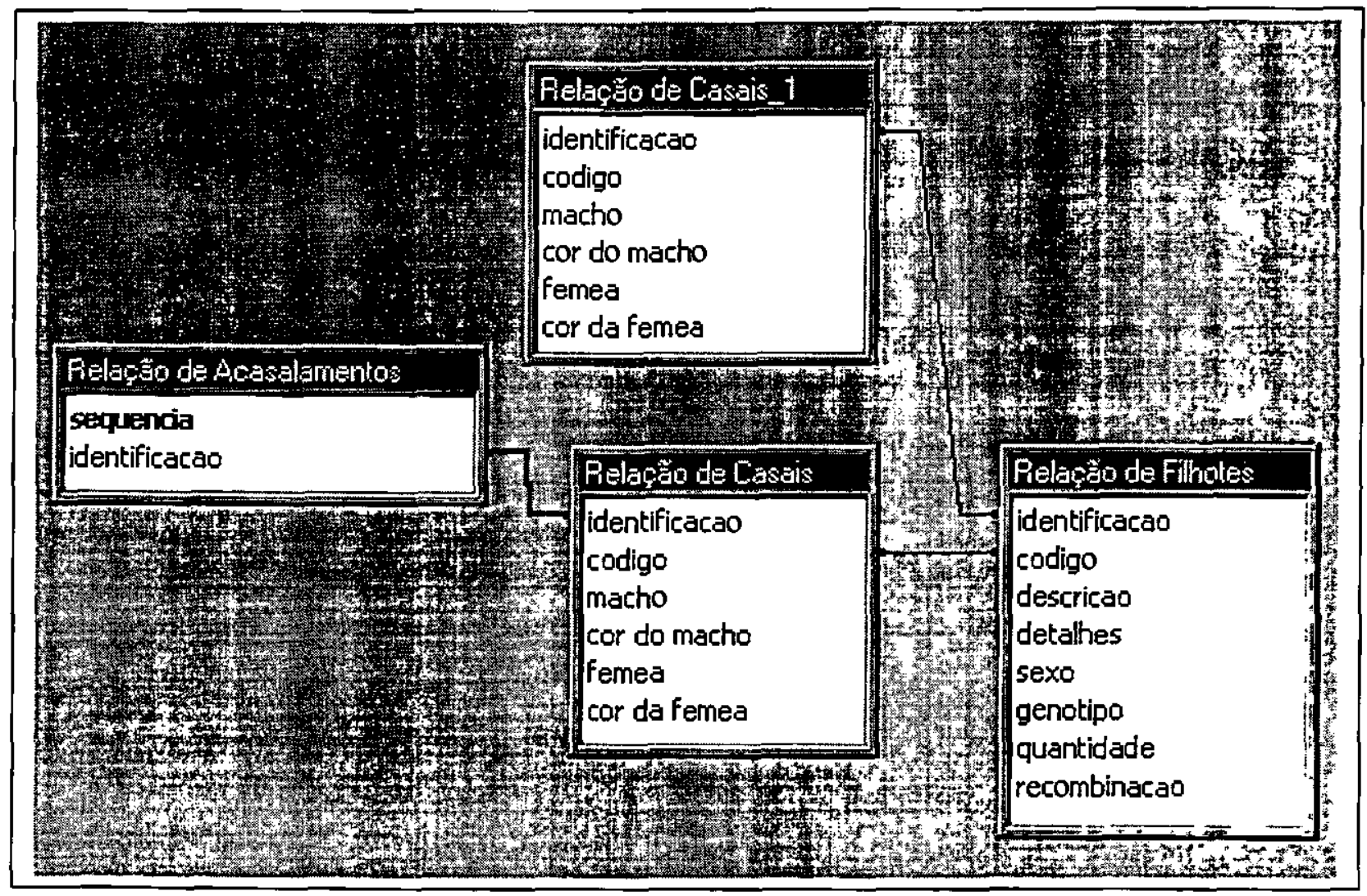

Figura 5.2 - Relacionamento entre as tabelas do sub-sistema Acasalamentos.

O tipo de relacionamento entre a tabela Relação de Acasalamentos - Relação de Casais e Relação de Casais - Relação de Filhotes é de um-para-muitos. Como pode ser visto na figura 5.3, há dois relacionamentos entre a tabela Relações de Casais e Relações de Filhotes, um para indicar os filhotes que pertencem a uma determinada seqüência de acasalamentos e outro para identificar quais filhotes foram gerados a partir do acasalamento de um determinado casal, dentro daquela seqüência.

Uma primeira visão do sub-sistema acasalamentos é apresentada no Diagrama de Fluxo de Dados (DFD) de nível 0 da figura 5.3. 


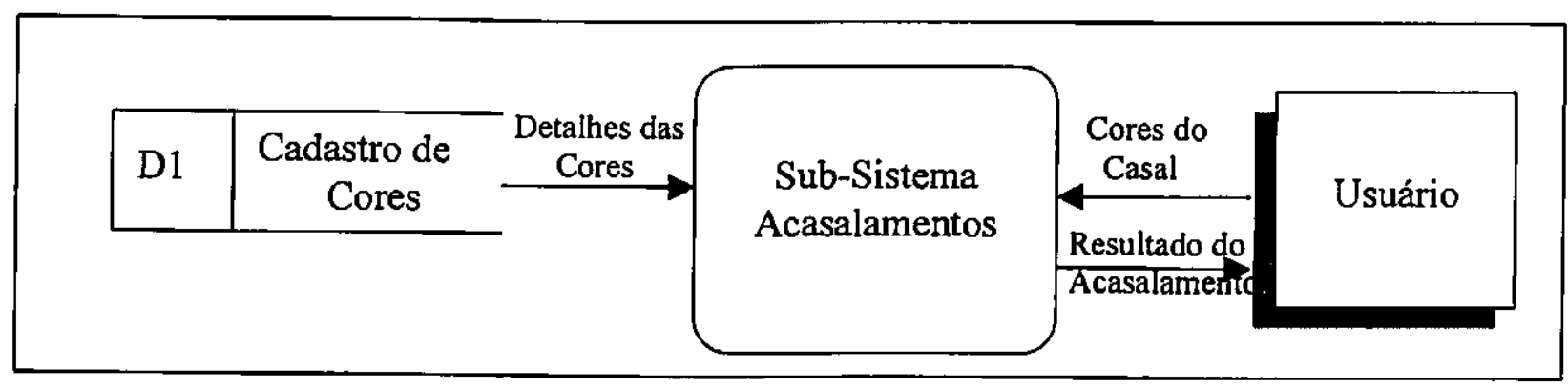

Figura 5.3 - DFD de nível 0

Conhecendo-se o domínio do sistema, passou-se para a especificação detalhada dos requisitos. Através de novas entrevistas, foram identificados os seguintes requisitos específicos:

- Um cadastro de cores para manter os dados que serão utilizados pelo sistema. O cadastro não deve ser visto como uma estrutura estática, tendo em vista que novas mutações podem ocorrer, gerando diferentes cores e consequientemente com diferentes códigos genéticos associados a elas.

- Uma tela que permita inclusões, alterações e exclusões no cadastro de cores.

- Uma tela onde o usuário possa escolher os casais para simular o acasalamento.

- Um processo para combinação genética, baseado na escolha dos casais e nos códigos genéticos cadastrados no Cadastro de Cores.

- Uma estrutura para manter as sequiências de acasalamentos para que possam ser consultadas pelo usuário posteriormente.

- Uma interface amigável e auto-explicativa.

Para entender a função, informação e comportamento do sistema foi desenvolvido um Diagrama de Fluxo de Dados mais detalhado. O DFD da figura 5.4 representa o sub-sistema de Acasalamentos do Sistema de Apoio à Criação de Canários de Cor. 


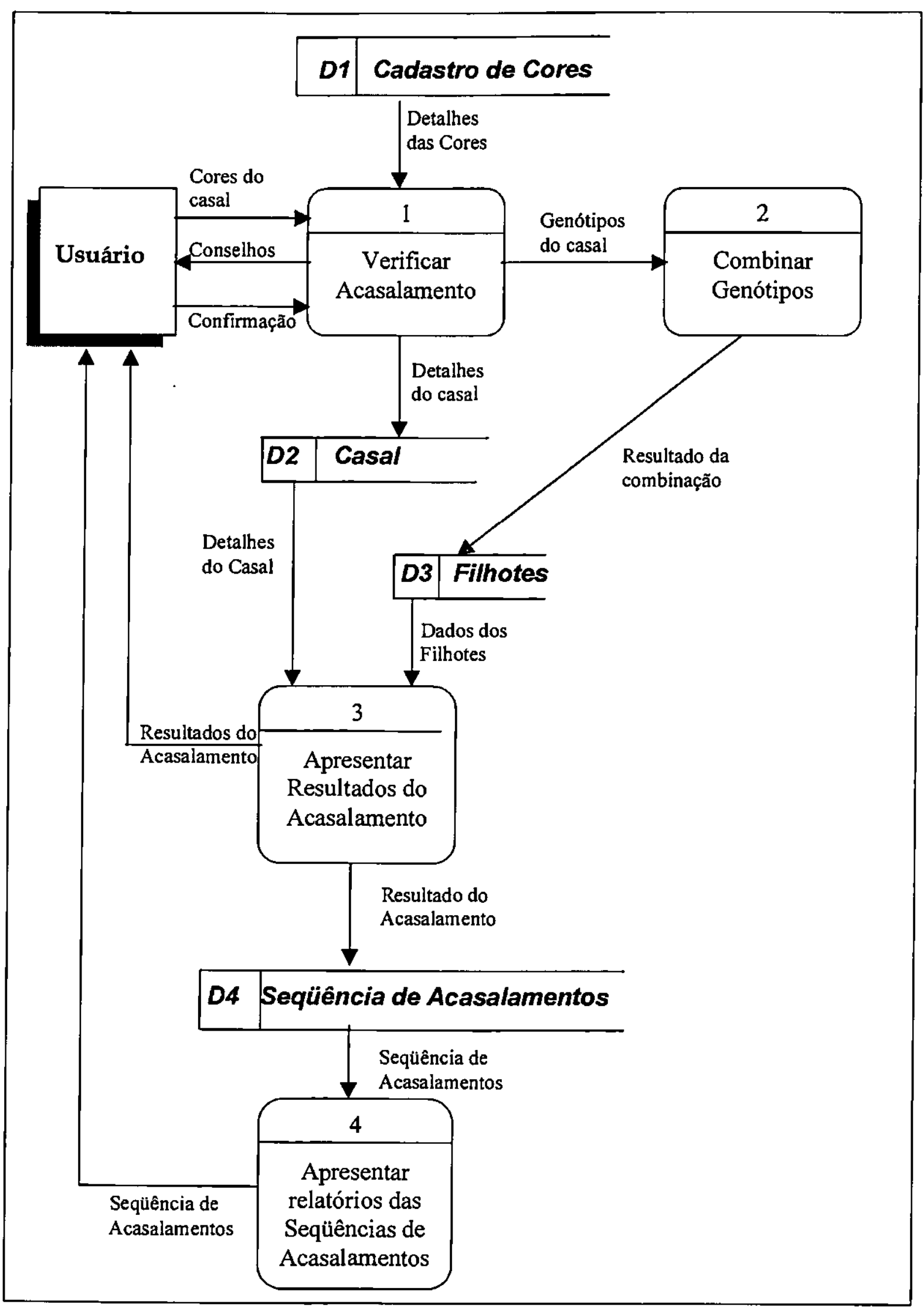

Figura 5.4 - Diagrama de Fluxo de Dados do "Sistema de Apoio à Criação de Canários de Cor" 


\subsection{Projeto e Implementação do Sub-sistema Acasalamentos}

O módulo de Acasalamentos se baseia principalmente na combinação genética dos pares de canários, onde podem ser realizadas simulações de seqüências de acasalamentos.

A primeira opção do Menu de Apresentação (figura 5.1) leva o usuário à tela de Cadastro de Cores (figura 5.5), cuja função é dar entrada às informações essenciais para o funcionamento dos outros módulos. Os campos "Código", "Descrição" e "Abreviação" seguem a nomenclatura oficial da Ordem Brasileira de Juizes de Ornitologia. O campo "Linha" contém a informação que identifica se a cor pertence à linha clara, representada pelas cores lipocrômicas (com ausência total de melanina), ou se a cor pertence à linha escura (cores melânicas). O campo "Fator para o Vermelho" indica se a cor cadastrada tem ou não o gene para o vermelho em seu código genético. Finalmente os campos "Macho" e "Fêmea" contêm as representações dos códigos genéticos que simbolizam cada um dos dezessete genes responsáveis pelas cores existentes. $\mathrm{O}$ cadastro foi preenchido com as 358 cores reconhecidas pela O.B.J.O., com as respectivas fotos. As informações são armazenadas em uma tabela e recuperadas sempre que o usuário solicitar um acasalamento, através da tela "Acasalamentos".

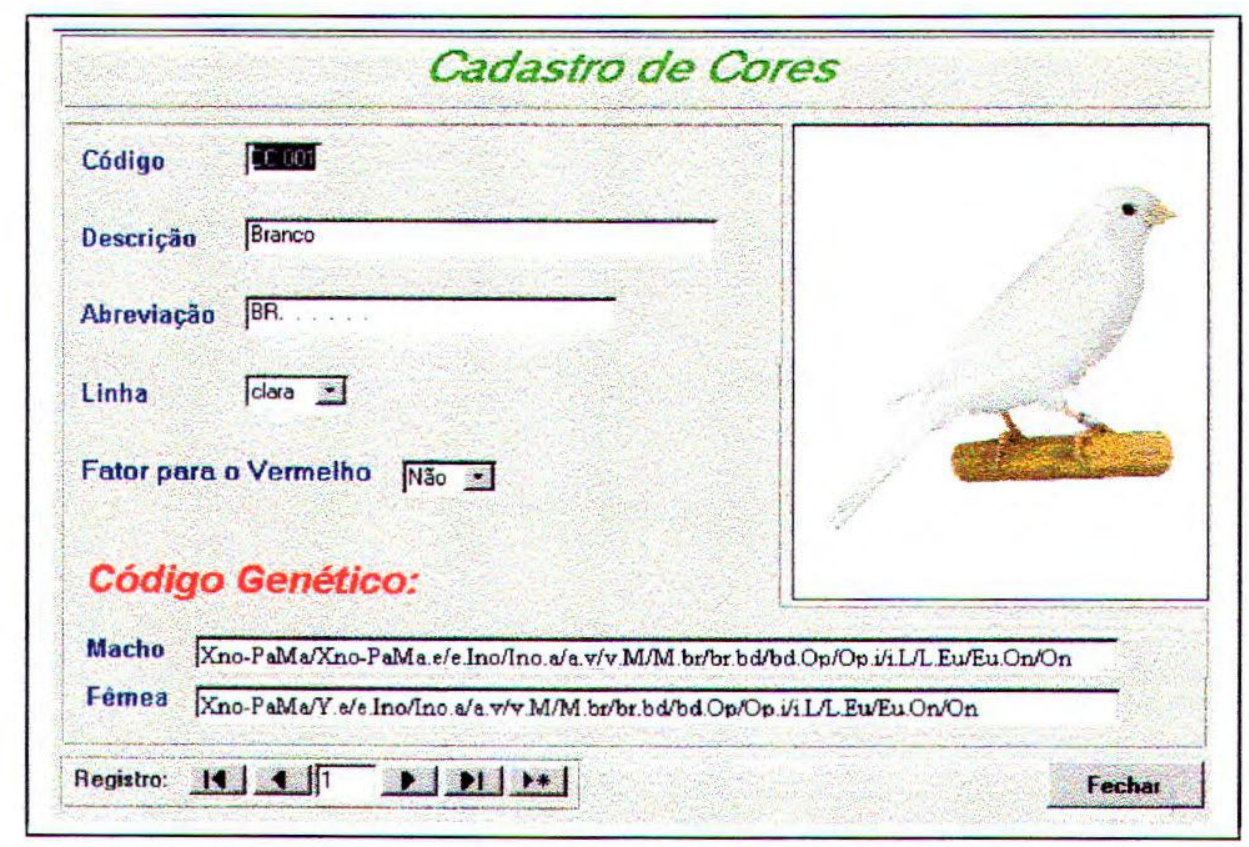

Figura 5.5 - Cadastro de Cores

O segundo botão do Menu de Apresentação (fig. 5.1) dá acesso à tela de Consulta Cadastro de Cores, exemplificada na figura 5.6, onde o usuário pode verificar o conteúdo do Cadastro de Cores através da seleção da cor desejada, sem opção de inclusão, alteração ou exclusão. 


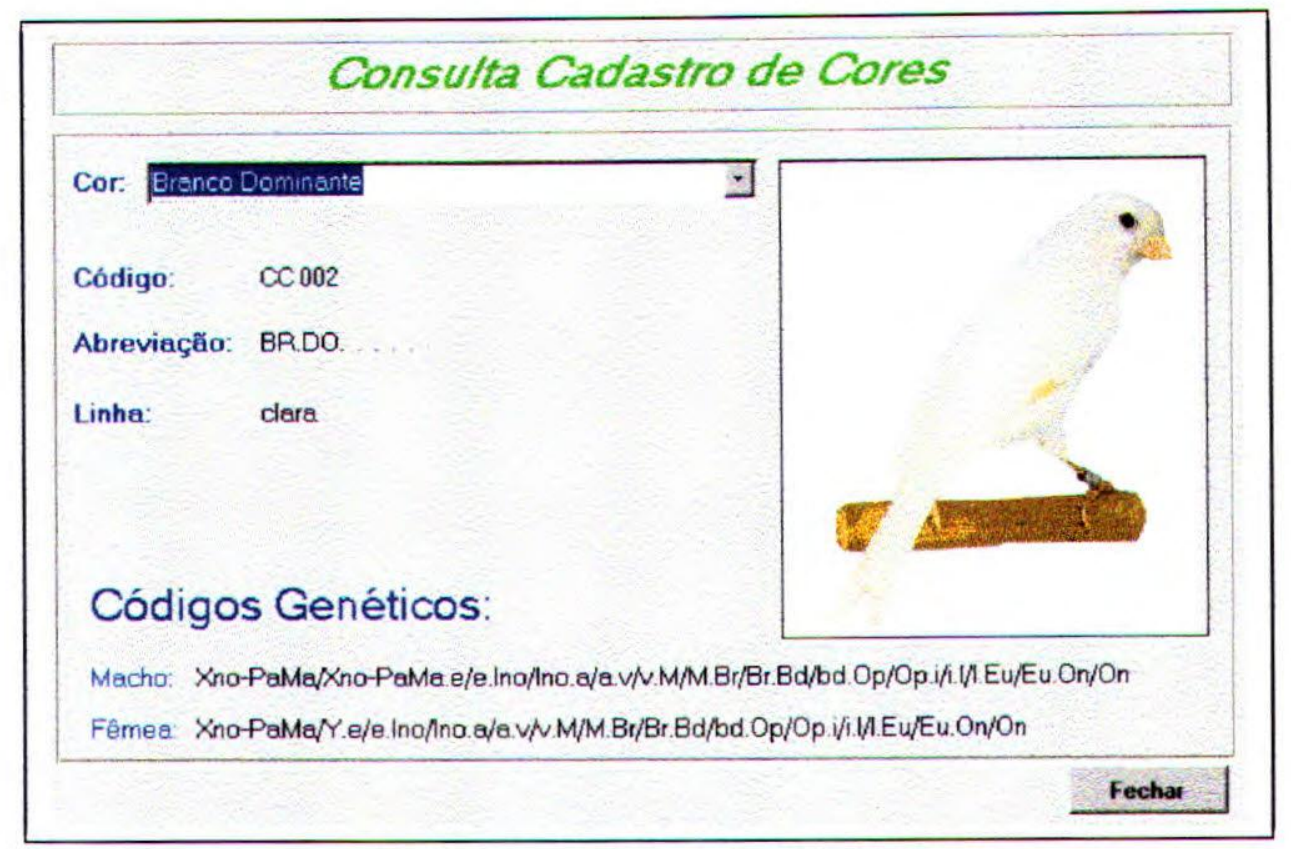

Figura 5.6 - Consulta ao Cadastro de Cores

A terceira opção do Menu de Apresentação abre a tela de Acasalamentos, exemplificada na figura 5.7. Nessa tela o usuário pode escolher as cores do canário macho e fềmea, a fim de verificar os fenótipos dos filhotes que podem ser obtidos através desse acasalamento. $\mathrm{O}$ código genético das cores escolhidas para o casal é recuperado do Cadastro de Cores e, através da indicação de quais genes os exemplares são portadores, os códigos genéticos são alterados pelo sistema.

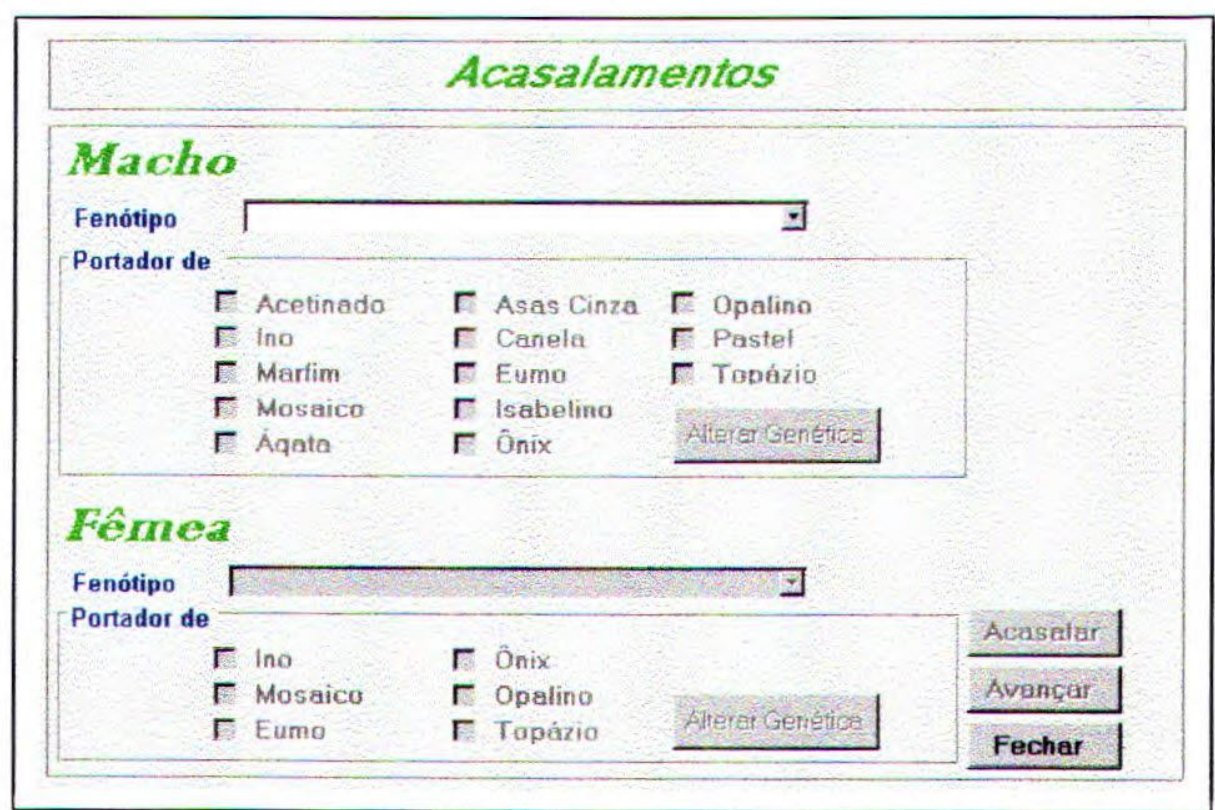

Figura 5.7 - Acasalamentos

Esse módulo permite ainda que o usuário incremente o código genético com informações adicionais, através da tela Alteração de Genótipos, exemplificada na figura 5.8. A maioria das 
informações desta tela só serão conhecidas pelo canaricultor se o mesmo tiver conhecimento dos antecedentes do pássaro, pois grande parte das características não são visíveis no fenótipo.

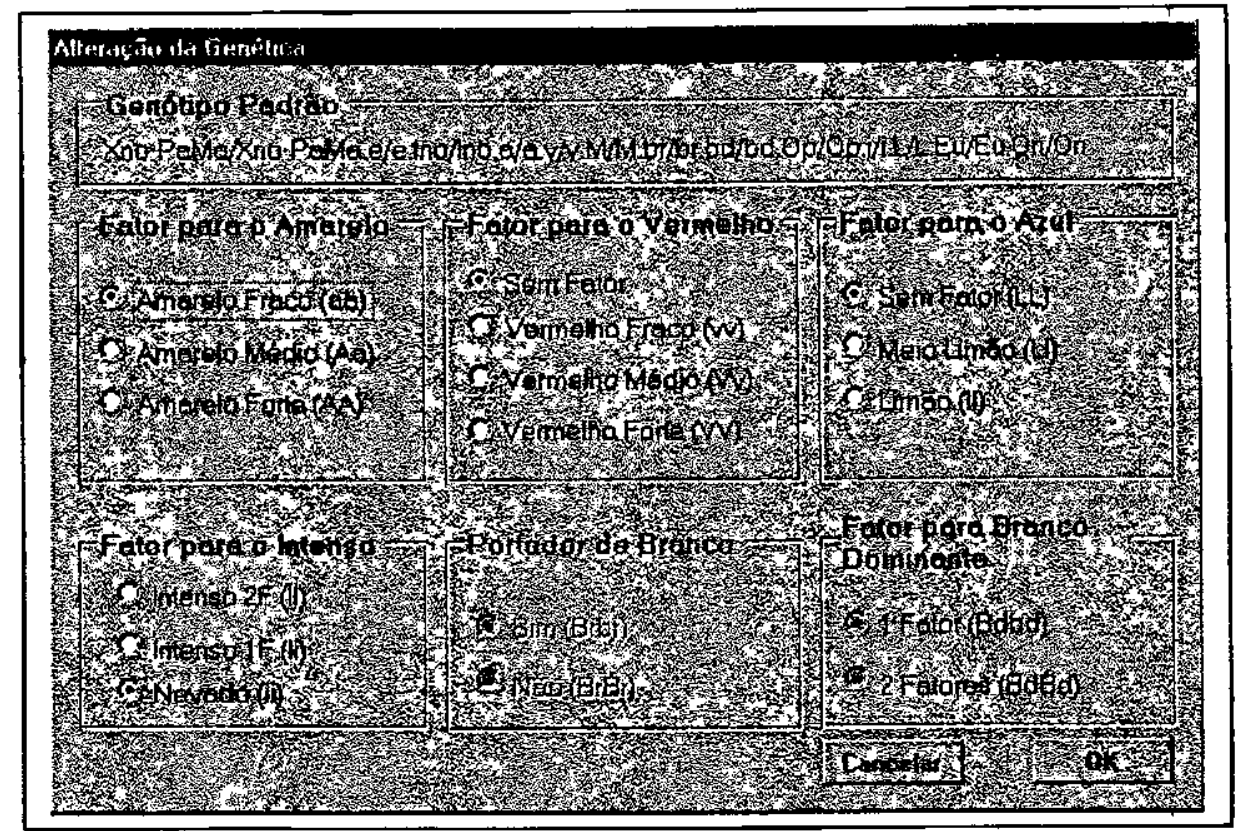

Figura 5.8 - Alteração de Genótipos através de informaçôes adicionais

Após a escolha das cores do casal e das informações adicionais, obtém-se o Resultado do Acasalamento (figura 5.9), que traz os nomes das cores e os códigos genéticos do macho e da fềmea, além de informações sobre a prole, com o percentual de probabilidade de ocorrência, 0 sexo, a descrição da cor e, opcionalmente, o genótipo de cada tipo de filhote gerado. A tela de Resultado do Acasalamento fornece ainda opções para salvar seqüências de acasalamentos para impressão de relatório ou voltar para a tela anterior, caso se queira fazer alguma modificação nas informações dadas anteriormente.

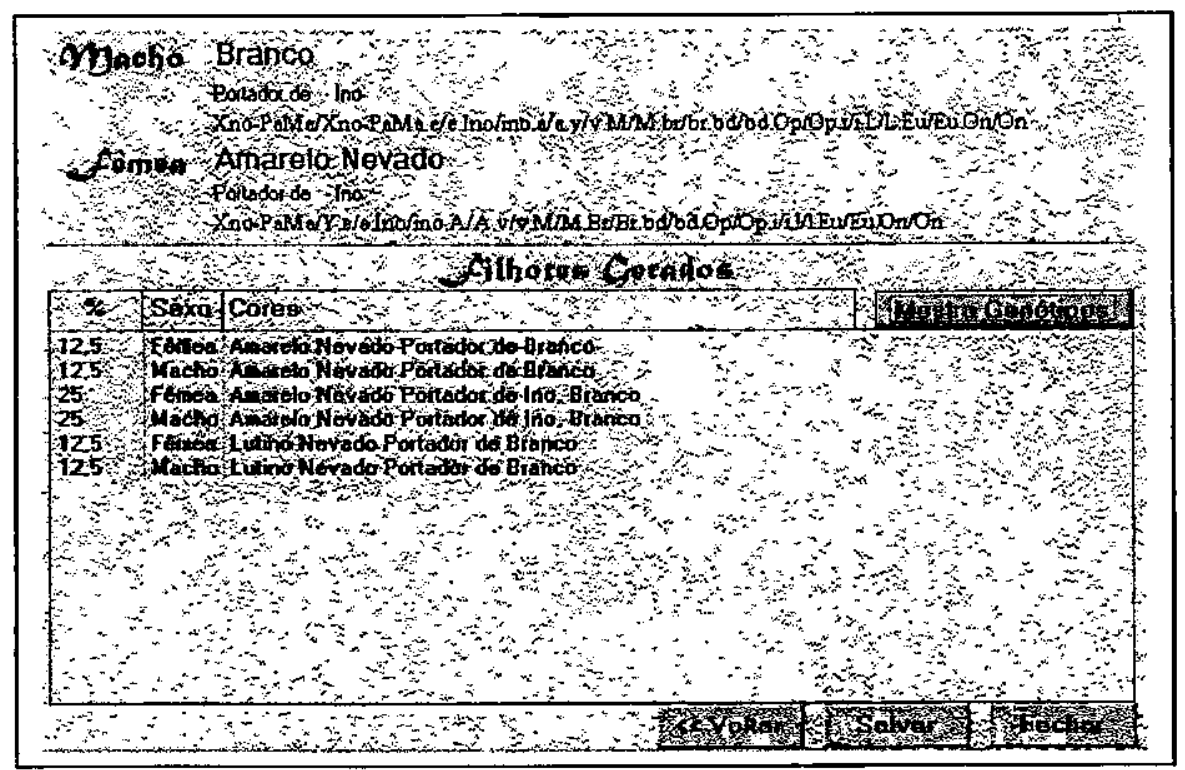

Figura 5.9 - Resultados do Acasalamento 
O quarto botão do Menu de Apresentação dá acesso ao relatório "Relação de Acasalamentos" que informa a seqüência de acasalamentos salvos pelo usuário, contendo a identificação dos casais e o resultado da prole.

O botão "Aconselhamentos" dispara a execução do módulo desenvolvido em LPA-Flex, cujo submenu apresenta as seguintes opções:

- "Encontrar o par ideal", cujo objetivo é informar qual ou quais as melhores opções para acasalamento, a partir das características do exemplar que o canaricultor possui.

- "Informações sobre o padrão O.B.J.O.", que procura orientar o usuário sobre as características ideais que um canário deve possuir a fim de se tornar competitivo em concursos.

\subsection{Fórmulas Genéticas}

Um dos pontos mais importantes do projeto foi a elaboração da fórmula genética de cada uma das 358 cores cadastradas no sistema. O código genético completo, ou seja, contendo todos os 17 genes para cores conhecidos até o momento, não consta nos livros, artigos e revistas que foram utilizados para a aquisição de conhecimento. Por causa disso, foi necessário montar cada um deles, seguindo a fórmula geral dos canários de cor, sugerida em [SIL87] e [SEI97]:

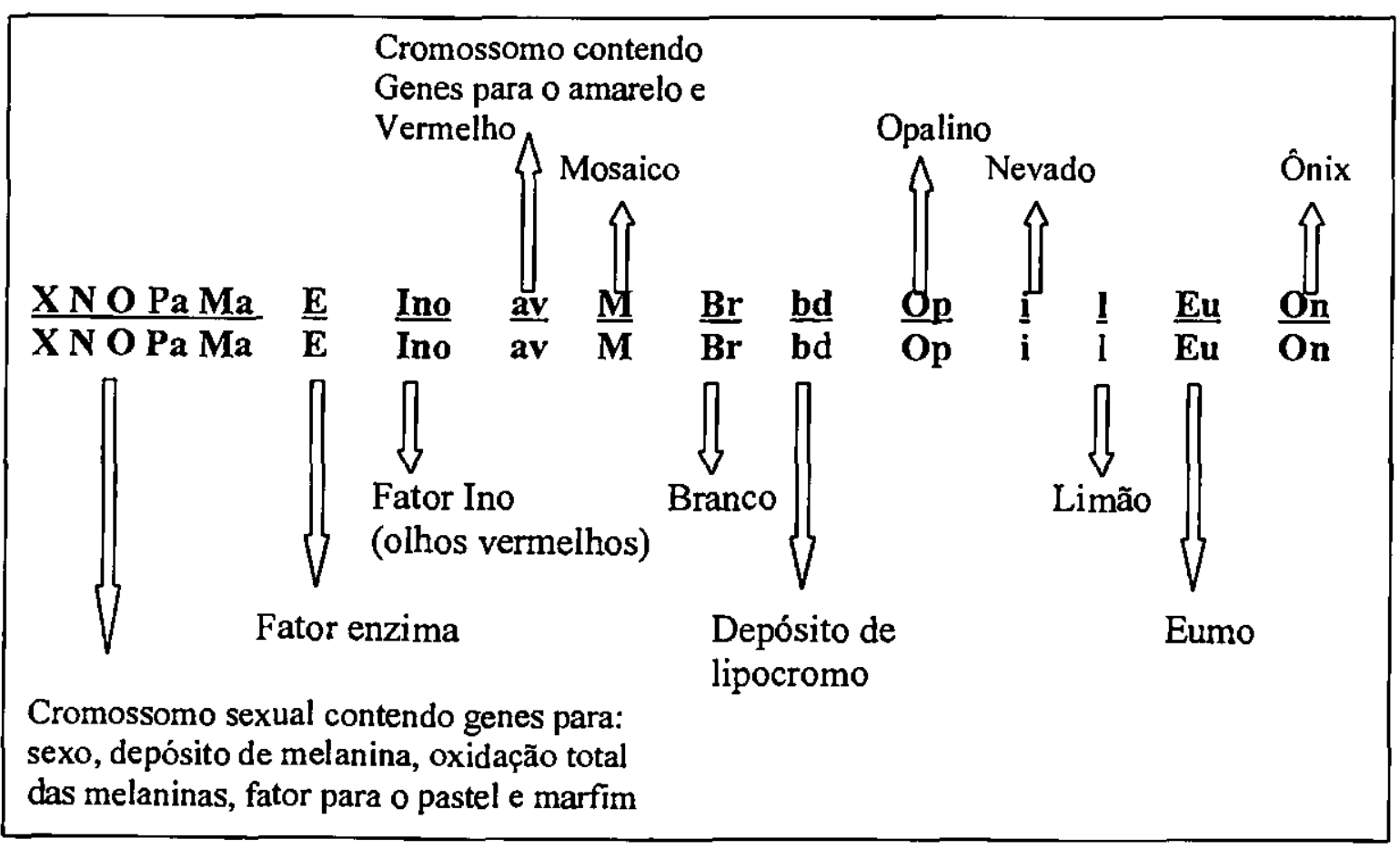

A fórmula acima representa um canário macho, sem qualquer gene mutante. A presença dos genes em mutação no código genético do pássaro e as combinações possiveis que podem ocorrer são responsáveis pela diversidade de cores encontradas nos canários atualmente. 
A combinação dos dezessete genes, dois a dois pode levar a um número bastante grande de códigos diferentes, o que poderia consumir algumas horas de processamento. Na prática isso não deve acontecer, pois o acasalamento entre exemplares de genótipos muito diferentes não é aconselhável e muito menos usual por parte dos criadores de canários. Um acasalamento entre pássaros com características tão distintas poderia gerar canários descaracterizados para concurso. Sempre quando se tenta fazer um acasalamento fora dos padrões, o sistema abre uma janela de avisos deixando a critério do usuário continuar ou não o processamento.

\subsection{Processo de Combinação de Genótipos}

A rotina responsável pelo fornecimento dos resultados dos acasalamentos foi desenvolvida em Borland $\mathrm{C}++5.01$. Essa rotina funciona da seguinte forma:

- recebe como parâmetro o genótipo do macho, que pode ser mais de um, caso haja possibilidade de ocorrer o crossing-over (a tela de Acasalamentos identifica essa possibilidade quando o cromossomo sexual do macho apresenta dois ou mais pares de genes alelos em heterozigoze e então pergunta ao usuário se ele deseja considerar também os resultados obtidos através da permutação desses genes).

- recebe também o genótipo da fêmea e a informação se o fator para o vermelho está contido ou não nos códigos genéticos. A presença do fator em somente um dos exemplares não é recomendada, gerando cores fora dos padrões.

- a partir dos parâmetros recebidos, a rotina passa a fazer as combinações possiveis, armazenando-as em estruturas de memória. Para tornar a rotina mais rápida, somente os genes que apresentam diferença entre o genótipo do macho e o da fêmea são combinados. Quando um gene para uma determinada característica for igual tanto no macho como na fêmea, ele simplesmente é transportado para o resultado. Esse cuidado foi necessário para economizar tempo de processamento.

- terminado o processo de combinação, a rotina passa a calcular as probabilidades de ocorrência de cada genótipo. Numa última etapa, através da análise dos códigos genéticos gerados, a rotina monta a descrição de cada cor e grava em um arquivo tipo texto, que será importado para uma tabela Acasalamentos e mostrado na tela Resultado de Acasalamentos, exemplificada na figura 5.9.

Parte do conhecimento adquirido, tanto através de livros e publicações em revistas especializadas, como de entrevistas com o especialista, foi utilizado na tela de Acasalamentos, a fim de "avisar" ao usuário que alguns acasalamentos não são recomendados, ou por gerar 
pássaros com fenótipos descaracterizados para concursos, ou por resultar em pássaros com problemas de plumagem. Esses avisos são mostrados em janelas, nas quais o usuário é obrigado a tomar uma decisão, informando ao sistema se o processo de acasalamento deve ou não ser efetivado. Essa confirmação é necessária quando o usuário tenta acasalar, por exemplo:

1. Exemplares da linha clara com exemplares da linha escura

2. Um exemplar que possua fator para o vermelho em seu genótipo com outro que não o possua

3. Nevados entre si

4. Canários mosaicos com não mosaicos

5. Canários pertencentes às cores escuras, quando ambos não possuam genes mutantes para a mesma característica, como por exemplo, exemplar topázio com um não topázio.

\subsection{Considerações Finais}

Apesar do sistema desenvolvido possuir poucas entidades e relacionamentos, sua implementação foi bastante complexa e muitos testes foram necessários até se chegar à versão final. Um cuidado especial foi dispensado ao se projetar a interface do sistema com o usuário. Uma análise global do perfil do usuário a que esse software se destina revelou que a grande maioria não tem grandes contatos com computadores. Os criadores de canários são profissionais de diversas áreas diferentes, que normalmente possuem um tempo limitado para se dedicar a essa atividade. Grande parte desse tempo dispensado aos canários é utilizada para a manutenção do plantel, como limpeza do local, higiene, medicação e alimentação dos pássaros, entre outras coisas. Por isso o sistema procura apresentar uma interface fácil de aprender, simples de usar, direta e amigável, com o mínimo de digitação possível e com tempo de resposta rápido o suficiente para não gerar frustração e desânimo por parte do usuário.

Com exceção do Cadastro de Cores, que já está preenchido com todas as cores de canários existentes atualmente, o restante do sistema não exige nenhum tipo de digitação. $O$ diálogo entre o usuário e o software é feito através de botões de comando acionados por um mouse, sendo que tais botões vêm sempre acompanhados de uma caixa de texto explicativa que aparece toda vez que o ponteiro do mouse é colocado sobre eles.

Uma outra facilidade que o sistema apresenta é a foto associada a cada uma das cores cadastradas. A imagem do pássaro dentro do cadastro é bastante útil devido à grande variedade de cores e está disponível para ser utilizada em outros tipos de consulta que poderão ser implementadas no futuro. 
Aconselhamentos

\subsection{Introdução}

O principal objetivo do módulo de Aconselhamentos é armazenar o conhecimento de especialistas em criação de canários de cor e poder responder numa linguagem clara e simples às dúvidas que um usuário pode ter durante a escolha dos melhores casais para acasalamento. Para atender a esses objetivos, algumas técnicas de Inteligência Artificial são utilizadas. O sistema criado procura automatizar algumas funções normalmente realizadas pelos criadores de canários, economizando trabalho intelectual e liberando o usuário de trabalhos dificeis, que consomem tempo e são passiveis de erros.

Assim como outros sistemas baseados em conhecimento, esse sistema contém um conjunto de regras que se transformam em fatos conforme o usuário vai respondendo às perguntas que lhe são colocadas pelo programa. As perguntas se referem ao exemplar que o usuário possui e deseja utilizar no acasalamento. Através das respostas obtidas, o programa consegue chegar a uma solução e apresentá-la ao usuário. Tal solução é composta de todas as caracteristicas que um canário deve possuir para que, ao ser acasalado com o exemplar apresentado pelo usuário, se obtenham filhotes dentro de um padrão ideal. Cada característica sugerida possui uma justificativa, que é apresentada ao usuário sempre que ele requisitar.

\subsection{Fases do Desenvolvimento}

\subsubsection{Identificação do Domínio}

Muitas pessoas começam uma criação de canários de cor sem ter noção alguma sobre genética ou sobre as implicações que pode ter um acasalamento de pássaros, cujas características são tão distintas ou mesmo tão semelhantes que podem levar a filhotes com cores ruins, com defeitos físicos e até a morte de alguns.

Um criador inexperiente poderia achar que o acasalamento entre pássaros de mesmo fenótipo teria sucesso em cem porcento dos casos, o que não é verdade. Um exemplo disso seria o acasalamento entre Nevados, pássaros que normalmente possuem penas mais longas que os Intensos, cujo acasalamento consecutivo acaba levando a filhotes com plumagem abundante, que prejudica a forma e favorece o aparecimento de quistos. 
Devido à grande quantidade de conhecimento necessário para se ter sucesso nesse tipo de atividade, alguns canaricultores experientes preferem se especializar em um pequeno grupo de cores, muitas vezes se limitando à criação de canários da linha clara, mosaicos, ou até mesmo apenas canários brancos. $O$ fato de um canaricultor optar por brancos em seu canaril não quer dizer que ele não precise ter canários de cores diferentes. Existem várias outras características importantes que devem ser levadas em consideração e, às vezes, é necessário acasalar brancos com não brancos para se chegar a uma plumagem perfeita, ou para se obter canários com formas mais elegantes.

\subsubsection{Aquisição de Conhecimento}

Uma vez identificado o domínio do problema, iniciou-se a fase de aquisição de conhecimento, que se estendeu até o final do projeto. A extração do conhecimento necessário ao desenvolvimento do sistema foi feita através de pesquisas em livros e revistas especializadas sobre a criação de canários de cor. Também foram feitas entrevistas com um especialista da área, que validou o conhecimento obtido durante a pesquisa, acrescentando informações importantes que viriam enriquecer ainda mais a base de conhecimento. Uma das entrevistas mais interessantes e esclarecedoras durante essa fase foi realizada no próprio plantel de canários.

\subsubsection{Implementação do Módulo de Aconselhamentos}

O conhecimento obtido através das pesquisas e entrevistas era bastante diversificado, isto é, havia informações sobre o acasalamento de canários das mais diversas cores, além de informações que se aplicam aos canários de um modo geral, como a forma do bico, o comprimento das penas, etc. Foi necessário, então, agrupar o conhecimento de acordo com as informações que continham, a fim de facilitar sua representação dentro da Base de Conhecimento.

Regras de Produção foram utilizadas para representar o conhecimento nesse sistema. Uma regra de produção consiste de pares "condição $\rightarrow$ ação ou conclusão". Por exemplo:

Se um canário possui a plumagem opaca

\section{Então acasale com um exemplar que possua plumagem brilhante.}

Sempre que uma regra de produção é disparada, ou seja, tenha sua condição satisfeita, a ação ou conclusão associada a essa condição é utilizada.

Para implementar o módulo de Aconselhamentos, foi utilizada uma shell, o LPA-Flex', um pacote de aplicativos projetado para construção de sistemas especialistas, que dá suporte à 
programação baseada em regras de produção e possui uma linguagem própria, a Knowledge Specification Language (KSL), baseada na língua inglesa, que torna o programa legível, fácil de ser entendido até mesmo por não programadores.

\section{Base de Conhecimento}

A Base de Conhecimento é a parte do sistema que armazena os fatos, regras e conceitos sobre o domínio de conhecimento. No módulo de Aconselhamentos, a Base de Conhecimento é composta por um grupo de dezesseis perguntas relacionadas ao canário que o usuário possui $\mathrm{e}$ deseja acasalar. Nem sempre todas as perguntas serão apresentadas ao usuário pois algumas dependem das respostas de questões anteriores. As perguntas podem ser justificadas toda vez que o usuário desejar saber o porquê de cada uma delas. Tais justificativas são importantes para o usuário entender a linha de raciocínio do sistema e são facilmente implementadas com o uso do LPA-Flex. A Base de Conhecimento possui também sessenta e sete regras que são disparadas somente quando todas as suas condições são satisfeitas. A interação do usuário com a Base de Conhecimento se dá através de janelas de diálogo.

A primeira janela apresentada ao usuário no módulo de Aconselhamentos é um menu de opções, no qual ele pode escolher uma das alternativas:

$>$ Encontrar o par ideal

$>$ Informações sobre padrões O.B.J.O.

$>$ Voltar ao menu principal

A opção "Informações sobre padrões O.B.J.O." descreve as características que um canário deve possuir para conseguir pontuação máxima em concursos, segundo os padrões da Ordem Brasileira de Juizes de Ornitologia. O usuário pode utilizar essas informações para selecionar um exemplar dentre os seus que se aproxime o máximo possível do padrão ideal. A opção "Voltar ao menu principal" faz com que o sistema retorne à tela de Menu de Apresentação descrita no capítulo anterior. Finalmente, "Encontrar o par ideal" dispara uma seqüência de perguntas sobre o exemplar que o usuário deseja utilizar no acasalamento, com o objetivo de encontrar o parceiro com características ideais para se conseguir filhotes próximos ao padrão aceito pela O.B.J.O. Em alguns casos, as justificativas das perguntas feitas também fornecem algumas dicas e esclarecimentos a fim de auxiliar o usuário na sua resposta. As perguntas e opções são esquematizadas nas figuras 6.1.(a) e 6.1 (b) Nesse esquema, algumas perguntas foram duplicadas somente para tornar a figura mais clara.

\footnotetext{
* Logic Programming Associates (LPA) é uma software house inglesa especializada no desenvolvimento e suporte à compiladores Prolog e softwares relacionados.
} 

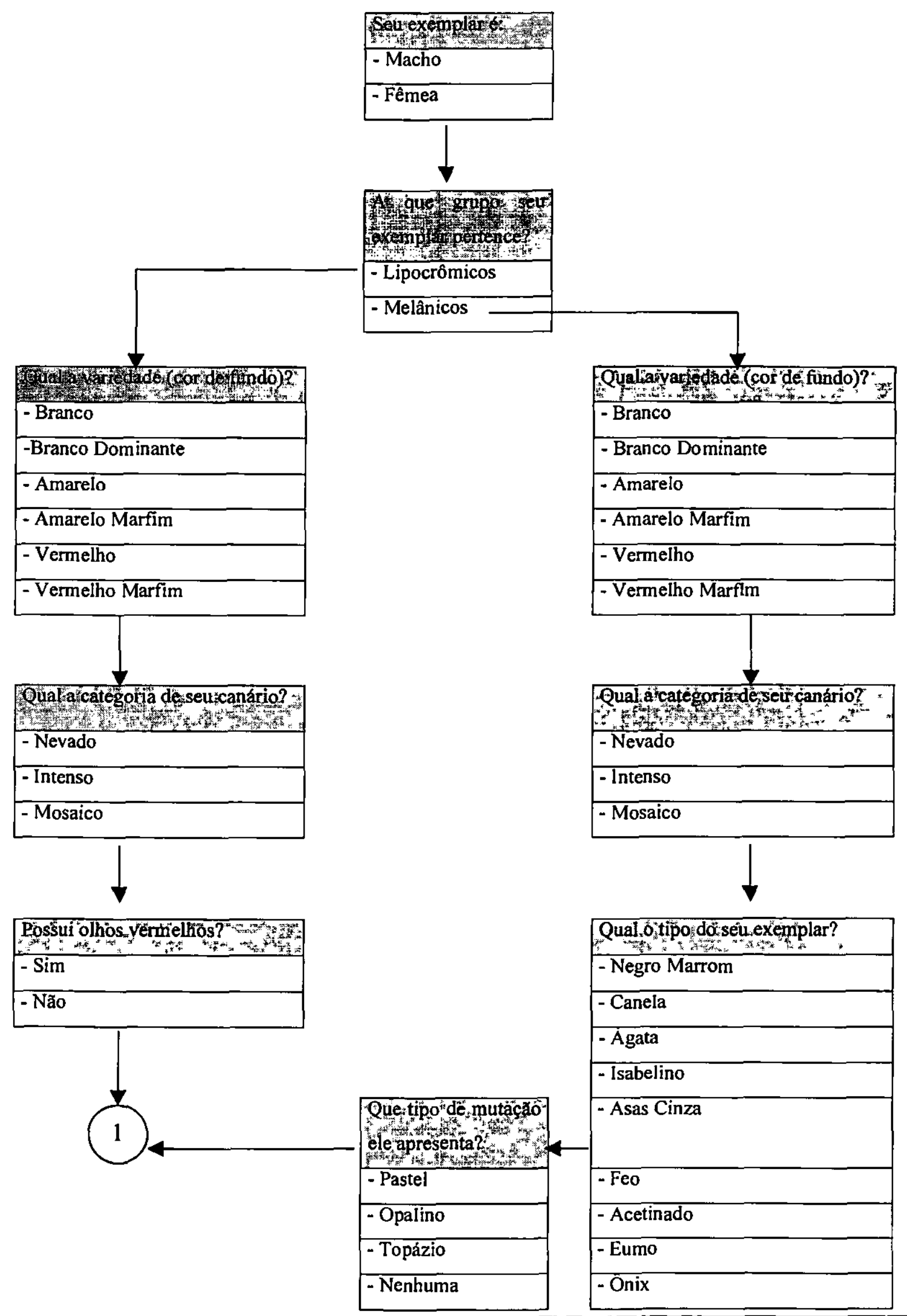

Figura 6.1(a) - Esquema de perguntas do módulo de Aconselhamentos 


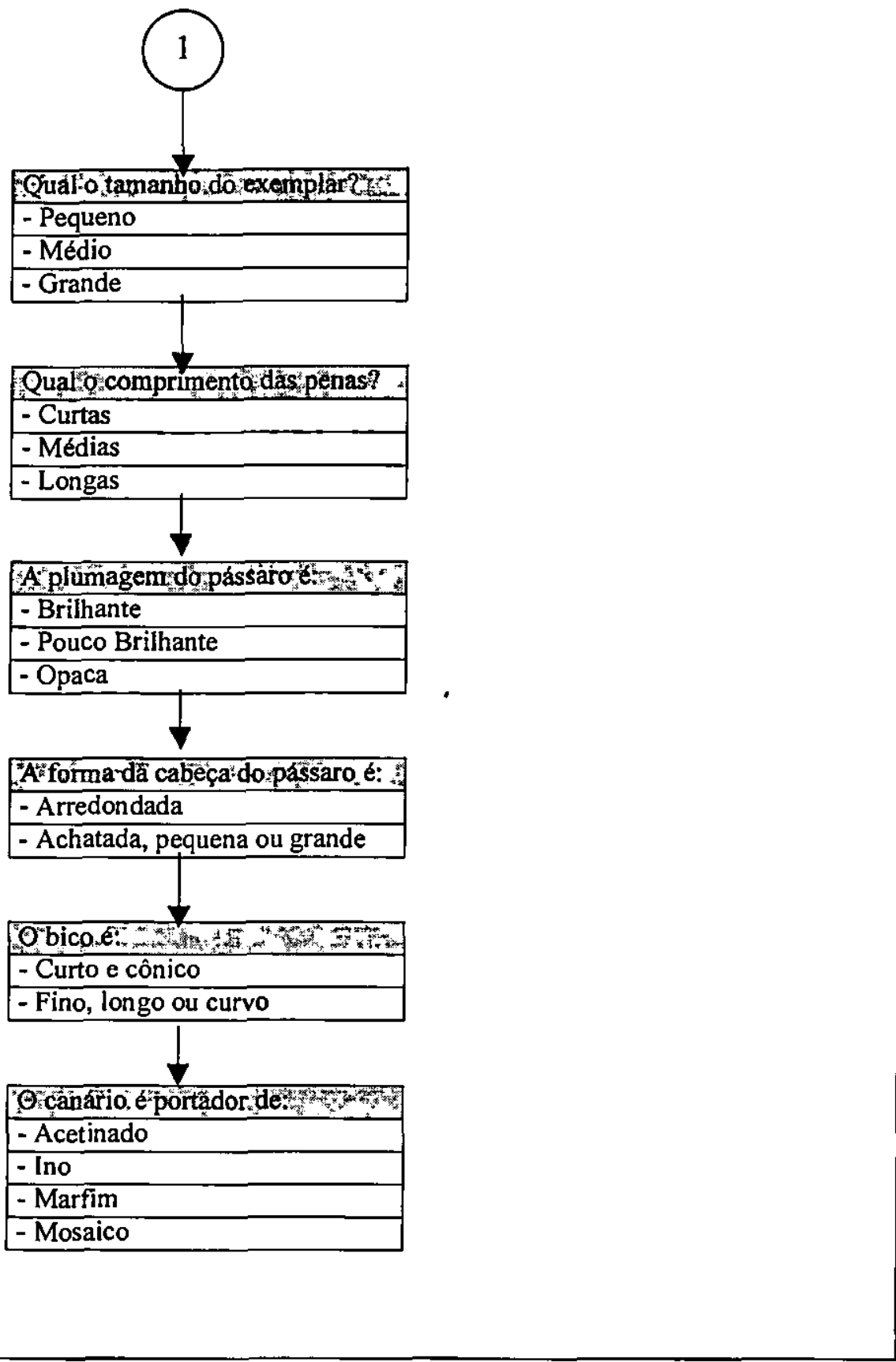

Figura 6.I (b) - Esquema de perguntas do módulo de Aconselhamentos (continuação) 
Um conjunto das principais regras relacionadas aos canários lipocrômicos é descrito nas figuras 6.2 (a) e 6.2 (b). Essas regras, juntamente com as regras referentes às características físicas do pássaro (tamanho, estrutura das penas, forma da cabeça e bico, etc.) e o conjunto de regras referentes aos canários melânicos compõem a base de conhecimento do módulo de Aconselhamentos. Conforme as regras vão sendo disparadas, o texto final que será apresentado ao usuário vai sendo montado com as conclusões de cada uma.

Se: o canário é um lipocrômico, e não possui olhos vermelhos, $\mathrm{e}$ possui cor de fundo Amarela, e pertence à categoria Nevado

Então: acasale com um Amarelo Intenso, Amarelo Marfim Intenso, Branco Dominante, Branco, Lutino Intenso, Lutino Marfim Intenso, Albino ou Albino Dominante.

Se: o canário é um lipocrômico, e não possui olhos vermelhos, $\mathrm{e}$ possui cor de fundo Amarela, e pertence à categoria Intenso

Então: acasale com um Amarelo Nevado, com névoa curta. Também pode-se utilizar um Amarelo Intenso, desde que apresente schimel

Se: o canário é macho, e

é lipocrômico, e não possui olhos vermelhos, $\mathrm{e}$ possui cor de fundo Amarelo Marfim

Então: acasale com um Amarelo ou Amarelo Marfim

Se: o canário é fềmea, $\mathrm{e}$ é lipocrômico, e não possui olhos vermelhos, $\mathrm{e}$ possui cor de fundo Amarelo Marfim

Então: acasale com um Amarelo, Amarelo Marfim ou portador de Marfim

Se: o canário é lipocrômico, e não possui olhos vermelhos, $\mathrm{e}$ possui cor de fundo Amarelo, e pertence à categoria Mosaico

Então: acasale com um Amarelo Mosaico ou Branco Dominante

Figura 6.2 (a) - Algumas regras que compõem a Base de Conhecimento do módulo de Aconselhamentos 
Se: o canário é lipocrômico, e

não possui olhos vermelhos, $\mathrm{e}$

possui cor de fundo Vermelha, e

pertence à categoria Nevado

Então: acasale com um Vermelho Intenso, Vermelho Marfim Intenso, Rubino Intenso ou Rubino Marfim Intenso

Se: o canário é macho, $\mathrm{e}$

é lipocrômico, e

não possui olhos vermelhos, $\mathrm{e}$

possui cor de fundo Vermelho Marfim

Então: acasale com um Vermelho Intenso, Vermelho Marfim ou portador de Marfim

Se: o canário é lipocrômico, e

não possui olhos vermelhos, $\mathrm{e}$

possui cor de fundo Vermelha, e

pertence à categoria Mosaico

Então: acasale com um Vermelho Mosaico

Se: o canário é lipocrômico, e

não possui olhos vermelhos, $\mathrm{e}$

possui cor de fundo Vermelha, e

pertence à categoria Branco Dominante

Então: acasale de preferência com um Amarelo Nevado. Procure nunca acasalar com Amarelo Intenso. Acasale com outro Branco Dominante somente senão houver outra alternativa

Se: o canário é lipocrômico, e

não possui olhos vermelhos, $\mathrm{e}$

possui cor de fundo Branco

Então: acasale com um pássaro Branco, Branco Dominante, Mosaico ou Amarelo

Nevado (sendo os três últimos portadores de recessivo)

Se: o canário é lipocrômico, e

possui olhos vermelhos

Então: acasale como satinê, e não como ino, a não ser que seu canário seja Autêntico

Se: o canário é lipocrômico, e não possui olhos vermelhos, $\mathrm{e}$ possui cor de fundo Vermelha, e pertence à categoria Intenso

Então: acasale com um Vermelho Nevado, com névoa curta. Também pode-se utilizar um Vermelho Intenso, desde que apresente schimel.

Figura 6.2 (b) - Algumas regras que compõem a Base de Conhecimento do módulo de Aconselhamentos (continuação) 


\section{Motor de Inferência}

O motor de Inferência é utilizado para descrever a parte do programa que interpreta as regras de um Sistema Baseado em Conhecimento. É o motor de inferência que decide que fatos e regras devem ser utilizados de acordo com as respostas do usuário às perguntas feitas pelo programa.

O método mais simples para selecionar a regra a ser disparada é "primeiro a chegar, primeiro a ser servido", first come first served (fcfs), que interrompe a verificação das regras assim que encontra a primeira que tenha todas as condições satisfeitas. Esse método não é apropriado ao sistema em questão pois, no módulo de Aconselhamentos, mais de uma regra pode ser disparada, uma vez que várias características do canário estão sendo avaliadas ao mesmo tempo. Por causa disso, foi utilizado um esquema de Resolução por Conflito, conflit-resolution scoring scheme (crss0), normalmente utilizado quando se quer decidir dentre várias regras disparadas. $\mathrm{O}$ conflito existente é resolvido escolhendo-se a regra de mais alta prioridade. No programa desenvolvido, esse comando é utilizado com o parâmetro 0 , que considera todas as regras e só pára quando um critério de término for satisfeito.

O método de raciocínio utilizado pelo Motor de Inferência nesse sistema foi o Forward Chaining. Nesse método o sistema parte dos fatos informados e, com base nas regras existentes, consegue chegar a uma conclusão e apresentá-la ao usuário. O Motor de Inferência conta também com uma agenda, cuja função é determinar as regras correntes disponíveis. Assim, toda vez que o programa é iniciado, todas as regras existentes ou apenas um subconjunto delas podem fazer parte dessa agenda e, após a seleção e disparo de uma regra, a agenda pode ser atualizada e revisada pelo Motor de Inferência, que a utiliza como base para o próximo ciclo de perguntas. Há vários algoritmos de atualização da agenda como: remover a regra disparada do conjunto de regras da agenda (once), mover essa regra para o início ou final da agenda (front/back), etc ${ }^{\rtimes}$. Na implementação do módulo de Aconselhamentos, a agenda contém inicialmente todas as regras e a atualização é feita através do algoritmo cycle. Nesse algoritmo a agenda é vista como uma fila circular: ao final de cada ciclo do Motor de Inferência, ou seja, após o sistema dar as respostas ao usuário, as regras são mantidas e as perguntas são apresentadas sempre na mesma ordem.

Uma das características de um Sistema Baseado em Conhecimento é a capacidade que ele tem de explicar ao usuário o raciocínio que foi utilizado para se chegar à solução proposta. $O$ LPA-Flex disponibiliza uma lista contendo os nomes das regras que foram realmente disparadas durante a sessão de forward chaining e as mostra automaticamente através de uma janela após a

Os algoritmos para atualização da agenda podem ser vistos em [PUG97]. 
apresentação da solução do problema ao usuário. Na prática, a janela contém os nomes de todas as regras que foram satisfeitas durante o ciclo de perguntas e respostas e por causa disso deve-se tomar um cuidado especial, dando nomes significativos às regras que compõem a Base de Conhecimento. O exemplo das figuras 6.3 (a) e 6.3 (b) mostra uma seqüência de janelas que fazem parte do módulo de Aconselhamentos. No quadro (a), o usuário responde à pergunta do programa sobre o formato e tamanho do bico do canário que ele pretende utilizar no acasalamento. Após encerrar a sessão de perguntas, o programa sugere que o canário seja acasalado com um exemplar que possua bico de características contrárias ao do exemplar em questão (b). A janela apresentada no quadro (c) disponibiliza as explicações ao usuário que, através da seleção daquela que lhe interessa, obtém a justificativa para a resposta dada (d).

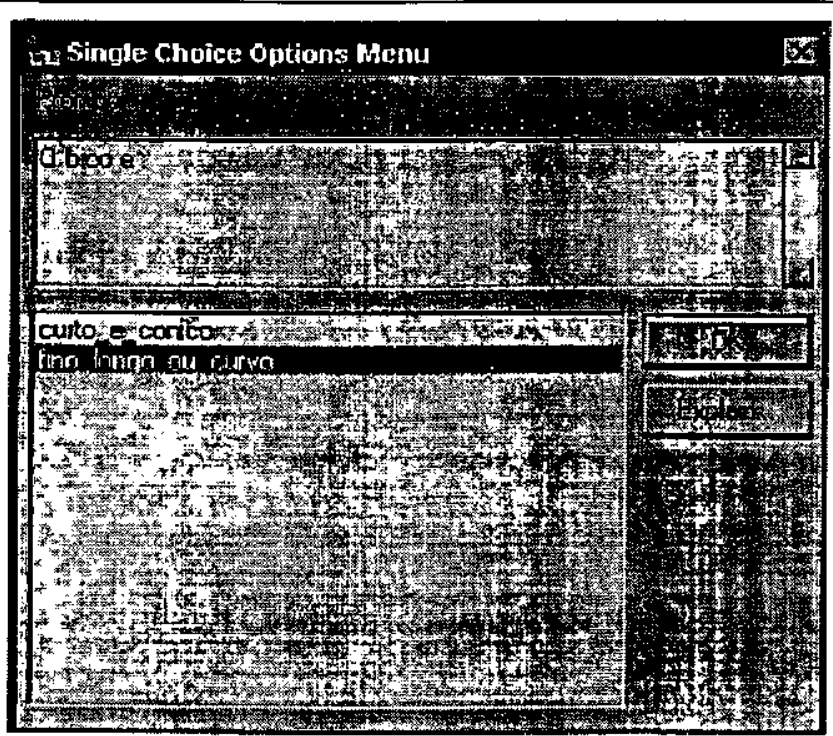

(a)

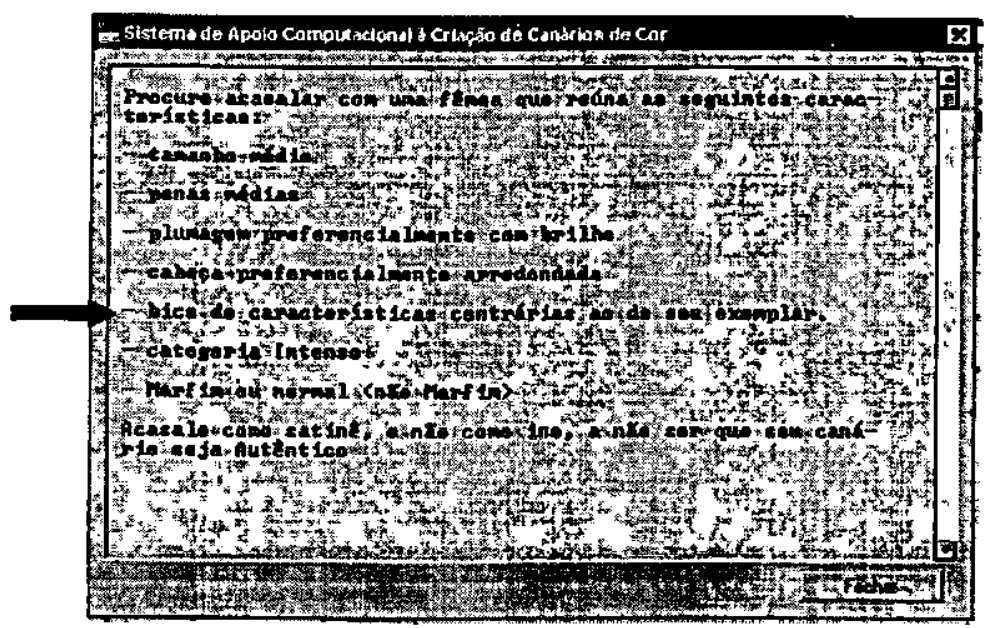

(b)

Figura 6.3 (a) - Janelas do módulo de Aconselhamentos. 


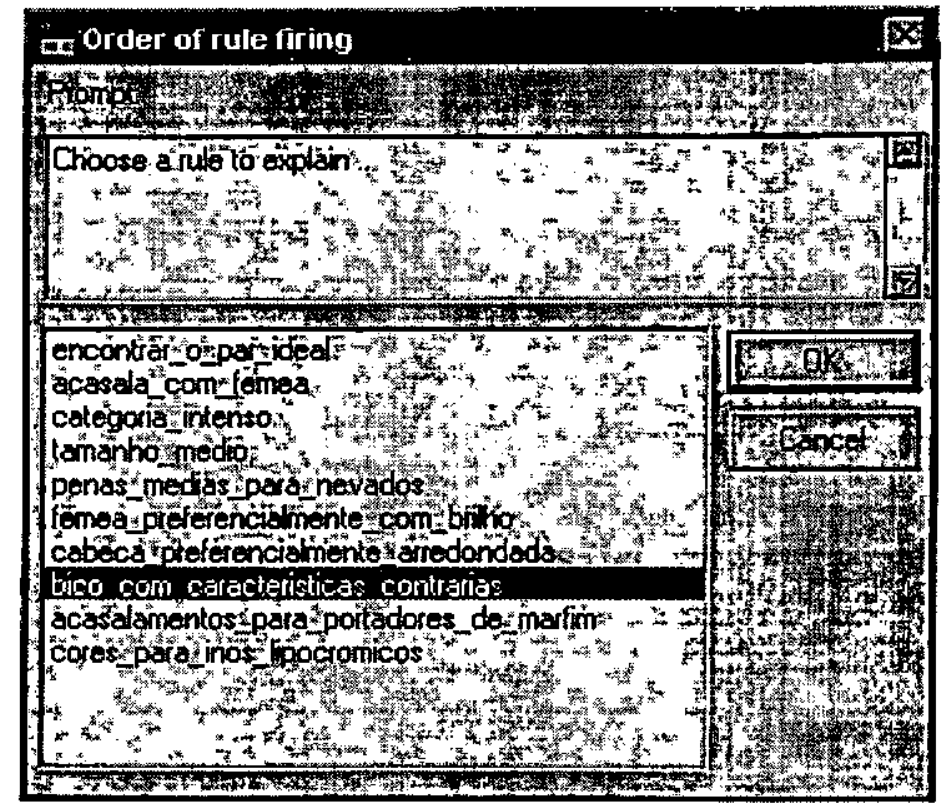

(c)

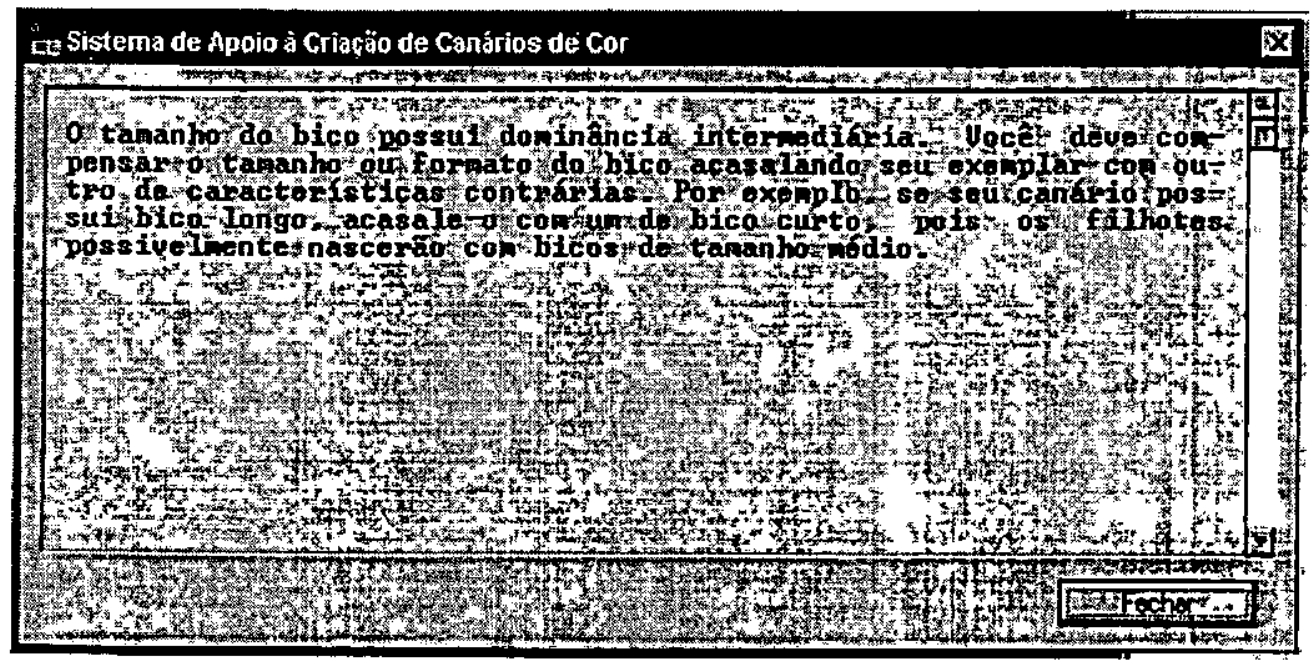

(d)

Figura 6.3 (b) - Janelas do módulo de Aconselhamentos (continuação).

\subsubsection{Validação e Refinamento do sistema}

Vários testes foram realizados no decorrer do projeto a fim de verificar todas as informações inseridas na Base de Conhecimento e também para validar o funcionamento das regras de produção. Uma vez funcionando adequadamente, o sistema foi submetido a um especialista, que fez as últimas correções, complementando algumas informações.

$\mathrm{O}$ módulo Baseado em Conhecimento foi integrado ao resto do Sistema de Apoio à Criação de Canários de Cor e pode ser acionado ao se pressionar o botão Aconselhamentos na 
tela Menu de Apresentação. Não há passagem de informações entre esse módulo e o resto do sistema. Uma integração maior entre os módulos é sugerida em Trabalhos Futuros.

\subsection{Considerações Finais}

LPA-Flex é uma ferramenta que fomece um conjunto de recursos para construção de Sistemas Baseados em Conhecimento. A linguagem KSL dá suporte a variáveis lógicas e globais dentro das regras de produção, o que evita a duplicação desnecessária das mesmas, além de oferecer um sistema pré-definido de perguntas e respostas através de janelas que são construídas automaticamente, contendo botões para confirmação das respostas e para disponibilizar ao usuário as justificativas e explicações associadas às mesmas. No entanto, quando se opta por utilizar os recursos oferecidos pela ferramenta, não se tem flexibilidade para fazer alterações nas janelas nem adaptá-las às necessidades do sistema. Não há como inserir novos botões de comandos nem alterar o tamanho dessas janelas, que não possuem barra de rolagem horizontal. As legendas são mostradas em inglês e não há como traduzi-las. Algumas dessas limitações são divulgadas nos manuais da ferramenta e a sugestão é que se utilize a interface gráfica do sistema Prolog básico (Graphical User Interface). Todos esses problemas afetam a interface do sistema com o usuário e podem ser contornados através rotinas escritas em Prolog, onde é possível criar janelas adaptadas ao sistema. No entanto, ao se criar janelas personalizadas, perde-se algumas das características que a ferramenta oferece, ficando por conta do programador a apresentação da pergunta ao usuário e também o retorno de sua resposta ao programa.

No módulo de Aconselhamentos, a sessão de perguntas e respostas foi desenvolvida utilizando o sistema pré-definido de perguntas e respostas, a fim de aproveitar os recursos que a ferramenta oferece. Já as janelas que apresentam as explicações, justificativas e as soluções ao usuário foram criadas em programas escritos em Prolog, com o objetivo de manter um certo padrão em relação ao resto do sistema. 


\section{Exemplo do Funcionamento do Sistema de Apoio à Criação de}

Canários de Cor

\subsection{Introdução}

Este capítulo traz um exemplo do funcionamento do Sistema de Apoio à Criação de Canários de Cor. As figuras mostram a seqüência de passos que o usuário normalmente seguiria para simular um acasalamento. Nesse exemplo foram escolhidas as cores Branco Dominante para o canário macho e Amarelo Nevado para a fêmea. No resultado final, podem-se observar as probabilidades de se obter filhotes Amarelos Nevados, Brancos Dominantes e Amarelos. Ao entrar no módulo de Aconselhamentos e passar todas as características do macho Branco Dominante, o programa aconselhou o acasalamento com Amarelos Nevados, evitando os Amarelos Intensos. $\mathrm{O}$ acasalamento com outro Branco Dominante só deve ser feito em último caso. Tudo isso é explicado com detalhes na tela de justificativas.

A utilização do sistema nessa ordem, primeiro simular o acasalamento, depois verificar os aconselhamentos, tem valor quando o usuário já conhece a melhor opção em termos de cores e deseja verificar apenas as outras características necessárias ao par que deve utilizar no acasalamento. No caso do usuário não saber qual ou quais as cores recomendadas para o seu par, ele poderia inverter a ordem da pesquisa, primeiro passando as características do pássaro e depois entrando no módulo de Acasalamentos para descobrir os resultados que poderia obter utilizando as sugestões de acasalamentos feitas pelo programa.

Para não tornar o exemplo muito extenso, algumas janelas com textos explicativos e justificativas foram omitidas. 


\section{Sustema de tpoce de Creaceäo de Canárias de Cor}

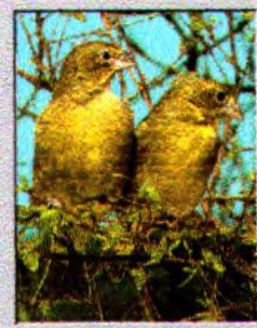

Cadastro de Cores

Consulta Cores

Acasalamentos

Relatório

Aconselhamentos

Sair

\section{Escolher a opção:}

Para entrar no módulo de Acasalamentos, basta pressionar o terceiro botão desta tela.

\section{Escolher a cor do ma-}

cho:

O primeiro passo é escolher a cor do canário macho. Pressionando a seta à direita do campo Fenótipo, a lista das cores cadastradas no Cadastro de Cores é mostrada.

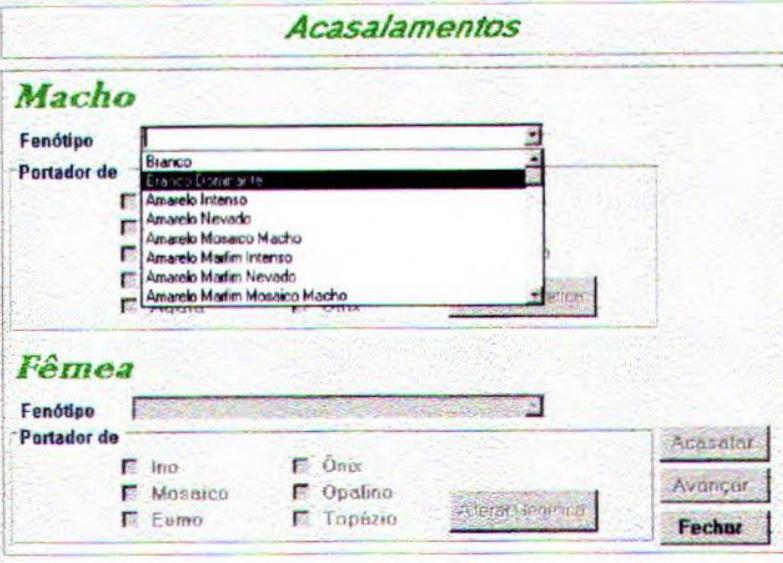

\begin{tabular}{|c|c|c|c|}
\hline & \multicolumn{3}{|c|}{ Acasalamentos } \\
\hline \multicolumn{4}{|c|}{ Macho } \\
\hline Fenótipo & $\sqrt{B \times 1 \times 000 \text { Deningrits }}$ & & $\exists$ \\
\hline & 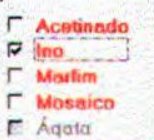 & 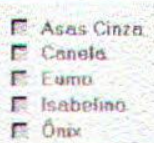 & $\begin{array}{l}\text { r Opaino } \\
\Gamma \text { Pastel } \\
\Gamma \text { Tophizo } \\
\text { Anerar Genético }\end{array}$ \\
\hline
\end{tabular}

\section{Fêrnea}

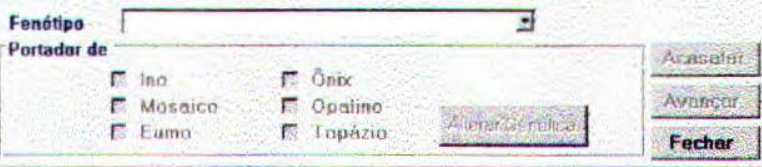

3. Indicar de quais genes 0 macho é portador Um canário macho pode ser portador de até 13 características. Os campos ativados dependem da cor escolhida. O canário Branco Dominante, p. ex., só pode ser portador de Acetinado, Ino, Marfim e/ou Mosaico.

\section{Alterar Genética}

Pressionando o botão "Alterar Genética" aparecerá uma janela onde o usuário poderá informar mais detalhes a respeito das características do pássaro. $\mathrm{O}$ Genótipo $\mathrm{Pa}$ drão que aparece na parte superior da tela corresponde ao código genético do $\mathrm{Ca}$ dastro de Cores.
Genótipo Padrăo

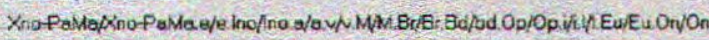

Fator para o Amarelo

- Amerelo Fraco (ae)

C Amarelo Médio (Ae)

$r$ Amarelo Forte (AA)

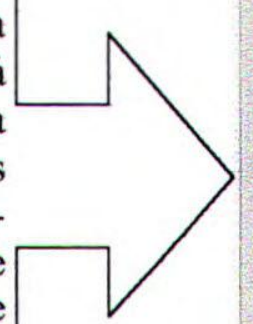

ator para o Intens

$C$ intenso $2 \mathrm{~F}$ (II)

S Intenso $1 \mathrm{~F}$ (bi)

- Nevado (ii)
Fator pare o Vermelho

- Sem Fator

5 Vermalho Freec in

S Vermelho Médio ( $W$

$r$ VermelhoForte (M)

Portador de Branco

$r \operatorname{Sim}(B r b r)$

6 Nắ paret
Fator pare o Azul

$r$ Semfator (LL)

5 Merotimão (L)

(c Limão (ii)

Fator para Branco Dominante

- 1 Fator (Bdbc)

$r_{2}$ Fatores (BdBd) 


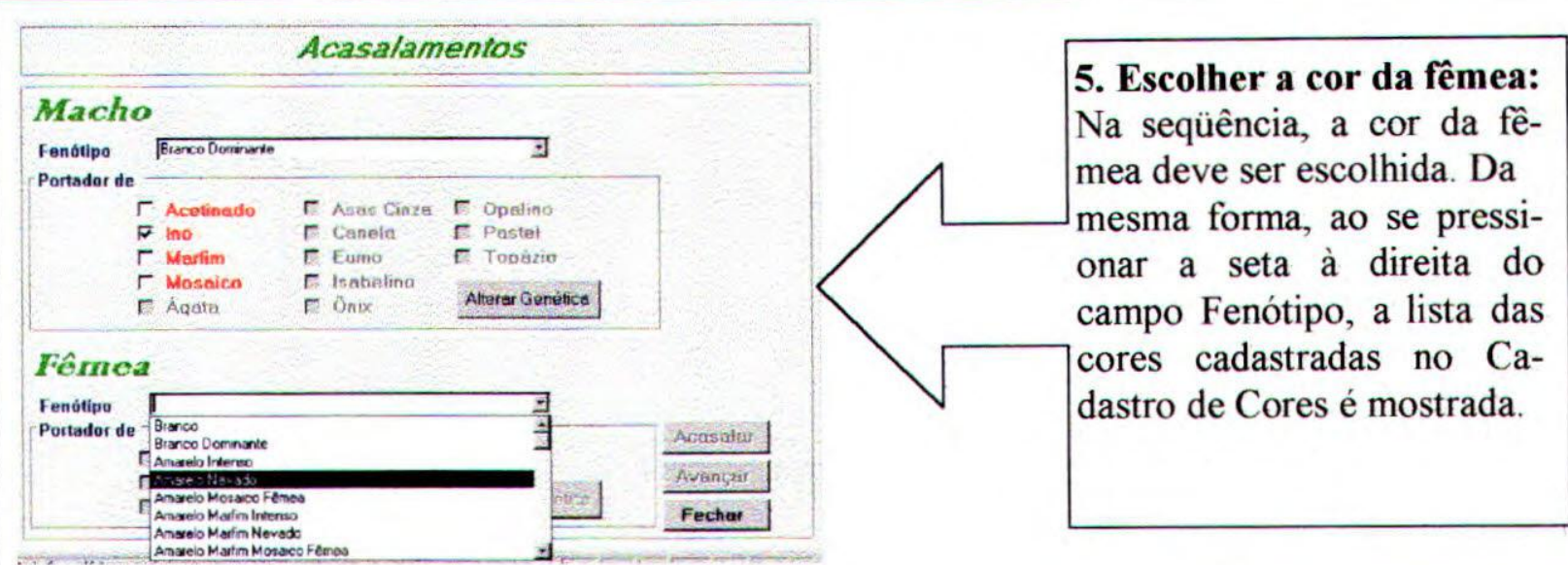

\section{Indicar de quais genes a} fêmea é portadora

Um canário fềmea só pode ser portadora de no máximo 6 características. Os campos ativados dependem da cor escolhida. Uma fềmea Amarelo Nevada, p. ex., só pode ser portadora de Ino e/ou Mosaico
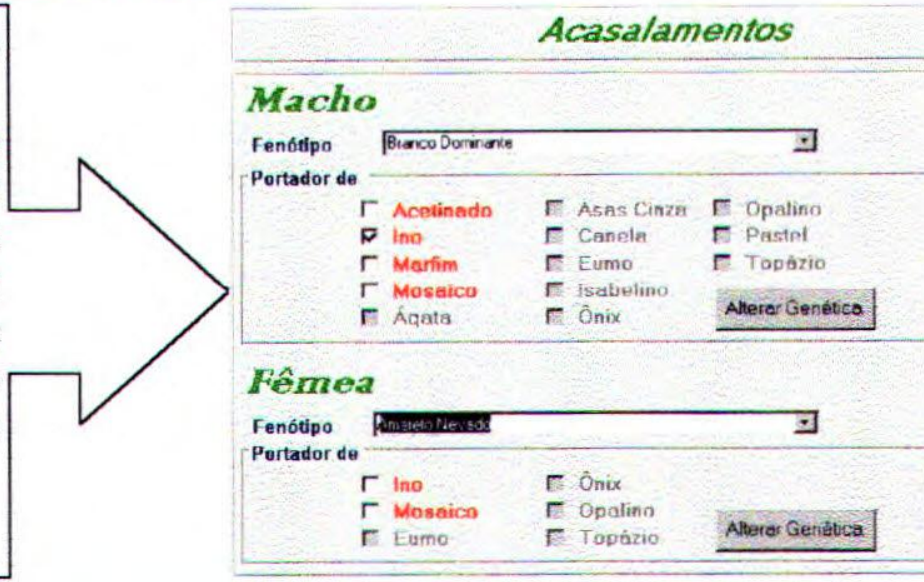

\section{Fổmea}
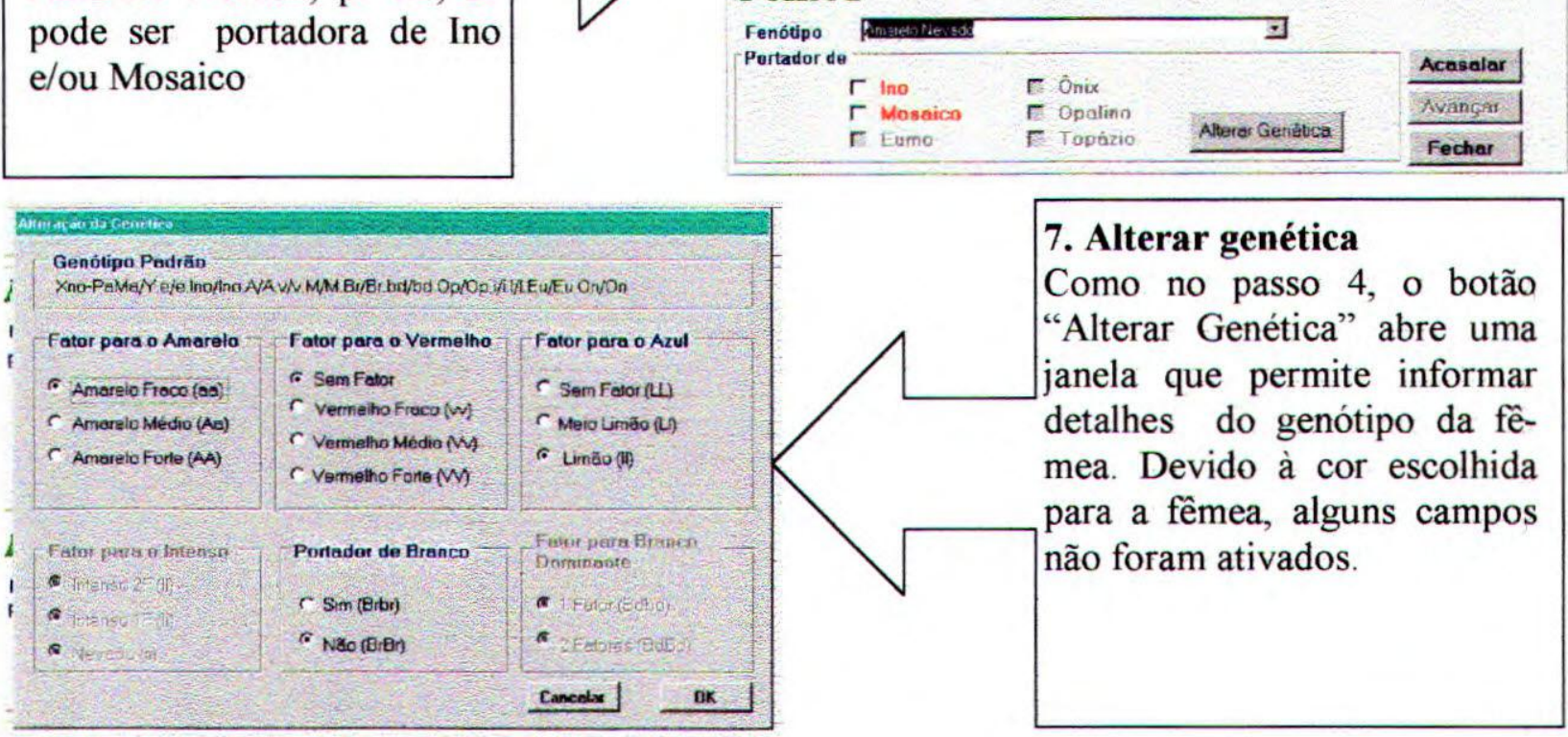

\section{Verificar resultados (1):}

Após fechar a janela anterior e pressionar o botão "Acasalar" da tela Acasalamentos, o sistema mostra uma tela com o resultado do acasalamento. Os códigos genéticos do macho $\mathrm{e}$ da fêmea são agora mostrados com as alterações introduzidas pelo usuário.

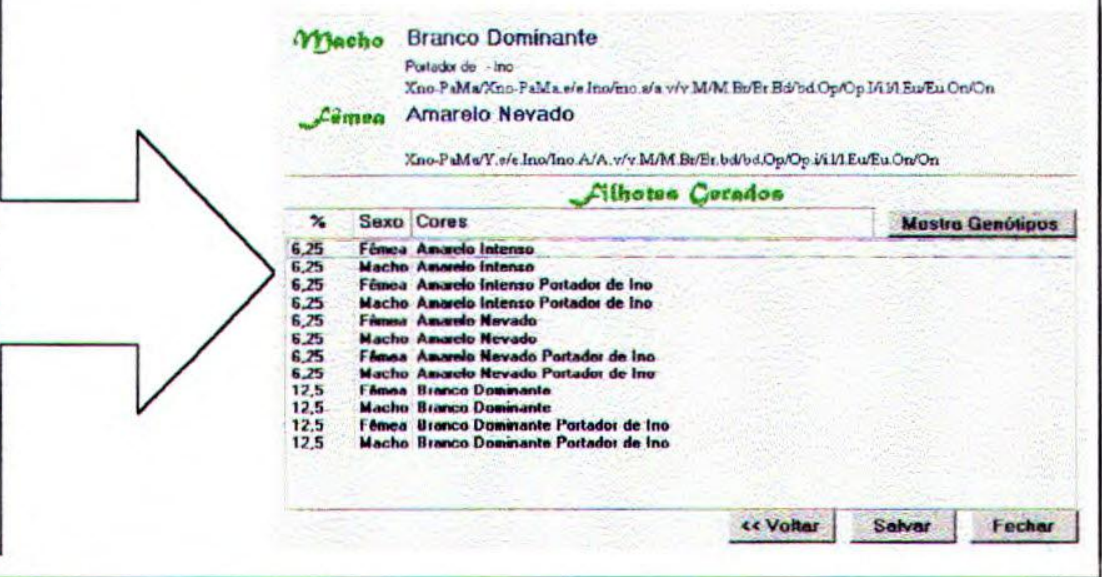




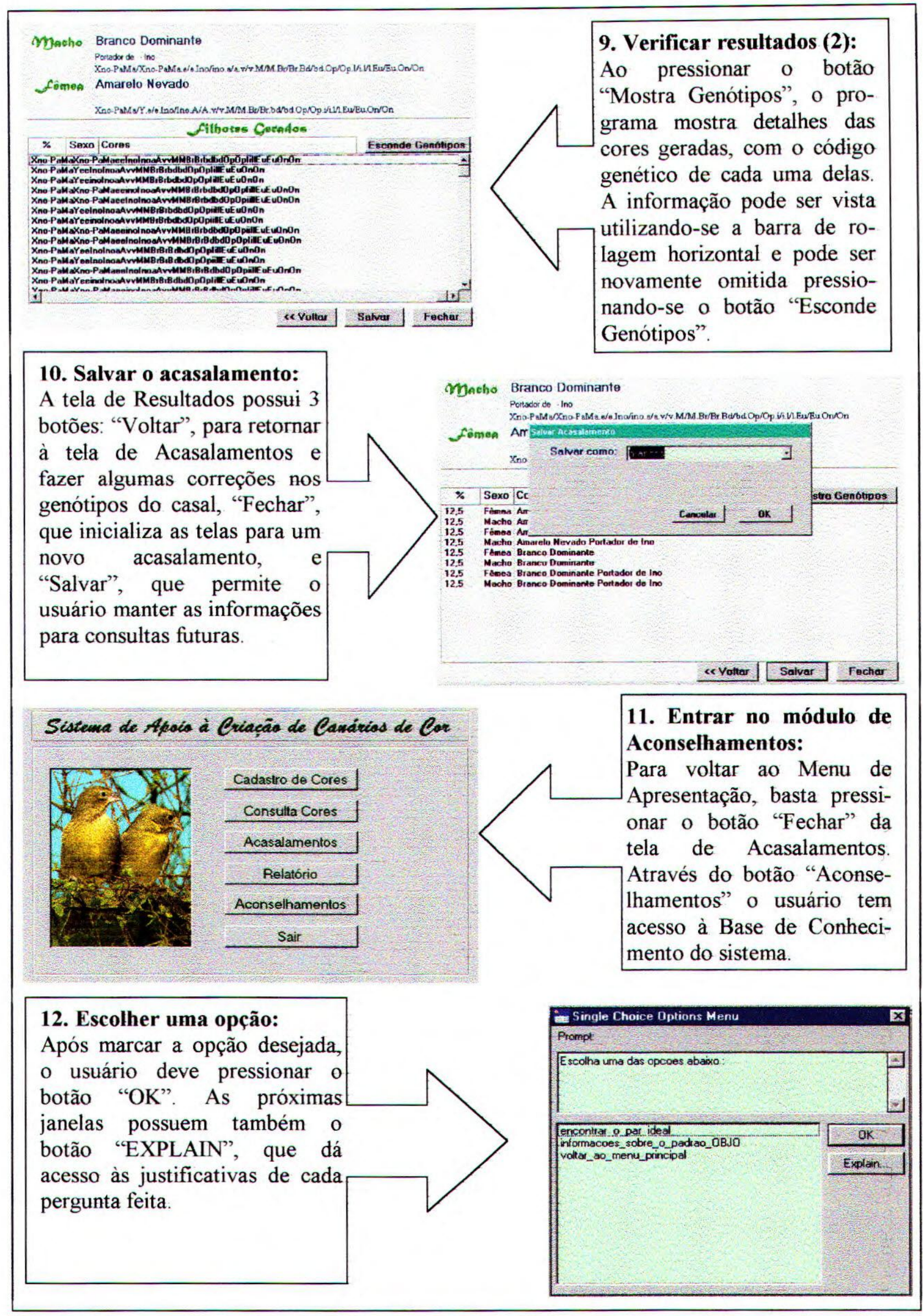




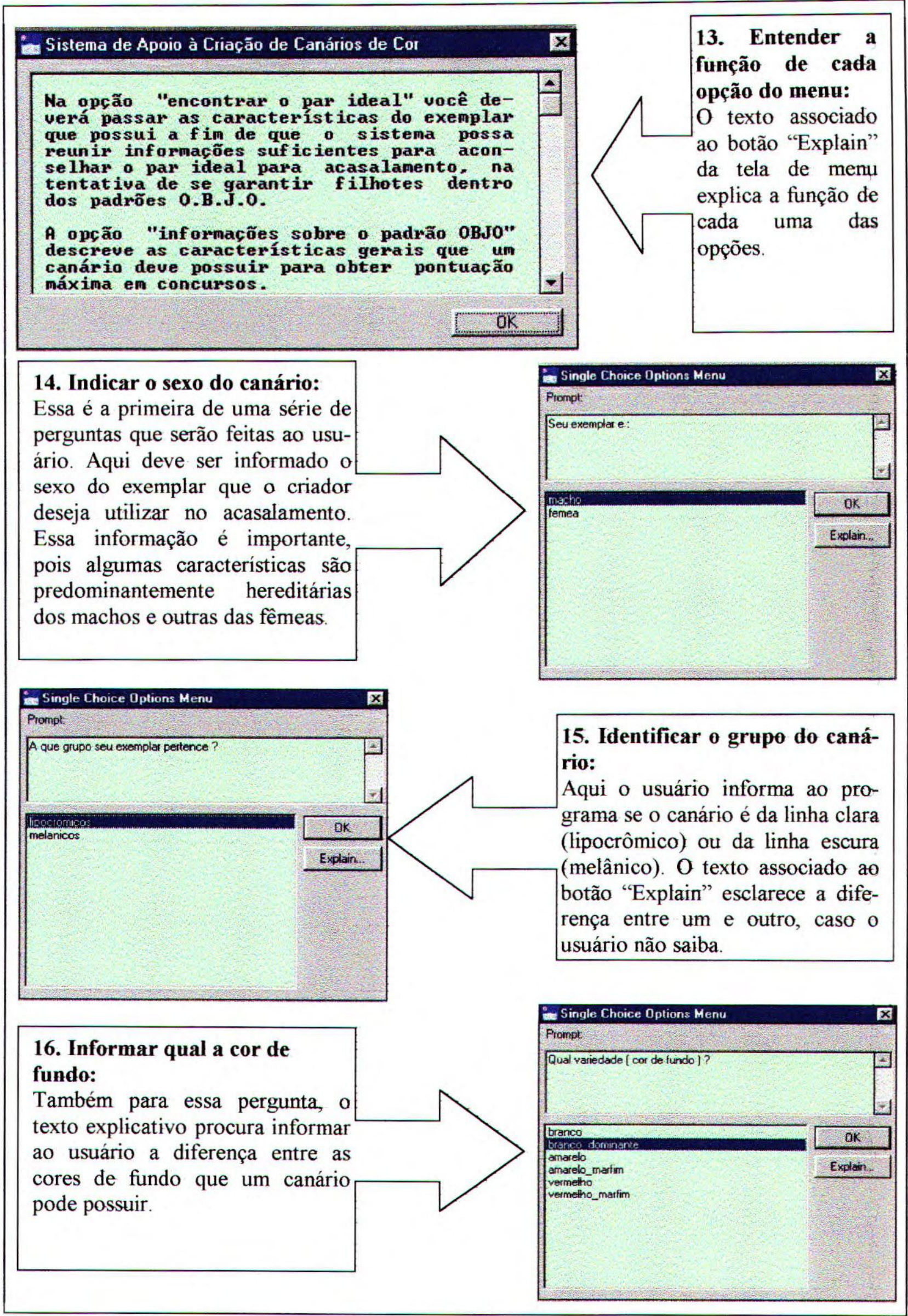




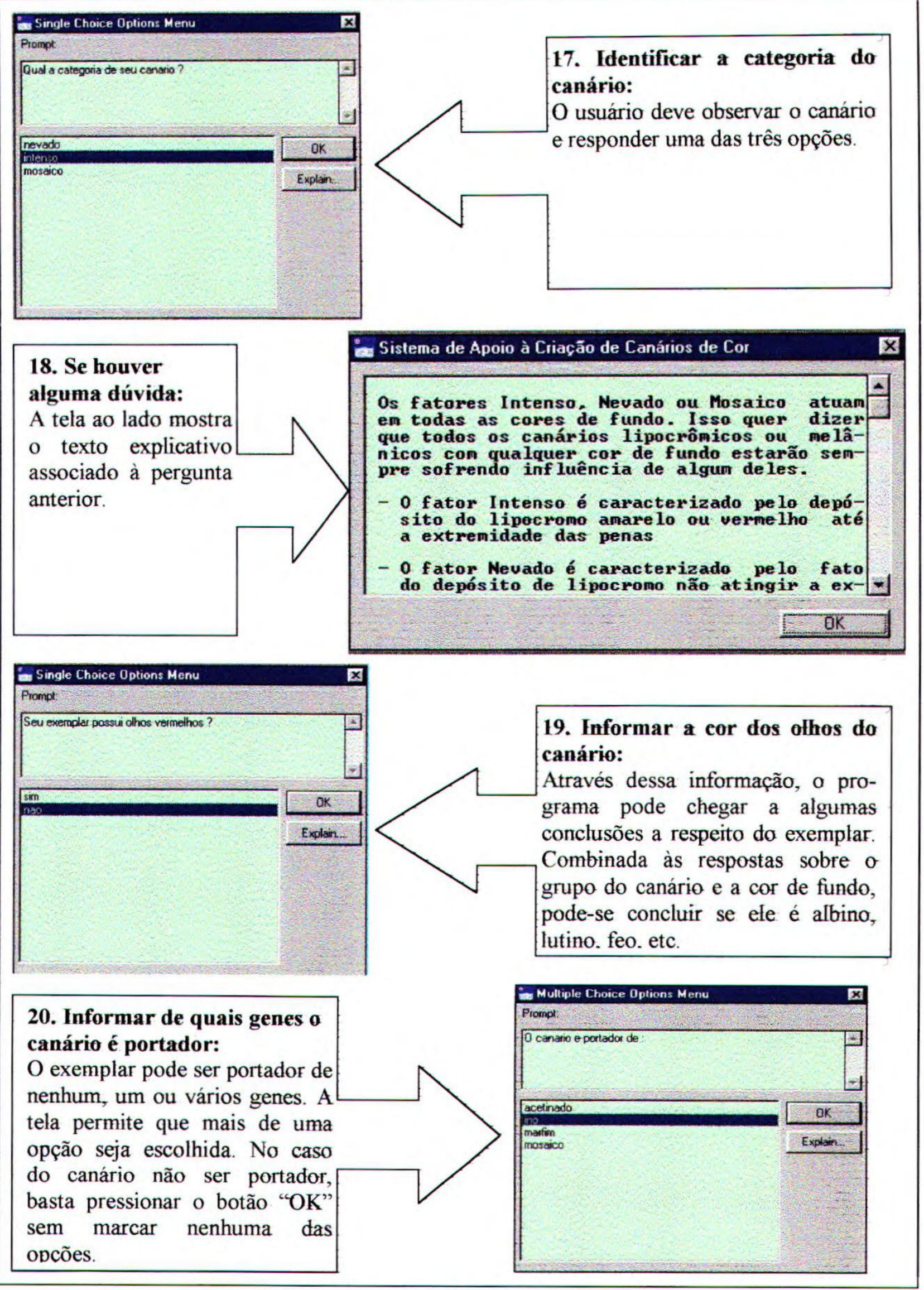




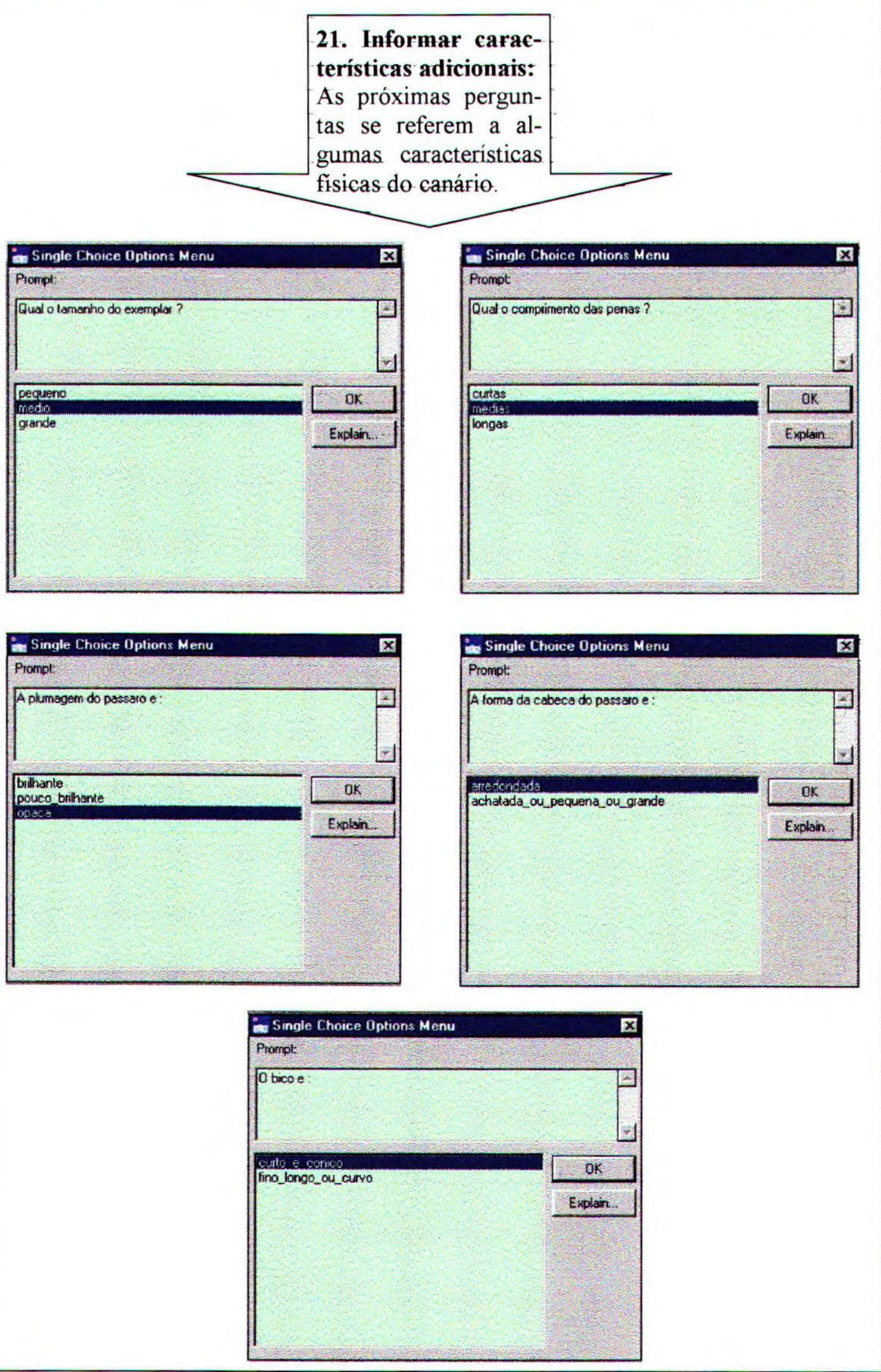




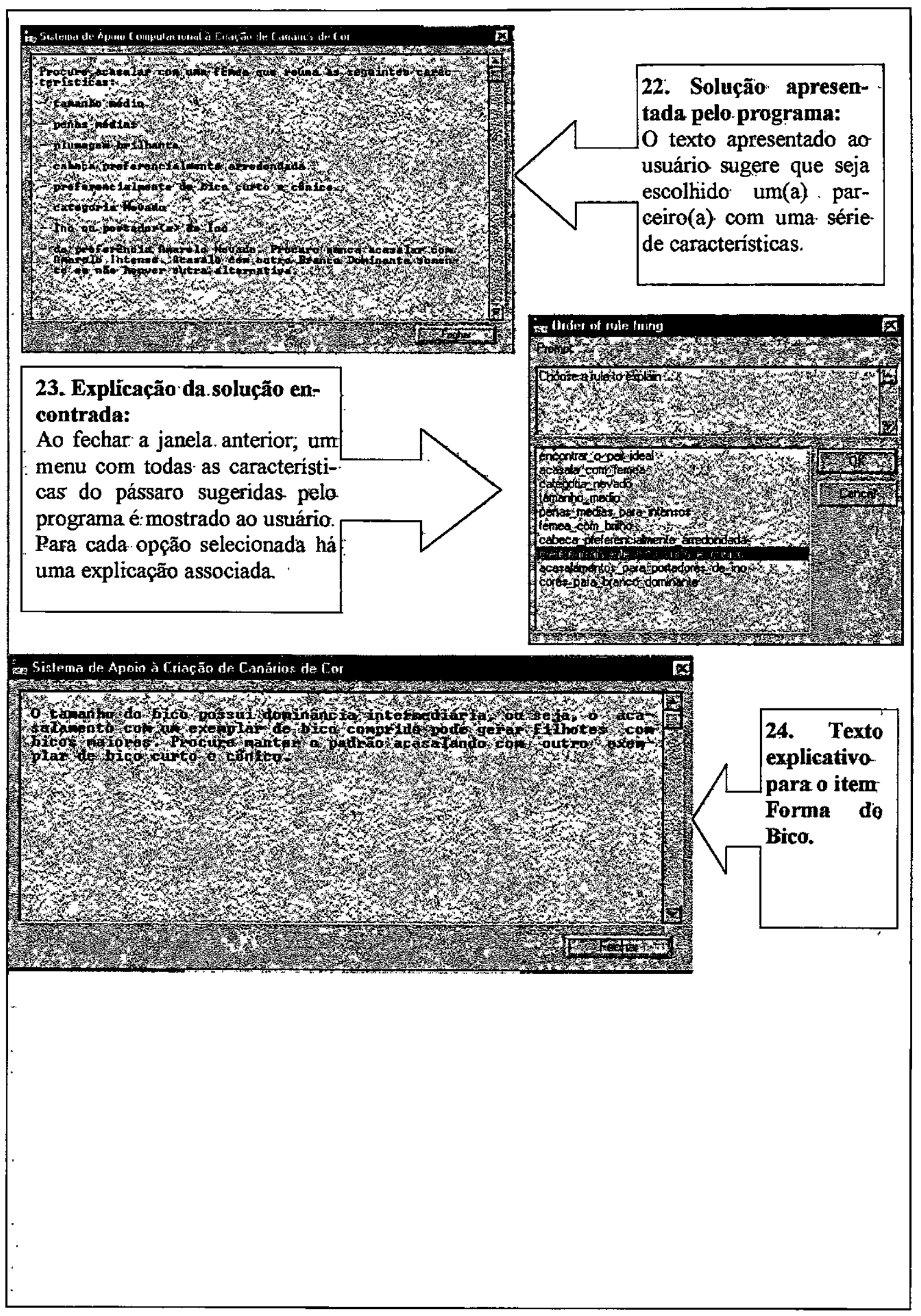




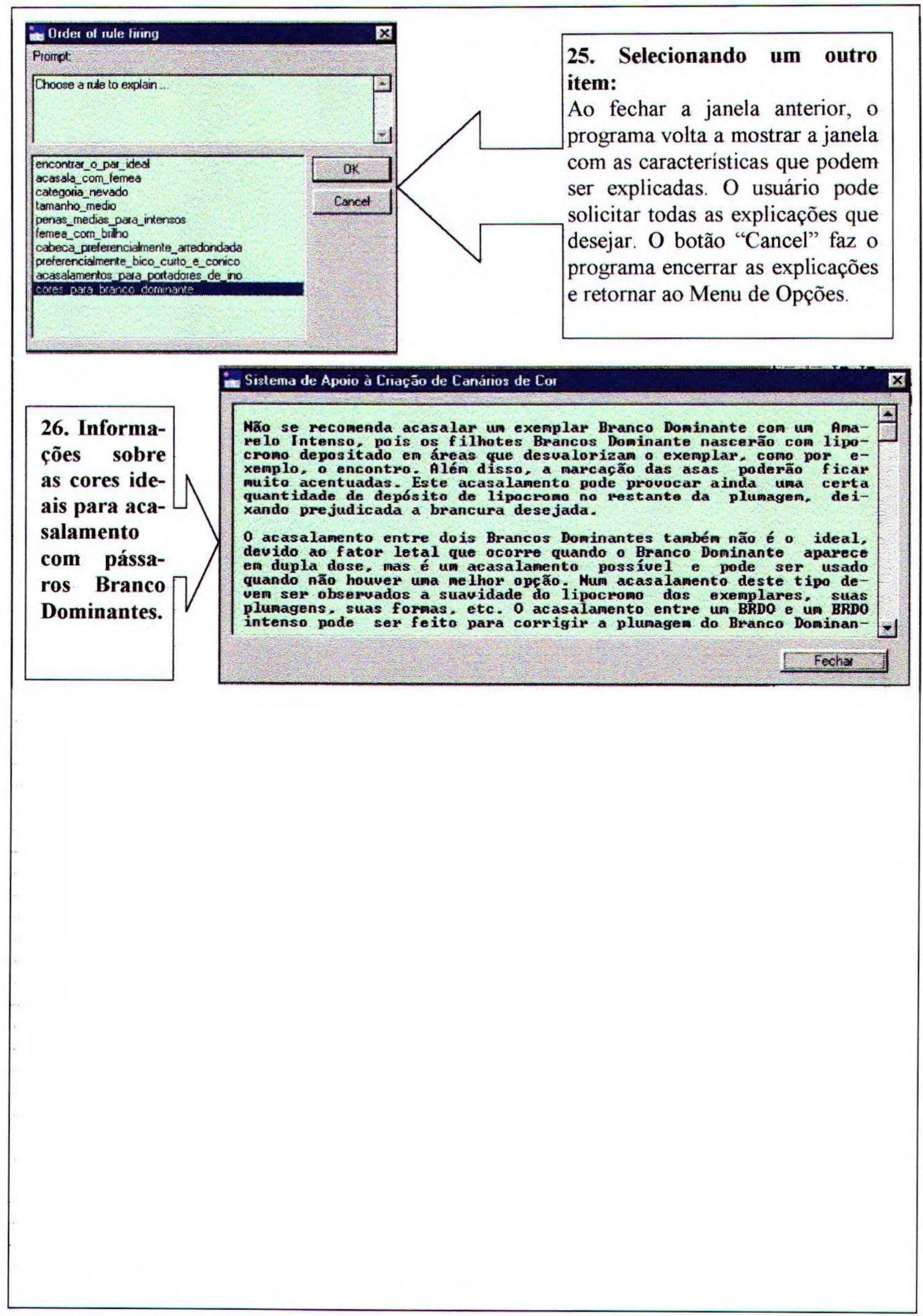


Conclusóes

\subsection{Consideraçōes Iniciais}

Técnicas de Inteligência Artificial e de Engenharia de Software foram utilizadas com o objetivo de criar um software com a finalidade de auxiliar o usuário em tarefas relacionadas à criação de canários de cor. Para tornar isso possível, foram feitos levantamentos sobre as ferramentas que seriam utilizadas e um estudo aprofundado sobre a genética responsável pela coloração dos canários envolvendo toda a evolução que ocorreu desde o canário ancestral até a última mutação descoberta. Também foi feito um trabalho de codificação genética das 358 cores que constam no Cadastro de Cores do sistema, além de um levantamento sobre o conhecimento adquirido com a criação de canários de cor, cientificamente comprovados ou não.

\subsection{Conclusões}

É bastante comum encontrar sistemas desenvolvidos na área de Inteligência Artificial que utilizam estritamente técnicas dessa área. Mais comum ainda são os sistemas puramente baseados na programação convencional, tão divulgados comercialmente. $O$ ponto mais interessante deste trabalho foi justamente a união dessas duas áreas no desenvolvimento de um único software e, apesar de não haver uma maior integração entre os módulos, a implementação é possível de ser feita.

Há muita semelhança entre as duas metodologias com relação aos passos necessários para se desenvolver um software:

- Antes de mais nada, é necessário ter um conhecimento completo do domínio do problema e identificar suas características;

- Técnicas de entrevistas são utilizadas para extrair o conhecimento do usuário e/ou especialista;

- Estruturas devem ser projetadas para organizar dados ou conhecimento;

- Após a implementação, testes e refinamentos devem ser realizados;

- Etc.

A grande diferença está na forma de manusear as informações. Na programação convencional, um banco de dados pode ser criado para manter e relacionar os dados de forma 
organizada. Já em um Sistema Baseado em Conhecimento, o conhecimento é organizado e relacionado através de regras de produção, por exemplo. $O$ papel do Engenheiro de Conhecimento e do Analista de Sistemas é bastante parecido, mas o do projetista ou programador é completamente diferente. Também as ferramentas para desenvolvimento de softwares nas diferentes metodologias possuem muito pouco em comum.

A ferramenta MS-Access foi bastante adequada para se desenvolver o módulo de Acasalamentos. Ela conta com um gerenciador de banco de dados, oferece recursos para geração de interfaces amigáveis e modernas, dentre elas, os botões de comando, facilidades de navegação dentro do sistema, possibilidade de se criar auxílios em tempo de execução (help on-line), entre outras. É também uma ferramenta que pode ser dominada em pouco tempo. Apesar disso, algumas dificuldades foram encontradas e por diversas vezes houve a necessidade de se escolher caminhos alternativos para se chegar ao objetivo pretendido.

Também o LPA-Flex se mostrou a ferramenta mais adequada para o desenvolvimento do módulo de Aconselhamentos. No entanto, a falta de manuais mais completos e bem organizados dificultou o aprendizado e um tempo maior do que o previsto foi gasto até se obter o domínio necessário da linguagem antes de iniciar as implementações. A ferramenta conta com help online, mas os comandos da linguagem KSL não foram incluídos e a sintaxe para o mesmo comando pode ser diferente quando usada em KSL e quando usada em Prolog.

Após estudar o funcionamento do motor de inferência e a forma como ele manipula as regras. descobriu-se que o módulo em questão poderia ser desenvolvido utilizando uma ferramenta para programação convencional. Os principais motivos para não utilizar LPA-Flex eram:

- Problema na passagem de parâmetros, pois o Access trabalha com 32 bits e a versão 3.1 do LPA-Flex, com 16 bits

- Limitação dos programas em apenas 30 Kbytes, impostas pelo editor

- A dificuldade criada pela deficiência dos manuais e falta de exemplos

- A faita de padronização

- A limitação da linguagem KSL com relação à interface com o usuário

Em compensação, criar o mesmo ambiente que a ferramenta LPA-Flex oferece através de uma linguagem de programação convencional seria complicado e tomaria muito tempo de desenvolvimento, apesar de possivel. Por ser o módulo de Aconselhamentos um sistema baseado em regras de produção, não seria difícil transformá-lo em comandos do tipo IF-THEN-ELSE, mas muito trabalho teria que ser dispensado para simular o funcionamento do motor de inferência, armazenar as regras disparadas, montar uma lógica para explicar o porquê das 
perguntas e justificar as soluções encontradas pelo sistema, demandando um tempo enorme de desenvolvimento.

Analisando o problema em termos de benefícios e perdas, optou-se pela utilização do LPA-Flex e, da mesma forma que no MS-Access, procurou-se contornar as limitações da ferramenta da melhor forma possível, contando com o auxílio do grupo de Inteligência Artificial desta Universidade e também com o grupo inglês, responsável pelo desenvolvimento e suporte do Win-Prolog e LPA-Flex.

O desenvolvimento do módulo de Aconselhamentos em uma linguagem de programação convencional traria a vantagem de manter a qualidade das janelas que fazem a interface com o usuário, além de facilitar a passagem de parâmetros entre um módulo e outro. No entanto, não se sabe como seria o desempenho do sistema se o LPA-Flex fosse substituído pelo MS-Access, além de comprometer a manutenção da Base de Conhecimento, que perderia a vantagem de estar completamente separada da linguagem de programação.

\subsection{Contribuições deste Trabalho}

Esta dissertação aborda uma aplicação tipicamente multidisciplinar propondo, implementando e testando um produto final completo. As contribuições do trabalho, como não poderia deixar de ser, se inserem em diferentes contextos dentro dessa multidisciplinaridade:

- Para a canaricultura:

- Levantamento bibliográfico e organização de um texto contendo inúmeras informações normalmente pulverizadas nos diversos livros e publicações técnicocientíficas da área;

- Apresentação estruturada das fórmulas genéticas das 358 cores padronizadas pela Ordem Brasileira dos Juizes de Ornitologia;

- Aglutinação do conhecimento básico e avançado necessário para o acasalamento correto de canários de cor;

- Disponibilização de uma ferramenta inovadora para apoio à criação de canários de cor, que possibilita a qualquer criador organizar-se para obter resultados semelhantes aos obtidos pelos mais experientes e renomados criadores.

- Para a área de computação:

- Toda a experiência adquirida e relatada na dissertação sobre o estudo de um domínio de aplicação totalmente não usual para a área de computação, certamente se resume em uma contribuição para nortear futuros trabalhos em áreas correlatas; 
- A experiência adquirida e relatada no trabalho com relação às ferramentas tradicionais e especializadas em Inteligência Artificial também constituem uma importante contribuição que pode guiar futuras pesquisas na escolha de novas alternativas;

- A integração de todas as diferentes ferramentas para solução do problema global, contribui no sentido de mostrar a viabilidade $e$ apontar as vantagens $e$ desvantagens de cada ferramenta na solução de partes específicas do problema;

- $O$ uso do LPA-Flex no módulo relacionado à manipulação do conhecimento permite explicitar suas vantagens nesse tipo de aplicação, apesar de se Ter identificado a possibilidade de se Ter toda a solução obtida de modo convencional. Isto contribui para deixar claro até que ponto vale a pena enfrentar as dificuldades apresentadas por um ambiente desse tipo e quais as razões para se pensar em uma alternativa convencional;

- Por fim, acredita-se que a experiência relatada nesta dissertação sirva de contribuição para guiar o desenvolvimento, implementações e testes de futuros sistemas multidisciplinares.

\subsection{Trabalhos Futuros}

Considerando que este projeto de mestrado gerou um software baseado em diferentes técnicas de programação, várias melhorias podem ser feitas, como:

- Integrar os dois módulos, Aconselhamentos e Acasalamentos, fazendo com que o sistema consiga detectar as informações que já foram fornecidas pelo usuário

- Desenvolver janelas no módulo de Aconselhamentos dentro do mesmo padrão que foi utilizado no módulo de Acasalamentos, com controles que permitam o usuário navegar mais facilmente entre as janelas

- Implementar botões de controle na tela Resultado de Acasalamentos para que o usuário possa ter acesso à foto do canário, além das outras informações sobre as cores dos filhotes que já são mostradas

- Desenvolver um módulo para controle de plantel, para manter um cadastro dos canários, controlar o nascimento dos filhotes, montar a árvore genealógica, integrando esse módulo aos outros já existentes 
Outras sugestões:

- Implementar o motor de inferência e a base de conhecimento em MS-Access, fazendo um estudo comparativo, identificando perdas e ganhos

- Analisar e modificar o software utilizando técnicas de interface homem-máquina

- Distribuir a rotina de combinações genéticas em mais de um processador

- Medir a qualidade do software utilizando técnicas da Engenharia de Software. 


\section{APÊNDICE A}

\section{Glossário}

\section{Alelos}

Genes que ocupam o mesmo locus em cromossomos homólogos [EPM97].

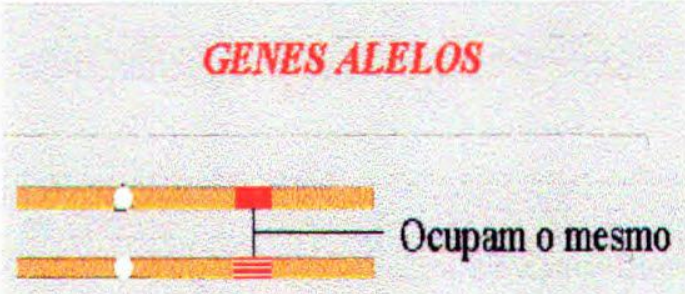

\section{lócus em cromossomos homólogos}

Figura A-1 - Genes alelos [EPM97].

\section{Autossomo}

Qualquer cromossomo que não seja o cromossomo sexual [OLS96]. Um gene do par dos caracteres hereditários [SIL87].

\section{Barbas}

Os filamentos localizados de um e de outro lado da raque das penas [FER88]. Veja figura A5 .

\section{Bárbulas}

Cada um dos pequenos filamentos laterais das barbas das penas [FER88]. Veja figura A-5.

\section{Carotenóides}

Relativo ao caroteno, um corante natural de cor alaranjada, encontrado na manteiga, gema de ovo, em animais herbívoros e também em algumas frutas e vegetais de cor verde escura [FER88].

Cis

Dois ou mais genes que estão no mesmo cromossomo [OLS96]. Os genes mutantes que estão num mesmo cromossomo homólogo [SIL87].

\section{Cromossomo}

Muitos genes ligados em série. Os cromossomos aparecem aos pares em todas as células, exceto em gametas [OLS96]. Partes componentes das células onde se encontram os genes [SIL87]. 


\section{Crossing-over}

Veja Recombinação.

\section{Dimorfismo}

Diferença aparente entre os sexos de uma mesma forma de indivíduos [SIL87]. Características fenotípicas diferentes entre os sexos [SEI96a].

\section{Diplóide}

O número básico de cromossomos de uma espécie denomina-se $n$, portanto, as células diplóides apresentam em seu núcleo 2 n cromossomos [EPM97]. Identifica o número de cromossomos da célula. $O$ número de cromossomos é sempre par em todas as células. exceto gametas. Assim, uma célula possui $2 n$ cromossomos e este número denomina-se número diplóide [SIL87].

\section{Dominante}

Um gene que é visível quando emparelhado com outros genes. $O$ gene mais expressivo de um par cromossômico. Oposto de recessivo [OLS96].

\section{Dorso}

Parte posterior, costas [FER88]. Veja figura A-4.

\section{Epistasia}

Quando um gene impede um outro de se expressar. Os genes poderiam estar no mesmo cromossomo ou em cromossomos diferentes. Mascaramento genético que disfarça o genótipo [OLS96].

\section{Estrias}

Traços coloridos na superfície do corpo [FER88]. Veja figura A-6.

\section{Fator}

Parte de um cromossomo que resulta em uma certa característica [OLS96]. O mesmo que gene [SIL87].

\section{Fenocópia}

Um exemplar é considerado fenocópia de outro quando possui aparência idêntica, mas comportamento genético totalmente diferente [SEI96b].

\section{Fenótipo}

Aparência. O que genes dominantes expressam [OLS96]. É a soma total dos caracteres aparentes em um indivíduo [SIL87]. O fenótipo é a expressão observável de um genótipo como um caracter morfológico, bioquímico ou molecular [EPM97]. 


\section{Feomelanina}

Pigmento marrom que se deposita nas extremidades das penas [SIL87].

\section{Flanco}

Cada uma de duas regiões abdominais laterais, direita e esquerda [FER88]. Veja figura A-4.

\section{Gameta}

Os gametas ou células germinativas masculina e feminina são células sexuais altamente especializadas, que possuem metade do número normal de cromossomos (número haplóide) [EPM97]. Célula com $n$ cromossomos resultante da redução meiótica [SIL87].

\section{Genes}

Uma parte de um cromossomo que resulta em uma certa característica, por exemplo, o gene ou fator para a cor [OLS96]. É a unidade hereditária [EPM97].

\section{Genótipos}

O genótipo de um ser é a sua constituição genética [EPM97][SIL87].

\section{Haplóide}

Característica dos gametas, que possuem cromossomos e não pares de cromossomos [OLS96]. O valor de $n$ cromossomos recebe a denominação de número haplóide.

\section{Heterozigose}

Os genes alelos não são necessariamente idênticos. Quando nas células de um indivíduo os genes alelos para um determinado caráter não são idênticos, o indivíduo é denominado heterozigoto para o caráter denominado pelo par de genes [EPM97].

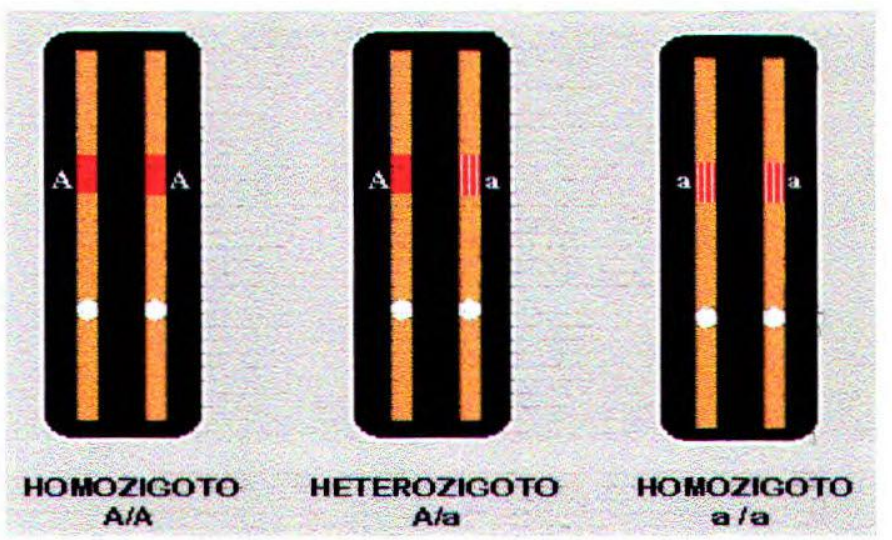

Figura A-2 - Exemplificação de homozigoto e heterozigoto [EPM97].

\section{Híbrido}

Indivíduo resultante do cruzamento de espécies distintas [SIL87]. Um exemplo é o cruzamento do canário com o Tarim para obtenção do fator vermelho. 


\section{Homólogos}

Cromossomos homólogos são membros de um par que possuem informações genéticas equivalentes, isto é, possuem os mesmos loci gênicos na mesma seqüência, mas em qualquer locus específico eles podem ter formas idênticas ou um pouco diferentes, as quais são denominadas alelos.

\section{Homozigose}

Quando os genes alelos são idênticos o indivíduo é denominado homozigoto para aquele caráter [EPM97]. Veja Heterozigose.

\section{Homozigoto}

Veja homozigose.

\section{Ligação Fatorial}

Genes membros de um mesmo cromossomo. Tendência que possuem os genes de um mesmo cromossomo de se transmitirem juntos resistindo à recombinação [SIL87].

\section{Linha Clara}

Canários unicolores, que se compõem de quatro classes de fenótipos básicos: Branco Recessivo, Branco Dominante, Amarelo e Vermelho [VAR95]. Caracteriza-se pela ausência de melanina. Veja detalhes no Apêndice B.

\section{Linha Escura}

Canários bicolores, que se compõem de dez classes de fenótipos básicos: Azul Recessivo, Azul Dominante, Verde, Cobre, Ágata, Canela, Isabelino, Acetinado, Feo e Asa Cinza [VAR95]. Caracteriza-se pela presença de melanina. Veja detalhes no Apêndice B.

\section{Lipocromo}

Pigmento solúvel em gorduras que junto com as melaninas colorem as penas [SIL87].

\section{Loci}

Plural de locus.

\section{Locus}

Ou Locus Gênicos. Os cromossomos existem aos pares nas células somáticas. Cada gene ocupa um lugar definido no cromossomo. Esse lugar definido é denominado locus gênico. Os cromossomos que formam um par possuem os mesmos loci gênicos (loci = plural de locus) e são chamados cromossomos homólogos [EPM97]. 


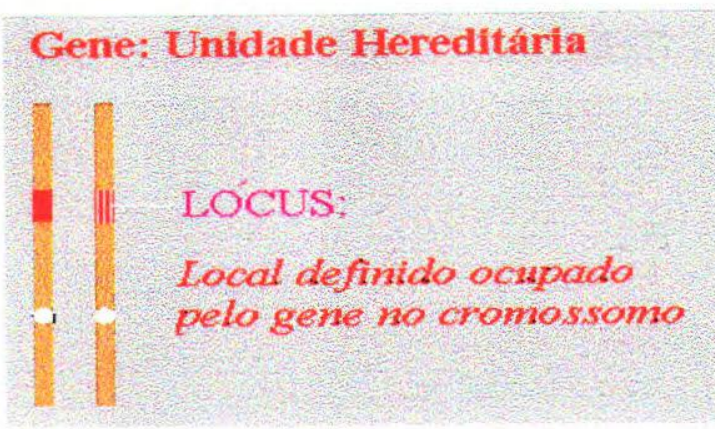

Figura A-3 - Exemplificação de locus [EPM97].

\section{Melanina}

Pigmento negro encontrado em lugares diversos como pele, pelos, etc. [FER88].

\section{Mutação}

Uma mutação é definida como qualquer alteração permanente do DNA. Pode ocorrer em qualquer célula, tanto em células da linhagem germinativa como em células somáticas [EPM97]. Gene modificado [OLS96]. Uma mudança expontânea na função de um gene [SIL87].

\section{Mutação Autossomal}

É qualquer mutação que ocorra em cromossomos diferentes do cromossomo sexual. O resultado da prole, neste easo, independe do sexo dos pais [SEI96b].

\section{Mutação Sexo-Ligada}

É aquela que ocorre no cromossomo sexual. No caso de canários, este cromossoma traz a informação do sexo dos fithotes além de informaȩão para eores, sendo todas reeessivas em relação aos seus alelos originais. Uma característica marcante na mutação sexo-ligada é que a fêmea não pode portar nenhuma destas mutações. Porém, basta o pai conter a informação em seu patrimônio genético (seja mutante ou portador da mutação), para que nasçam fêmeas com fenótipo mutante [SEI96b].

\section{Parcialmente Dominante}

Ou co-dominante ou semi-dominante. O fenótipo apresenta características intermediárias [SIL87].

\section{Queratina}

Proteína insolúvel encontrada nas unhas, pele, cabelo e outros tegumentos animais [FER88].

\section{Raque}

Eixo da pena das aves [FER88]. 


\section{Recessivo}

Um gene que não é visivel quando emparelhado com outros genes. $O$ gene menos expressivo no alelo de um par cromossômico. Oposto de Dominante [OLS96].

\section{Recombinação}

Ou crossing-over, é a troca de partes idênticas de cromossomos que pode ocorrer durante a meiose [SIL87].

\section{Rêmiges}

Penas mais longas das asas das aves [FER88]. Veja figura A-4.

\section{Retrizes}

Penas da cauda que orientam o vôo das aves [FER88]. Veja figura A-4.

\section{Segregação Independente}

É a separação de alelos durante a meiose de forma que cada gameta contenha somente um dos dois alelos. Todo indivíduo carrega dois alelos, um de cada um de seus pais, ou seja, os pais passam somente um alelo dos dois que possuem [OLS96]. É a distribuição aleatória dos cromossomos para a formação dos gametas por ocasião da meiose [SIL87].

\section{Série Alelomórfica}

Existe quando o mesmo gene sofre mais de uma mutação, produzindo efeitos diferentes no fenótipo [SEI96a].

\section{Sexo-ligado}

Caráter hereditário que se situa no cromossomo sexual [SIL87].

\section{Trans}

Quando em cada cromossomo do par existe um alelo primitivo e um mutante [SIL87]. Quando os dois genes em questão estão em cromossomos opostos [OLS96].

\section{Uropígio}

Apêndice triangular sobre as últimas vértebras das aves, no qual se implantam as penas da cauda [FER88]. Veja figura A-4.

\section{Zigoto}

Célula ovo diplóide fertilizada. A primeira célula de um novo indivíduo [OLS96]. 


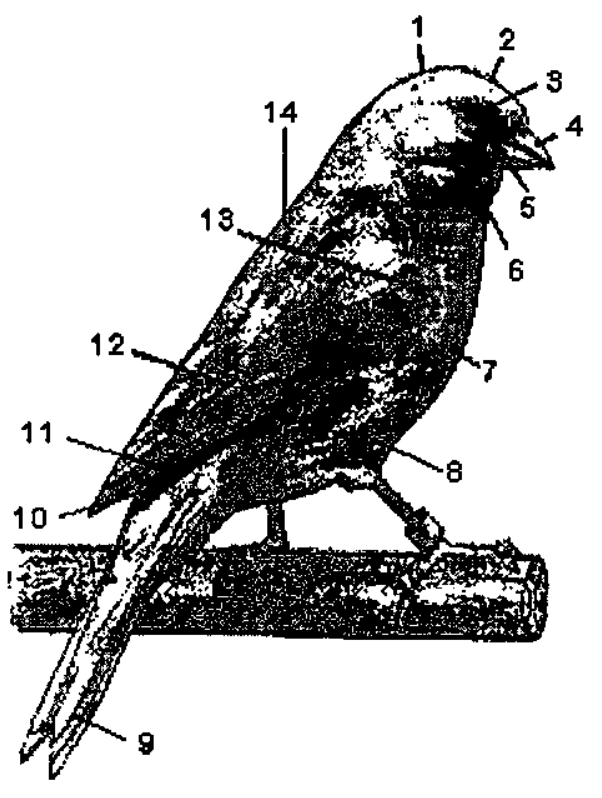

1 - Coroa

2 - Testa

3 - Olhos

4 - Mandfbula ou bico superior

5 - Mandíbula ou bico inferior

6 - Queixo

7 - Peito

8 - Flanco

9 - Retrizes

10 - Uropigio

II - Rêmiges

12 - Asa

13 - Curvatura da asa

14 - Dorso

Figura A-4 - Topografia do Canário [MAT92].

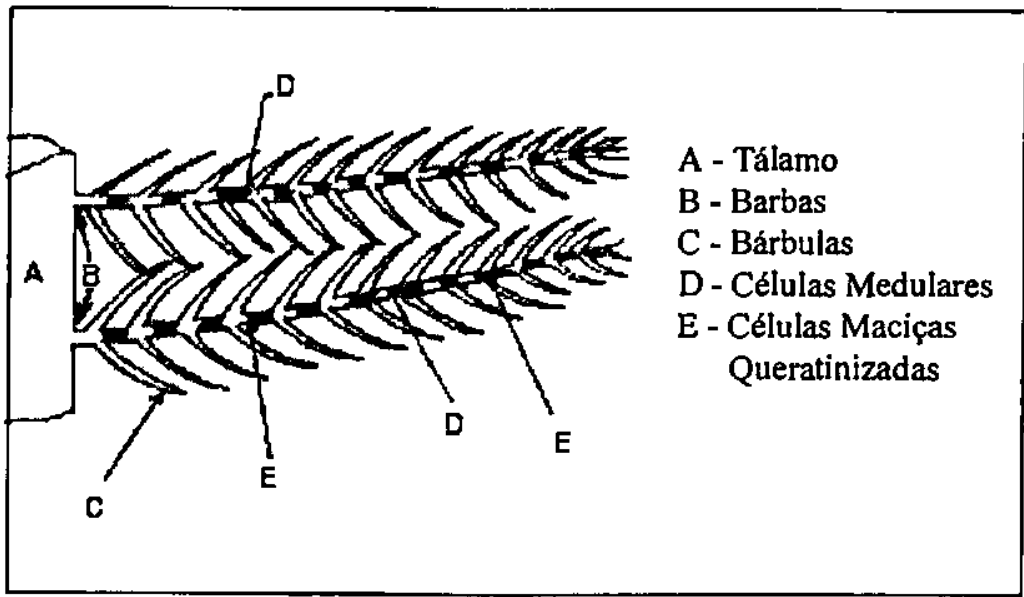

Figura A-5 - Estrutura das penas [SIL87].

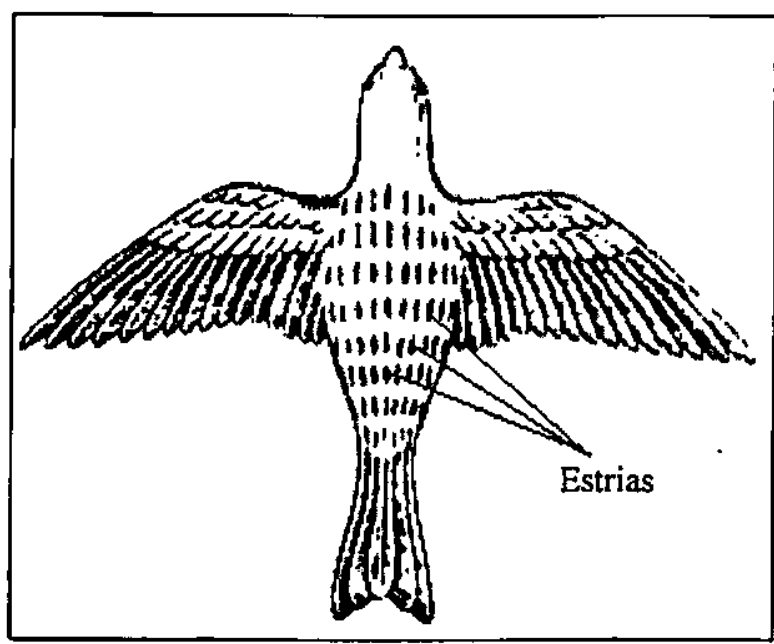

Figura A-6 - Estrias [SIL 87]. 


\section{APÊNDICE B}

\section{A Linha Clara}

Os pássaros pertencentes à linha clara são totalmente destituídos de pigmentos melânicos [WAL87]. Dentro dessa linha existem quatro classes de fenótipos básicos: Branco, Branco Dominante, Amarelo e Vermelho. Com exceção do Branco e do Branco Dominante, as cores podem variar de acordo com a combinação de alguns fatores como o intenso/nevado, marfim e mosaico, este último apresentando fenótipos diferentes, dependendo do sexo do canário [COR95].

Ainda dentro da linha clara, são consideradas as linhas "Ino sem Fator Vermelho" e "Ino com Fator Vermelho", ambas tendo como principal característica canários com olhos vermelhos. $\mathrm{Na}$ linha "Ino sem Fator" os canários possuem cor branca ou amarela, sendo denominados albinos e lutinos, respectivamente. Já os canários rubinos pertencem à linha "Ino com Fator" [COR95].

As cores pertencentes à linha clara e suas possiveis variações são esquematizadas no quadro abaixo:

\begin{tabular}{|c|c|c|}
\hline 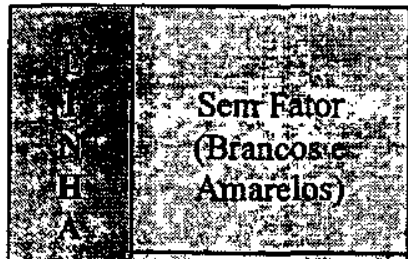 & $\begin{array}{c}\text { Olhos Vermelhos (Albinos } \\
\text { e Lutinos) }\end{array}$ & $\begin{array}{c}\text { Fatores intenso, } \\
\text { nevado, marfim e mosaico. }\end{array}$ \\
\hline 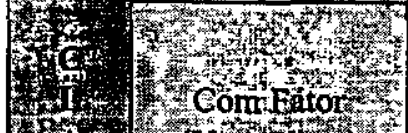 & Olhos Escuros & \multirow{2}{*}{$\begin{array}{c}\text { Fatores intenso, } \\
\text { nevado, marfim e mosaico. }\end{array}$} \\
\hline 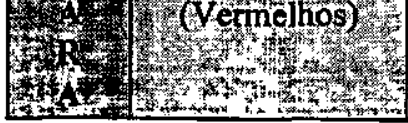 & $\begin{array}{l}\text { Olhos Vermelhos } \\
\text { (Rubinos) }\end{array}$ & \\
\hline
\end{tabular}




\section{A Linha Escura}

Para se entender o "tipo" dos canários pertencentes à linha escura, pode-se imaginar uma capa plástica com desenhos representando estrias negras partindo do alto do dorso e estendendose até o encontro das asas no uropígio. Essas estrias devem também aparecer nos flancos, na cabeça e até no peito. Para os negro-marrons a capa deve ter, fora do desenho formado pelas estrias, uma tonalidade "fumê" com a maior influência de melanina negra possível [COR95].

Ao se colocar essa "capa" sobre um canário de cor Branca, obtém-se um canário Azul. Um canário de cor Amarela se tornaria Verde e, finalmente, um canário Vermelho "vestido" com essa capa se transformaria em um canário Cobre. Quanto mais a melanina negra se misturar com a cor de fundo branca, amarela ou vermelha, melhor a qualidade do pássaro. Essa mistura da parte fumê com a cor de fundo do pássaro é denominada oxidação [COR95].

Por se tratar de pássaros negro-marrons, a cor marrom também deve aparecer no corpo da ave. O marrom pode ter sua origem na melanina marrom, e nesse caso, a cor se localizará nas bordas das penas que formam as estrias negras. Para o marrom originado da feomelanina, a cor se espalhará pelo corpo todo na mesma tonalidade marrom.

Quanto menor a quantidade do marrom, maior o valor do pássaro. Isso porque, enquanto a melanina negra pura das estrias e a melanina que se mistura no resto do corpo com a cor de fundo do canário transformam-se em tonalidades que embelezam o pássaro, a melanina marrom e a feomelanina ofuscam a combinação anterior, tornando o exemplar sem brilho.

Os pássaros negro-marrons devem apresentar patas, unhas e bicos negros. As penas das espáduas (ombros), asas e caudas devem ser de coloração negra e o dorso, flancos e cabeça devem apresentar estrias negras sobre um fundo fortemente oxidado (a oxidação é exatamente o oposto da despigmentação). Também são mais valorizados os exemplares que apresentarem menor quantidade de canela [COR95].

Normalmente as fêmeas possuem maior quantidade de marrom do que os machos e os exemplares intensos normalmente apresentam estrias mais finas do que os nevados [COR95].

Alterando o desenho da capa plástica anterior, através da diluição das melaninas e da transformação das estrias contínuas, tornando-as interrompidas como se fossem fileiras de grãos de arroz, pode-se chegar aos ágatas. Esses "grãos" continuam negros no centro, mas se diluem nas bordas, eliminando a melanina marrom existente nessas áreas, fazendo o pássaro apresentar um tom acinzentado. Assim, as partes da capa fora do desenho dorsal perdem o tom fumê, tornando-se mais transparentes. Os pássaros ágata devem possuir patas e bicos claros [COR95]. 
Essa capa, assim como nos negro-marrons, pode aparecer tanto em um canário de fundo branco, tornando-o um Ágata Prateado, como em um canário amarelo, que passa a ser Ágata Amarelo, ou ainda sobre um vermelho, o qual recebe a denominação Ágata Vermelho.

Uma outra cor classificada dentro da linha escura, o Canela, nada mais é do que um verde onde a melanina negra foi substituída pela marrom. As estrias devem ser largas e contínuas, apresentando o máximo de oxidação possível, proporcionando uma cor marrom, que, quanto mais escura, melhor. Pés e bico devem apresentar tonalidade clara. $\mathrm{O}$ canela sobre um branco origina o canário Canela Prateado e, assim como o ágata, pode atuar também sobre o amarelo e sobre o vermelho [COR95].

Os Isabelinos apresentam somente a melanina marrom fortemente reduzida pelo fator da diluição, que deve ser uniformemente visível sobre o manto, sem manchas claras nos flancos, bordas das rêmiges e retrizes. $O$ isabelino deve possuir pés e bico claros. Como o canela, o fator isabelino sobre cor de fundo branca, origina um canário Isabelino Prateado, e quando sobre amarelo e vermelho origina Isabelino amarelo e Isabelino vermelho, respectivamente [COR95].

Seguindo esse mesmo raciocínio, através de alterações na "capa" utilizada para exemplificar os canários da linha escura, pode-se chegar às mutações Pastel, Opalino, Ino, Acetinado, Asa Cinza, Topázio, Eumo e Ônix.

Os canários Acetinados e Inos possuem olhos de cor vermelha, sendo os últimos denominados $\mathrm{Feo}$, ou seja, dos canários de cor de fundo branca se originam os $\mathrm{Feo} \mathrm{Albinos,} \mathrm{dos}$ de cor de fundo amarela, os Feo Lutinos e, finalmente, dos de cor de fundo vermelha obtém-se os Feo Rubinos [COR95]. 
Exemplificação das possíveis variações das cores da linha escura:

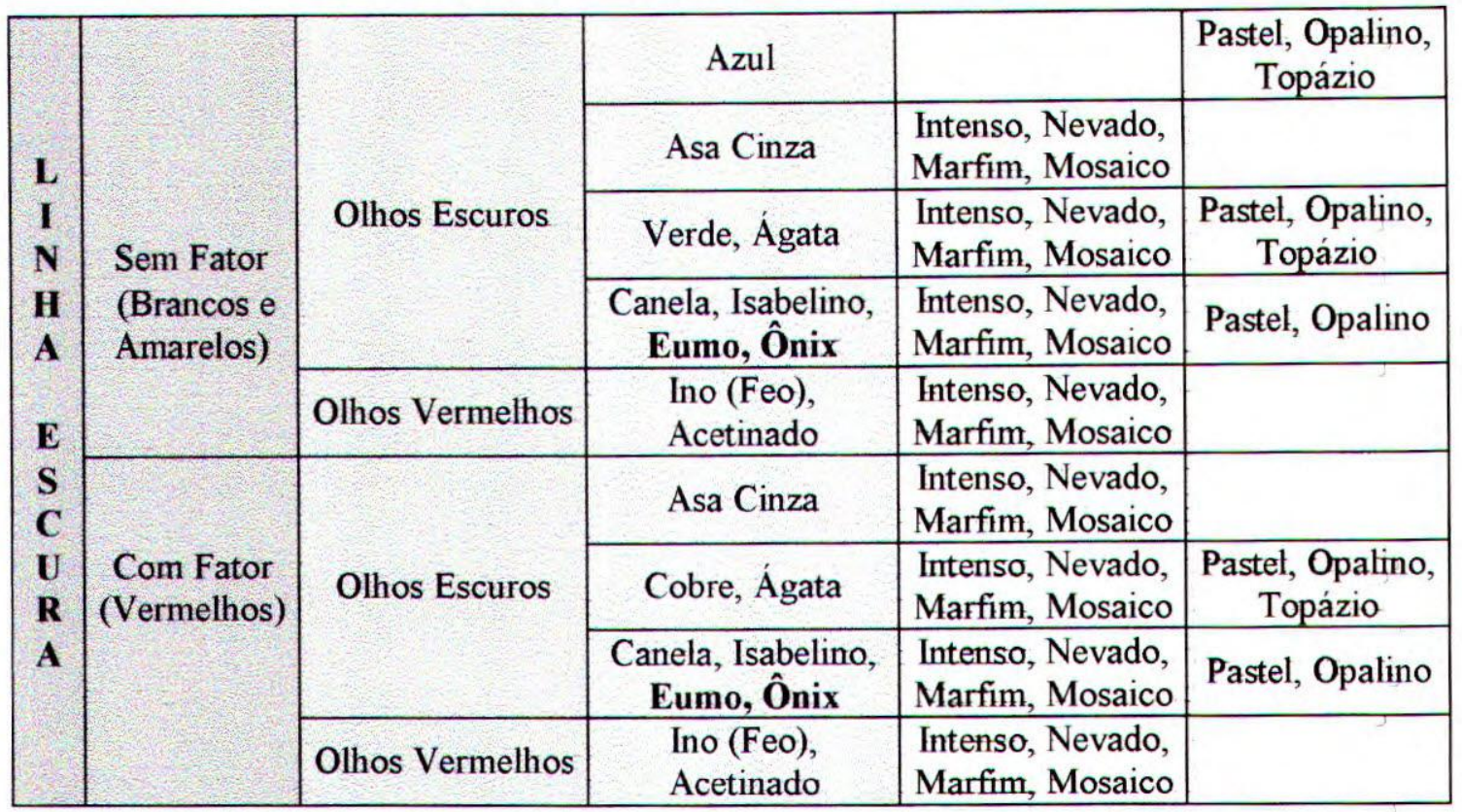

Alguns exemplos de canários da linha clara:

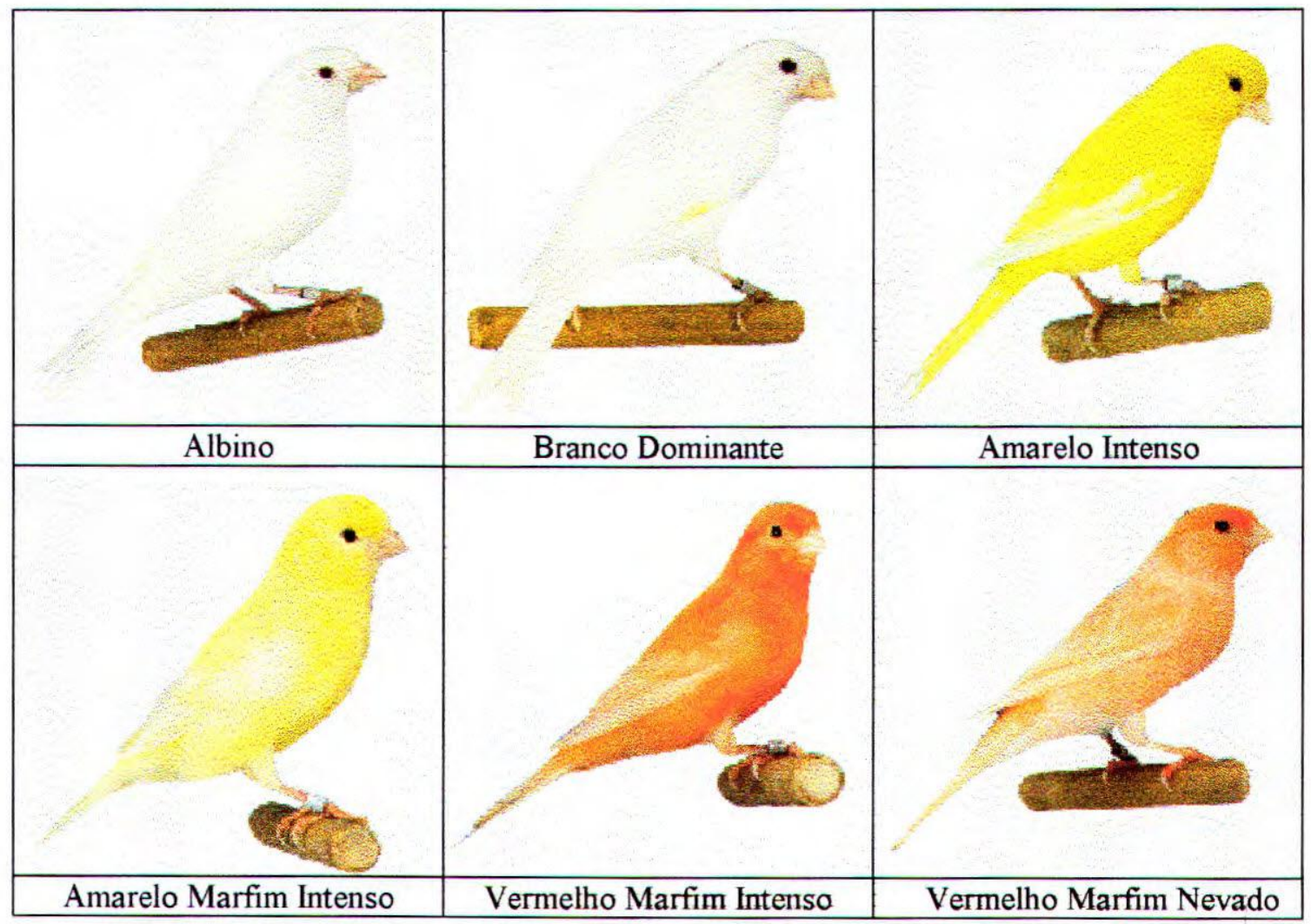

Figura B-1 - Exemplos de canários da linha clara [KEU]. 
Exemplos de canários da linha escura:

\begin{tabular}{|c|c|c|}
\hline & & \\
\hline & & \\
\hline & & \\
\hline
\end{tabular}

Figura B-2 - Exemplos de canários da linha escura [KEU].

Os pássaros Tarim (Pintassilgo da Venezuela) e Canário Selvagem:

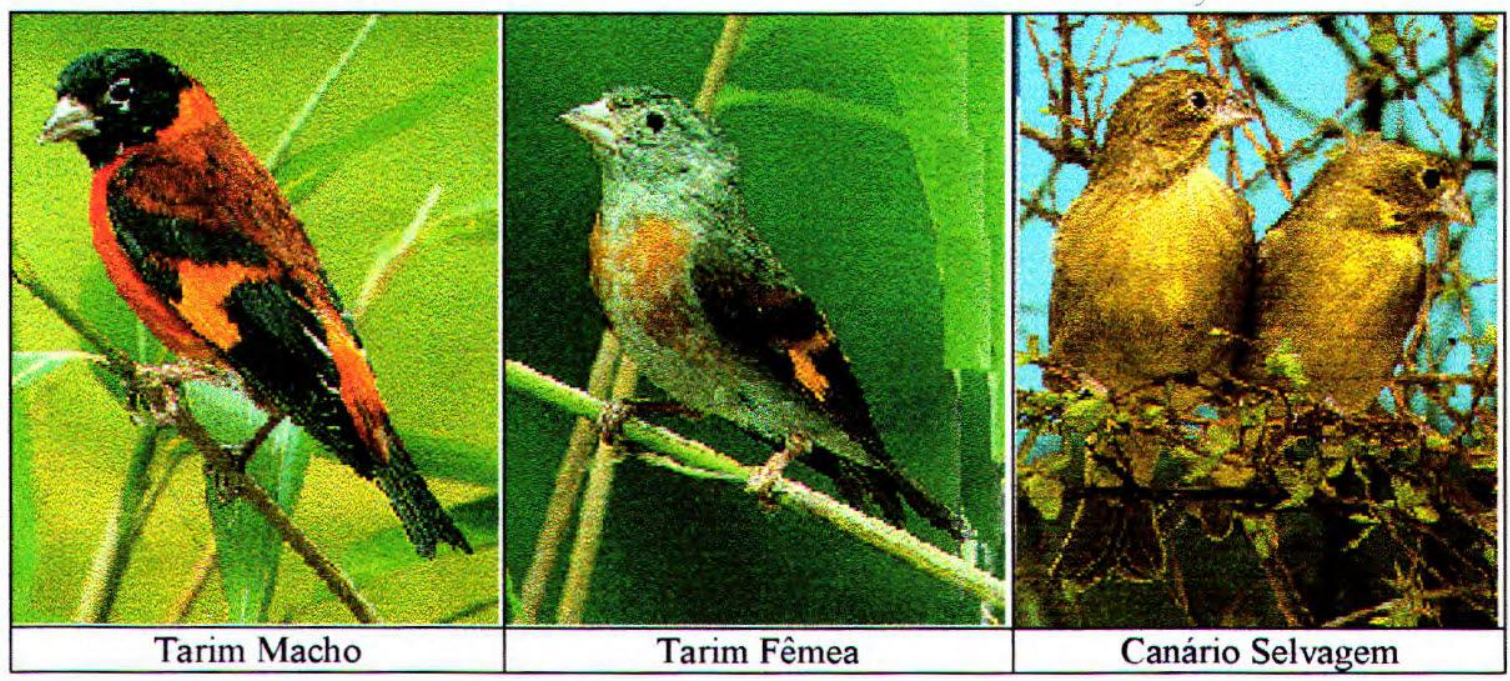

Figura B-3 - Pássaros Tarim e o Canário Selvagem [WAL87]. 
Nomenclatura Oficial O.B.J.O. - Canários de Cor

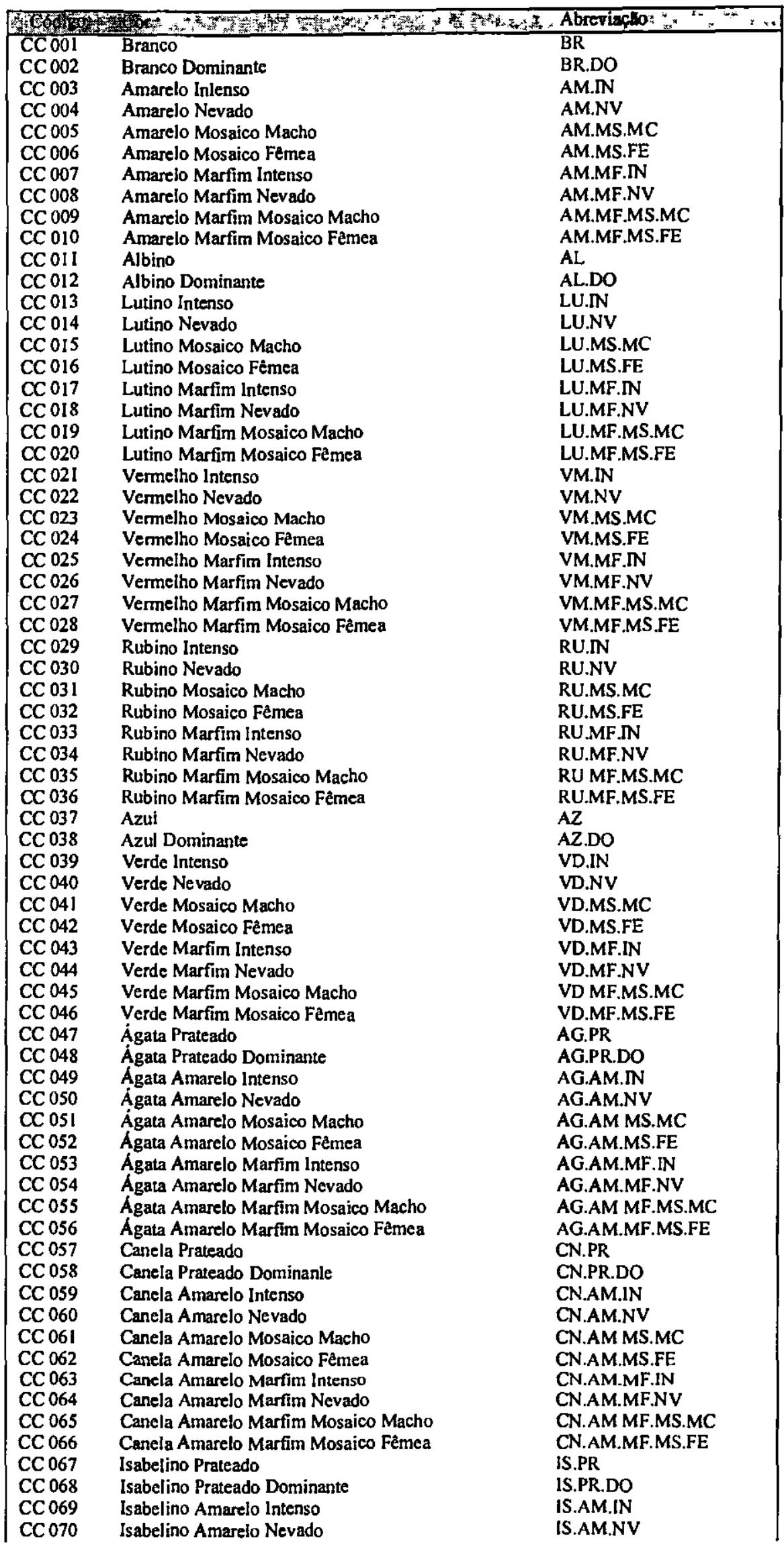




\begin{tabular}{|c|c|c|}
\hline \multicolumn{3}{|c|}{ 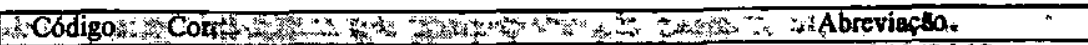 } \\
\hline $\mathrm{CC} 071$ & Isabelino Amarelo Mosaico Macho & IS.AM MS.MC \\
\hline $\mathrm{CC} 072$ & Isabelino Amarelo Mosaico Fêmea & IS.AM.MS.FE \\
\hline $\mathrm{CCO} 073$ & Isabelino Amarelo Marfim Intenso & IS.AM.MF.IN \\
\hline $\mathrm{CC} 074$ & Isabelino Amarelo Marfim Nevado & IS.AM.MF.NV \\
\hline $\mathrm{CC} 075$ & Isabelino Amarelo Marfim Mosaico Macho & IS.AM MF.MS.MC \\
\hline $\mathrm{CC} 076$ & Isabelino Amarelo Marfim Mosaico Fêmea & IS.AM.MF.MS.FE \\
\hline CC 077 & Cobre Intenso & CB.IN \\
\hline $\mathrm{CC} 078$ & Cobre Nevado & CB.NV \\
\hline CC 079 & Cobre Mosaico Macho & CB.MS.MC \\
\hline $\mathrm{CCO} 080$ & Cobre Mosaico Fêmea & CB.MS.FE \\
\hline $\mathrm{CCO} 081$ & Cobre Marfim Intenso & CB.MF.IN \\
\hline $\mathrm{CC} 082$ & Cobre Marfim Nevado & CB.MF.NV \\
\hline $\mathrm{CC} 083$ & Cobre Marfim Mosaico Macho & CB MF.MS.MC \\
\hline CC 084 & Çobre Marfim Mosaico Fèmea & CB.MF.MS.FE \\
\hline CC 085 & Agata Vermelho Intenso & AG.VM.IN \\
\hline $\mathrm{CC} 086$ & Ágata Vermelho Nevado & AG.VM.NV \\
\hline $\mathrm{CC} 087$ & Ágata Vermelho Mosaico Macho & AG.VM MS.MC \\
\hline $\mathrm{CCO} 088$ & Ágata Vermelho Mosaico Fèmea & AG.VM.MS.FE \\
\hline CC 089 & Ágata Vermelho Marfim Intenso & AG.VM,MF.IN \\
\hline $\mathrm{CC} 090$ & Agata Vermelho Marfim Nevado & AG.VM.MF.NV \\
\hline $\mathrm{CC} 091$ & Agata Vermeiho Marfim Mosaico Macho & AG.VM MF.MS.MC \\
\hline $\mathrm{CC} 092$ & Ágata Vermelho Marfim Mosaico Fêmea & AG.VM.MF.MS.FE \\
\hline $\mathrm{CC} 093$ & Canela Vermelho Intenso & CN.VM.IN \\
\hline CC 094 & Canela Vermelho Nevado & CN.VM.NV \\
\hline $\mathrm{CC} 095$ & Canela Vermelho Mosaico Macho & CN.VM MS.MC \\
\hline CC 096 & Canela Vermelho Mosaico Fêmea & CN. VM.MS.FE \\
\hline CC 097 & Canela Vermelho Marfim Intenso & CN.VM.MF.IN \\
\hline CC 098 & Canela Vermelho Marfim Nevado & CN.VM.MF.NV \\
\hline CC 099 & Canela Vermelho Marfim Mosaico Macho & CN.VM MF.MS.MC \\
\hline $\mathrm{CC} 100$ & Canela Vermelho Marfim Mosaico Fêmea & CN.VM.MF.MS.FE \\
\hline $\mathrm{CC} 101$ & Isabelino Vermelho Intenso & IS.VM.IN \\
\hline $\mathrm{CC} 102$ & Isabelino Vermelho Nevado & IS.VM.NV \\
\hline CC 103 & Isabelino Vermelho Mosaico Macho & IS.VM MS.MC \\
\hline CC 104 & Isabelino Vermelho Mosaico Fêmea & IS.VM.MS.FE \\
\hline CC 105 & Isabelino Vermelho Marfim Intenso & IS.VM.MF.IN \\
\hline CC 106 & Isabelino Vermelho Marfim Nevado & IS.VM.MF.NV \\
\hline CC 107 & Isabelino Vermelho Marfim Mosaico Macho & IS.VM MF.MS.MC \\
\hline CC 108 & Isabelino Vermelho Marfim Mosaico Fèmea & IS.VM.MF.MS.FE \\
\hline CC 109 & Azul Pastel & AZ.PT \\
\hline $\mathrm{CC} 110$ & Azul Pastel Dominante & AZ.PT.DO \\
\hline $\mathrm{CC} 111$ & Verde Pastel Intenso & VD.PT.IN \\
\hline $\mathrm{CC} \ 12$ & Verde Pastel Nevado & VD.PT.NV \\
\hline $\mathrm{CC} 113$ & Verde Pastel Mosajco Macho & VD.PT MS.MC \\
\hline $\mathrm{CC} 114$ & Verde Pastel Mosaico Fèmea & VD.PT.MS.FE \\
\hline $\mathrm{CC} 115$ & Verde Pastel Marfim Intenso & VD.PT.MF.IN \\
\hline $\mathrm{CC} 116$ & Verde Pastel Marfim Nevado & VD.PT.MF.NV \\
\hline $\mathrm{CC} 117$ & Verde Pastel Marfim Mosaico Macho & VD.PT MF.MS.MC \\
\hline $\mathrm{CC} 118$ & Verde Pastel Marfim Mosaico Fêmea & VD.PT.MF.MS.FE \\
\hline $\mathrm{CC} 119$ & Ágata Pastel Prateado & AG.PT.PR \\
\hline $\mathrm{CC} 120$ & Ágata Pastel Prateado Dominante & AG.PT.PR.DO \\
\hline $\mathrm{CC} 121$ & Ágata Pastel Amarelo Intenso & AG.PT.AM.IN \\
\hline $\mathrm{CC} 122$ & Ágata Pastel Amarelo Nevado & AG.PT.AM.NV \\
\hline $\mathrm{CC} 123$ & Ágata Pastel Amarelo Mosaico Macho & AG.PT.AM MS.MC \\
\hline CC 124 & Ágata Pastel Amarelo Mosaico Fémea & AG.PT.AM.MS.FE \\
\hline $\mathrm{CC} 125$ & Ágata Pastel Amarelo Marfim Intenso & AG.PT.AM.MF.IN \\
\hline $\mathrm{CC} 126$ & Ágata Pastel Amarelo Marfim Nevado & AG.PT.AM.MF.NV \\
\hline $\mathrm{CC} I 27$ & Ágata Pastel Amarelo Marfim Mosaico Macho & AG.PT.AM MF.MS.MC \\
\hline CC 128 & Ágata Pastel Amarelo Marfím Mosaico Fèmea & AG.PT.AM.MF.MS.FE \\
\hline CC 129 & Cancla Pastel Prateado & CN.PT.PR \\
\hline $\mathrm{CC} 130$ & Canela Pastel Pratcado Dominante & CN.PT.PR.DO \\
\hline $\mathrm{CC}[3]$ & Canela Pastel Amarelo intenso & CN.PT.AM.IN \\
\hline CC 132 & Canela Pastel Amarelo Nevado & CN.PT.AM.NV \\
\hline CC 133 & Canela Pastel Amarelo Mosaico Macho & CN.PT.AM MS.MC \\
\hline $\mathrm{CC} I 34$ & Canela Pastel Amarelo Mosaico Fêmea & CN.PT.AM.MS.FE \\
\hline $\mathrm{CC} 135$ & Caneia Pastel Amarelo Marfim Intenso & CN.PT.AM.MF.IN \\
\hline CC 136 & Canela Pastel Amarelo Marfim Nevado & CN.PT.AM.MF.NV \\
\hline CC 137 & Canela Pastel Amarelo Marfim Mosaico Macho & CN.PT.AM MF.MS.MC \\
\hline CC 138 & Canela Pasıel Amarelo Marfim Mosaico Fêmea & CN.PT.AM.MF.MS.FE \\
\hline CC 139 & Isabelino Pastel Prateado & IS.PT.PR \\
\hline $\mathrm{CC} 140$ & Isabelino Pastel Prateado Dominante & IS.PT.PR.DO \\
\hline $\mathrm{CC} 141$ & Isabelino Pastel Amarelo Intenso & IS.PT.AM.IN \\
\hline $\mathrm{CC} 142$ & Isabelino Pastel Amarclo Nevado & IS.PT.AM.NV \\
\hline $\mathrm{CC} 143$ & Isabelino Pastel Amarelo Mosaico Macho & IS.PT.AM MS.MC \\
\hline
\end{tabular}




\begin{tabular}{|c|c|c|}
\hline endigo & 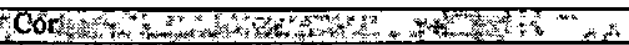 & Abreviaças \\
\hline$\overline{\mathrm{CC}} 144$ & Isabelino Pastel Amarelo Mosaico Fémea & 1S.PT.AM.MS.FE \\
\hline CC 145 & Isabelino Pastel Amarelo Marfim Intenso & IS.PT.AM.MF.IN \\
\hline CC 146 & 1sabelino Pastel Amarelo Marfim Nevado & IS.PT.AM.MF.NV \\
\hline CC 147 & Isabelino Pastel Amarelo Marfim Mosaico Macho & IS.PT.AM MF.MS.MC \\
\hline CC 148 & Is abelino Pastel Amarelo Marfim Mosaico Fèmea & IS.PT.AM.MF.MS.FE \\
\hline CC 149 & Cobre Pastel Intenso & CB.PT.IN \\
\hline CC 150 & Cobre Pastel Nevado & CB.PT.NV \\
\hline CC 151 & Cobre Pastel Mosaico Macho & CB.PT.MS.MC \\
\hline CC 152 & Cobre Pastel Mosaico Fémea & CB.PT.MS.FE \\
\hline $\mathrm{CC} 153$ & & $\begin{array}{l}\text { CB.PT.MF.IN } \\
\text { CBPT MFNY }\end{array}$ \\
\hline CC 154 & $\begin{array}{l}\text { Cobre Pastel Marfim Nevado } \\
\text { Cobre Pastel Marfim Mosaico Macho }\end{array}$ & $\begin{array}{l}\text { CB.PT.MF.NV } \\
\text { CB.PT.MF.MS.MC }\end{array}$ \\
\hline $\begin{array}{l}\text { CC } 155 \\
\text { CC } 156\end{array}$ & & $\begin{array}{l}\text { CB.PT.MF.MS.MC } \\
\text { CB.PT.MF.MS.FE }\end{array}$ \\
\hline CC 157 & Ágata Pastel Vermeiho intenso & AG.PT.VM.IN \\
\hline CC 158 & Ágata Pastel Vermeiho Nevado & AG.PT.VM.NV \\
\hline CC 159 & Ágata Pastel Vermelho Mosaico Macho & AG.PT.VM MS.MC \\
\hline CC 160 & Ágata Pastel Vermeiho Mosaico Fêmea & AG.PT.VM.MS.FE \\
\hline CC 161 & Ágata Pastel Vermelho Marfim Intenso & AG.PT.VM.MF.IN \\
\hline CC 162 & Agata Pastel Vermelho Marfim Nevado & AG.PT.VM.MF.NV \\
\hline CC 163 & Agata Pastel Vermelho Marfim Mosaico Macho & AG.PT.VM MF.MS.MC \\
\hline CC 164 & Agata Pastel Vermelho Marfim Mosaico Fëmea & AG.PT.VM.MF.MS.FE \\
\hline CC 165 & Canela Pastel Vermelho Intenso & CN.PT.VM.IN \\
\hline CC 166 & Canela Pastel Vermelho Nevado & CN.PT.VM.NV \\
\hline CC 167 & Canela Pastel Vermelho Mosaico Macho & CN.PT.VM MS.MC \\
\hline CC I68 & Canela Pastel Vermelho Mosaico Fermea & CN.PT.VM.MS.FE \\
\hline $\begin{array}{l}\text { CC } 169 \\
\text { CC } 170\end{array}$ & $\begin{array}{l}\text { Canela Pastel Vermelho Marfim Intenso } \\
\text { Canela Pastel Vermelho Marfim Nevado }\end{array}$ & $\begin{array}{l}\text { CN.PT.VM.MF.IN } \\
\text { CN.PT.VM.MF.NV }\end{array}$ \\
\hline CC 17I & Canela Pastel Vermelho Marfim Mosaico Macho & CN.PT.VM MF.MS.MC \\
\hline CC 172 & Canela Pastel Vermelho Marfim Mosaico Fêmea & CN.PT.VM.MF.MS.FE \\
\hline CC 173 & Isabelino Pastel Vermelho Intenso & 1S.PT.VM.IN \\
\hline CC 174 & Isabelino Pastel Vermetho Nevado & IS.PT.VM.NV \\
\hline CC 175 & Isabelino Pastel Vermetho Mosaico Macho & IS.PT. VM MS.MC \\
\hline CC 176 & Isabelino Pastel Vermelho Mosaico Fêmea & 1S.PT.VM.MS.FE \\
\hline CC 177 & Is abelino Pastel Vermelho Marfim Intenso & IS.PT.VM.MF.IN \\
\hline CC 178 & Isabelino Pastel Vermetho Marfim Nevado & IS.PT.VM.MF.NV \\
\hline CC 179 & Isabelino Pastel Vermelho Marfim Mosaico Macho & IS.PT.VM MF.MS.MC \\
\hline CC 180 & Isabelino Pastel Vermelho Marfim Mosaico Fêmea & IS.PT.VM.MF.MS.FE \\
\hline CС 181 & Azul Opalino & AZ.OP \\
\hline CC 182 & Azul Opalino Dominante & AZ.OP.DO \\
\hline $\mathrm{CC} 183$ & Verde Opalino Intenso & VD.OP.IN \\
\hline CC 184 & Verde Opalino Nevado & VD.OP.NV \\
\hline CC 185 & Verde Opalino Mosaico Macho & VD.OP.MS.MC \\
\hline CC 186 & Verde Opalino Mosaico Fêmea & VD.OP.MS.FE \\
\hline CC 187 & Verde Opalino Marfim Intenso & VD.OP.MF.1N \\
\hline CC 188 & Verde Opalino Marfim Nevado & VD.OP.MF.NV \\
\hline CC 189 & Verde Opalino Marfim Mosaico Macho & VD.OP.MF.MS.MC \\
\hline CC 190 & Verde Opalino Marfim Mosaico Fêmea & VD.OP.MF.MS.FE \\
\hline CC 191 & Ágata Opalino Prateado & AG.OP.PR \\
\hline CC 192 & Ágata Opalino Prateado Dominante & AG.OP.PR.DO \\
\hline CC 193 & Agata Opalino Amarelo Intenso & AG.OP.AM.IN \\
\hline CC 194 & Agata Opalino Amarelo Nevado & AG.OP.AM.NV \\
\hline CC 195 & Ágata Opalino Amarelo Mosaico Macho & AG.OP.AM.MS.MC \\
\hline CC 196 & Agata Opalino Amarelo Mosaico Fêmea & AG.OP.AM.MS.FE \\
\hline CC 197 & Agata Opalino Amarelo Marfim Intenso & AG.OP.AM.MF.IN \\
\hline CC 198 & Ágata Opalino Amarelo Marfim Nevado & AG.OP.AM.MF.NV \\
\hline СC 199 & Agata Opalino Amarelo Marfim Mosaico Macho & AG.OP.AM.MF.MS.MC \\
\hline CC 200 & Ágata Opalino Amarelo Marfim Mosaico Fêmea & AG.OP.AM.MF.MS.FE \\
\hline CC 201 & Canela Opalino Prateado & CN.OP.PR \\
\hline CC 202 & Canela Opalino Prateado Dominante & CN.OP.PR.DO \\
\hline CC 203 & Canela Opalino Amarelo Intenso & CN.OP.AM.IN \\
\hline CC 204 & Canela Opalino Amarelo Nevado & CN.OP.AM.NV \\
\hline CC 205 & Canela Opalino Amarelo Mosaico Macho & CN.OP.AM.MS.MC \\
\hline CC 206 & Canela Opalino Amarelo Mosaico Fêmea & CN.OP.AM.MS.FE \\
\hline CC 207 & Canela Opalino Amarelo Marfim Intenso & CN.OP.AM.MF.IN \\
\hline CC 208 & Canela Opalino Amareio Marfim Nevado & CN.OP.AM.MF.NV \\
\hline CC 209 & Canela Opalino Amareio Marfim Mosaico Macho & CN.OP.AM.MF.MS.MC \\
\hline CC 210 & Canela Opalino Amareio Marfim Mosaico Fêmea & CN.OP.AM.MF.MS.FE \\
\hline CC 211 & Isabelino Opalino Prateado & 1S.OP.PR \\
\hline CC 212 & Isabelino Opallno Prateado Dominante & 1S.OP.PR.DO \\
\hline CC 213 & Isabelino Opalino Amarelo Intenso & IS.OP.AM.IN \\
\hline CС 214 & Isabelino Opalino Amarclo Nevado & IS.OP.AM.NV \\
\hline CC 215 & Isabelino Opalino Amarclo Mosaico Macho & IS.OP.AM.MS.MC \\
\hline CC 216 & Isabelino Opalino Amarelo Mosaico Femea & IS.OP.AM.MS.FE \\
\hline
\end{tabular}




\begin{tabular}{|c|c|c|}
\hline Codigos: & 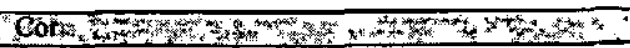 & Abreviacian \\
\hline$\overline{\mathrm{CC}} 217$ & Isabelino Opalino Amarelo Marfim Intenso & IS.OP.AM.MF.IN \\
\hline $\mathrm{CC} 218$ & lsabelino Opalino Amarelo Marfim Nevado & IS.OP.AM.MF.NV \\
\hline CC 219 & lsabelino Opafino Amarelo Marfim Mosaico Macho & IS.OP.AM.MF.MS.MC \\
\hline CC 220 & lsabelino Opalino Amarelo Marfim Mosaico Fêmea & IS.OP.AM.MF.MS.FE \\
\hline CC 221 & Cobre Opal ino Intenso & CB.OP.IN \\
\hline $\mathrm{CC} 222$ & Cobre Opalino Nevado & CB.OP.NV \\
\hline CC 223 & Cobre Opalino Mosajco Macho & CB.OP.MS.MC \\
\hline CC 224 & Cobre Opalino Mosaico Fêmea & CB.OP.MS.FE \\
\hline CC 225 & Cobre Opalino Marfim Intenso & CB.OP.MF.IN \\
\hline CC 226 & Cobre Opalino Marfim Nevado & CB.OP.MF.NV \\
\hline CC 227 & Cobre Opalino Marfim Mosaico Macho & CB.OP.MF.MS.MC \\
\hline CC 228 & Cobre Opalino Marfim Mosaico Fêmea & CB.OP.MF.MS.FE \\
\hline CC 229 & Ágata Opalino Vermelho lntenso & AG.OP.VM.IN \\
\hline CC 230 & Ágata Opalino Vermelho Nevado & AG.OP.VM.NV \\
\hline CC 23I & Ágata Opalino Vermelho Mosaico Macho & AG.OP.VM.MS.MC \\
\hline CC 232 & Ágata Opalino Vermelho Mosaico Fêmea & AG.OP.VM.MS.FE \\
\hline CC 233 & Ágata Opalino Vermelho Marfim Intenso & AG.OP.VM.MF.IN \\
\hline CC 234 & Ágata Opalino Vermelho Marfim Nevado & AG.OP.VM.MF.NV \\
\hline CC 235 & Ágata Opalino Vermelho Marfim Mosaico Macho & AG.OP.VM.MF.MS.MC \\
\hline CC 236 & Ágata Opal ino Vermelho Marfim Mosaico Fêmea & AG.OP.VM.MF.MS.FE \\
\hline CC 237 & Canela Opalino Vermelho Intenso & CN.OP.VM.IN \\
\hline CC 238 & Canela Opalino Vermelho Nevado & CN.OP.VM.NV \\
\hline CC 239 & Canela Opadino Vermelho Mosaico Macho & CN.OP.VM.MS.MC \\
\hline CC 240 & Canela Opalino Vermelho Mosaico Fêmea & CN.OP.VM.MS.FE \\
\hline CC 24I & Canela Opalino Vermelho Marfim Intenso & CN.OP. VM.MF.IN \\
\hline CC 242 & Canela Opalino Vermelho Marfim Nevado & CN.OP.VM.MF.NV \\
\hline CC 243 & Cancia Opalino Vermelho Marfim Mosaico Macho & CN.OP.VM.MF.MS.MC \\
\hline CC 244 & Canela Opalino Vermelho Marfim Mosaico Fêmea & CN.OP.VM.MF.MS.FE \\
\hline CC 245 & Isabelino Opalino Vermelho Intenso & IS.OP.VM.IN \\
\hline CC 246 & Is abelino Opalino Vermelho Nevado & IS.OP.VM.NV \\
\hline CC 247 & Isabelino Opalino Vermelho Mosaico Macho & IS.OP.VM.MS.MC \\
\hline CC 248 & Isabelino Opalino Vermelho Mosaico Fêmea & IS.OP.VM.MS.FE \\
\hline CC 249 & Isabelino Opalino Vermelho Marfim Intenso & IS.OP.VM.MF.IN \\
\hline CC 250 & Isabelino Opalino Vermelho Marfim Nevado & IS.OP.VM.MF.NV \\
\hline $\mathrm{CC} 251$ & Isabelino Opalino Vermelho Marfim Mosaico Macho & IS.OP.VM.MF.MS.MC \\
\hline CC 252 & lsabelino Opalìno Vermelho Marfim Mosaico Fêmea & IS.OP.VM.MF.MS.FE \\
\hline $\mathrm{CC} 253$ & Feo Albino Macho & FE.AL.MC \\
\hline CC 254 & Feo Albino Dominante Macho & FE.AL.DO.MC \\
\hline CC 255 & Feo Lutino Intenso Macho & FE.LU.IN.MC \\
\hline CC 256 & Feo Lutino Nevado Macho & FE.LU.NV.MC \\
\hline CC 257 & Feo Lutino Mosajco Macho & FE.LU.MS.MC \\
\hline CC 258 & Feo Lutino Marfim Intenso Macho & FE.LU.MF.IN.MC \\
\hline CC 259 & Feo Lutino Marfim Nevado Macho & FE.LU.MF.NV.MC \\
\hline CC 260 & Feo Lutino Marfim Mosaico Macho & FE.LU.MF.MS.MC \\
\hline CC 261 & Feo Albino Fêmea & FE.AL.FE \\
\hline CC 262 & Fco Albino Dominante Fêmea & FE.AL.DO.FE \\
\hline CC 263 & Fco Lutino Intenso Fèmea & FE.LU.IN.FE \\
\hline CC 264 & Feo Lutino Nevado Fémea & FE.LU.NV.FE \\
\hline CC 265 & Feo Lutino Mosaico Fêmea & FE.LU.MS.FE \\
\hline CC 266 & Feo Lutino Marfim lntenso Fèmea & FE.LU.MF.IN.FE \\
\hline CC 267 & Feo Lutino Marfim Nevado Fêmea & FE.LU.MF.NV.FE \\
\hline CC 268 & Fco Lutino Marfim Mosaico Fêmea & FE.LU.MF.MS.FE \\
\hline CC 269 & Feo Rubino Intenso Macho & FE.RU.IN.MC \\
\hline CC 270 & Feo Rubino Nevado Macho & FE.RU.NV.MC \\
\hline CC 27! & Feo Rubino Mosaico Macho & FE.RU.MS.MC \\
\hline CC 272 & Feo Rubino Marfim Intenso Macho & FE.RU.MF.IN.MC \\
\hline $\mathrm{CC} 273$ & Feo Rubino Marfim Nevado Macho & FE.RU.MF.NV.MC \\
\hline CC 274 & Feo Rubino Marfim Mosaico Macho & FE.RU.MF.MS.MC \\
\hline CC 275 & Feo Rubino lntenso Fêmea & FE.RU.IN.FE \\
\hline CC 276 & Feo Rubino Nevado Fêmea & FE.RU.NV.FE \\
\hline $\mathrm{CC} 277$ & Feo Rubino Mosaico Fêmea & FE.RU.MS.FE \\
\hline $\mathrm{CC} 278$ & Feo Rubino Marfim Intenso Fèmea & FE.RU.MF.IN.FE \\
\hline CC 279 & Feo Rubino Marfim Nevado Fêmea & FE.RU.MF.NV.FE \\
\hline CC 280 & Feo Rubino Marfim Mosaico Fêmea & FE.RU.MF.MS.FE \\
\hline CC 281 & Acetinado Prateado & AC.PR \\
\hline CC 282 & Acetinado Prateado Dominante & AC.PR.DO \\
\hline CC 283 & Acetinado Amarelo Intenso & AC.AM.IN \\
\hline CC 284 & Acetinado Amarelo Nevado & AC.AM.NV \\
\hline CC 285 & Acetinado Amarelo Mosaico Macho & AC.AM MS.MC \\
\hline CC 286 & Acetinado Amarelo Mosajco Femmea & AC.AM.MS.FE \\
\hline CC 287 & Acetinado Amarelo Marfim Intenso & AC.AM.MF.IN \\
\hline CC 288 & Acetinado Amarelo Marfim Nevado & AC.AM.MF.NV \\
\hline CC 289 & Acetìnado Amarelo Marfim Mosaico & AC.AM MF.MS.M \\
\hline
\end{tabular}




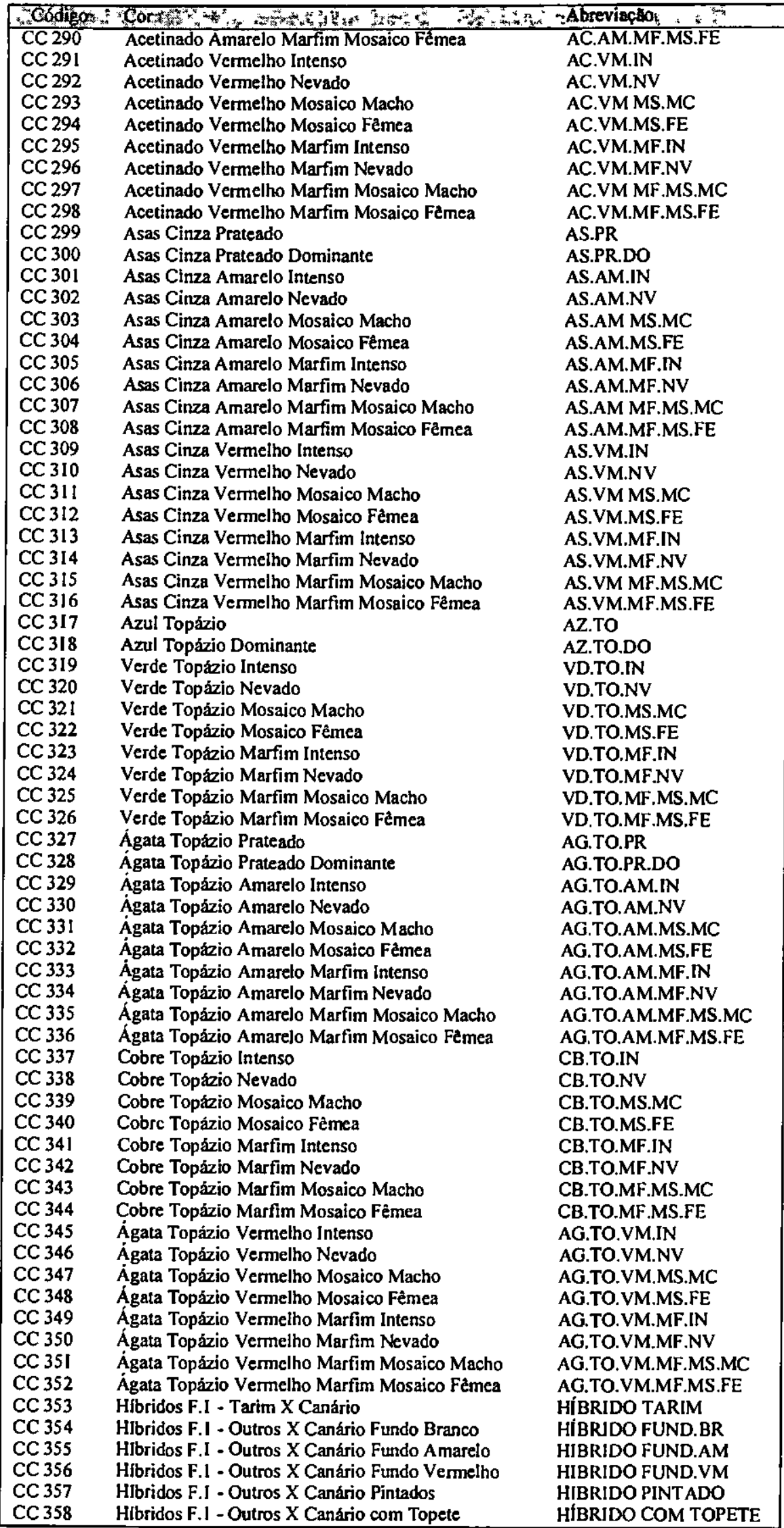


[CLE88] CLEAL, D.M., Heaton, N.O., Knowledge-Based Systems - Implications for HumanComputer Interfaces, Ellis Horwood Limited, 1988.

[COR95] CORES - Clubes Ornitológicos Reunidos do Estado de São Paulo, Revista Técnica Anual, 1995.

[COR96] CORES - Clubes Ornitológicos Reunidos do Estado de São Paulo, Revista Técnica Anual, 1996.

[EPM97] Universidade Federal de São Paulo - Escola Paulista de Medicina, "Padrões de Herança Monogênica" página HTML (http://www.epm.br/ge/genetic/htm), 1997.

[FER88] FERREIRA, A.B.H., Novo Dicionário Básico da Língua Portuguesa, Ed. Nora Fronteira, 1988.

[GAN83] GANE, C., Sarson, T., Análise Estruturada de Sistemas, Livros Técnicos e Cientificos Editora, $1^{\mathbf{a}}$ ed, 1983.

[GIA94] GIARRATANO, J., Riley, G., Expert Systems Principles and Programming. PWS Publishing Company, 1994.

[HUR96] HURTREL, D., “Os Canários Feos", Brasil Ornitológico, FOB - Federação Ornitológica do Brasil, n 23, pp. 14-16, 1996.

[KBS94] US ARMY AI CENTER, "Knowledge-Based Systems (KBS)", página HTML (http://www.pentagon-ai.army.mil/aic/overwatch/papers/KBSInfoPaper.html), 1994.

[KEU] VAN KEULEN, “Color Bred Canaries”, Fotografie: Pieter Van Den Hooven: Zwolle. Holanda.

[KOB96] KOBAYASHI, R., "O Canário Branco", Brasil Ornitológico, FOB - Federação Ornitológica do Brasil, nº 22, pp. 12-17, 1996.

[MAT92] MATTHEW, M.V., The New Canary Handbook, Barron's Educational Series. Inc. 1992.

[NEI92] NEIVA, V., Brenelli, J.P., "Acasalamentos de Canários de Cor", 25" Exposição de Canários e Aves Exóticas", União Ornitológica do Vale do Paraíba, 1992.

[OBJ96] MANUAL DE JULGAMENTO - Canários de Cor, FOB - Federação Ornitológica do Brasil. OBJO - Ordem Brasileira dos Juizes de Ornitologia, Campinas, 1996. 
[OLS96] OLSZEWSKI, A., "The Canary FAQ by Anthony Olszewski", página HTML (http://www.upatsix.com/faq/canary.htm), 1996.

[PRE95] PRESSMAN, R. S., Engenharia de Software, Makron Books, 3ª ed, 1995.

[PUG97] PUGLIESE, J. B., REZENDE, S. O., "Ferramenta Flex para Desenvolvimento de Sistema Baseado em Conhecimento", Notas Didáticas do ICMSC nำ 27, Universidade de São Paulo, 1997.

[RAG92] RAGGET, J., Bains, W., Artificial Intelligence from $A$ to $Z, 1^{\mathrm{a}}$ ed, Chapman \& Hall, 1992.

[ROD93] RODRIGUES, S.R., Monard, M.C., "Sistemas Baseados em Conhecimento Conceitos Fundamentais e Aplicações", Universidade de São Paulo - ICMSC / ILTC, 1993.

[SEI96a] SEIXAS, E., "Os Canários Asas-Cinza", Brasil Ornitológico, FOB - Federação Ornitológica do Brasil, nº 21, pp. 7-11, 1996.

[SEI96b] SEIXAS, E., "Albino - Ser ou não ser", Brasil Ornitológico, FOB - Federação Ornitológica do Brasil, nº 23, pp. 5-7, 1996.

[SEI96c] SEIXAS, E., "Canários Mosaicos - Encontros e Desencontros", Brasil Ornitológico, FOB - Federação Ornitológica do Brasil, nº 21, pp. 70-74, 1996.

[SEI97] SEIXAS, E., Seixas, G., Criação de Canários - A Genética das Cores, $1^{\mathrm{a}}$ ed, 1997.

[SIL87] SILVA, J.L.C., Os Canários de Cor - Genética Aplicada às Mutações, 1987.

[VAR95] VARTANIAN, G., “A Extensa Variabilidade Genética Presente nos Canários", XXIV Exposição de Canários de Cor, Canto e Porte - União de Canaricultores de São José do Rio Preto, 1995.

[WAL87] WALKER, G.B.R., Avon, D., Coulored, Type \& Song Canaries - A Complete Guide to Keeping, Breeding and Showing, Blandford Press, 1987. 